\author{
Universidade de São Paulo \\ Interunidades em Ciência e Engenharia de \\ Materiais \\ Escola de Engenharia de São Carlos \\ Instituto de Física de São Carlos \\ Instituto de Química de São Carlos
}

\title{
Dispositivos LED para polimerização de resinas compostas dentais: comparação com outras fontes de luz.
}

\author{
Igor Studart Medeiros
}

Dissertação apresentada à área de Interunidades em Ciência e Engenharia de Materiais, da Universidade de São Paulo, como parte dos requisitos para obtenção do título de Mestre em Ciência e Engenharia de Materiais.

\section{Orientador: Professor Doutor Vanderlei Salvador Bagnato.}

São Carlos 


\section{DEDICATÓRIA}

Aos meus pais, Sérgio e Celina, pelo apoio incondicional em todos os momentos de minha caminhada. 


\section{AGRADECIMENTOS}

Agradecimentos póstumos aos meus avós, Filomeno, Cleide e Sérgio, pelo exemplo de vida.

À minha avó Marlene, por toda a apreciação e apoio.

À minha irmã, Lucila, pela alegre e dinâmica incentivadora.

Aos meus tios, primos e demais familiares, especialmente ao Paulo e Eliana, pelo apoio pessoal e crença na minha dedicação.

À Milena, minha namorada, pelo companheirismo e amor dedicados durante este período.

À Dra. Adeliani Campos, pelo real incentivo à carreira acadêmica e científica.

Aos meus amigos, Carlos e Cláudia, pela colaboração nas áreas exatas e, sobretudo, pelos devaneios com respeito à formação pessoal.

Aos meus amigos, Daniel, Kílvia, Joatan, Elvira, Flávio e Newton peb acolhimento e composição do time cearense. 
Aos amigos Cléber e Lino pela não linearidade mas discussões.

Às minhas amigas de sala Aparecida, Carla, Débora e Juliana pelas ajudas mesmo nos dias de mauthumor.

Às amigas de profissão Cristina, Rosane, Carla, Augusto e Paulo pela colaboração e incentivo.

A todos os colegas e amigos de Fortaleza que participaram e contribuíram com a minha formação pessoal.

Aos técnicos, secretárias e participantes, Marcel, Aparecida, Brás, Ruy, Gilberto, Evaldo, Gláucia e Isabel pela organização e prestatividade.

Aos professores da Faculdade de Odontologia da Universidade Federal do Ceará pela participação na minha formação básica.

A todos os professores das disciplinas que direto ou indiretamente contribuíram para a realização deste trabalho.

Aos Professores Carlos Cruz e Geraldo Vaz pela colaboração e pelos debates científicos.

Ao Professor Vanderlei pela oportunidade. 
À Fapesp pela infraestrutura disposta e apoio através da bolsa de estudo.

Aos coordenadores do curso de Interunidade pela persistência em obter uma pós-graduação integradora de várias áreas do conhecimento.

À Universidade de São Paulo e a UNESP pelas portas sempre abertas e serviços prestados à ciência brasileira e mundial. 


\section{ÍNDICE}

Capítulo I: Introdução e Objetivos 1

Capítulo II: Considerações gerais sobre os aparelhos e caracterização do dispositivo à base de LEDs azuis 9

Capítulo III: Estudo da microdureza em função da espessura e tempo de exposição ............................................................................................................................... 25

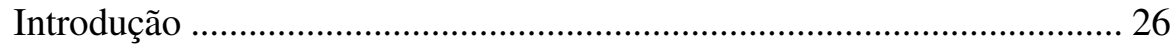

Materiais e Métodos …............................................................................... 28

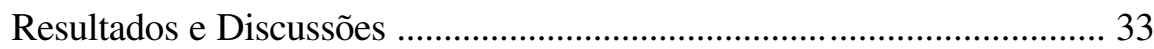

Capítulo IV - Análise térmica com resolução temporal durante a irradiação pelas fontes de luz ........................................................................................................................... 44

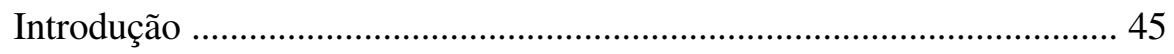

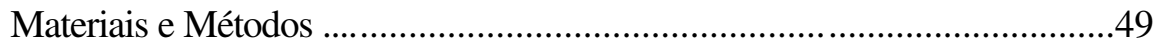

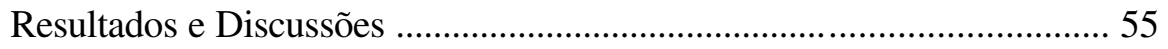

Capítulo V - Variação de propriedades mecânicas das resinas compostas com a exposição a agentes químicos e análise em microscopia eletrônica de

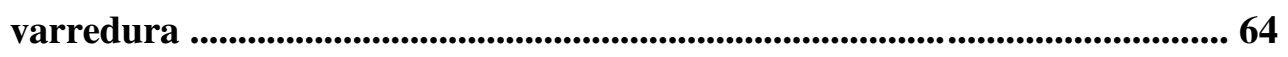

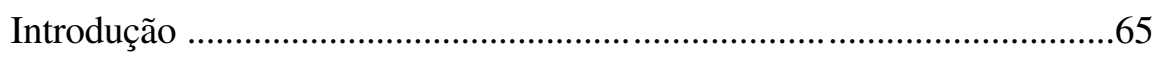

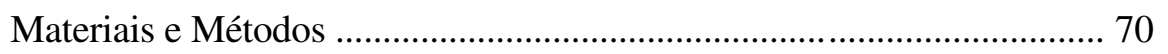

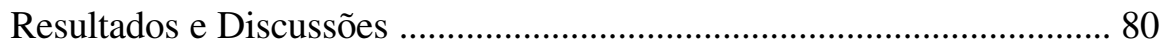

Capítulo VI - Discussões gerais, conclusões e sugestões para trabalhos

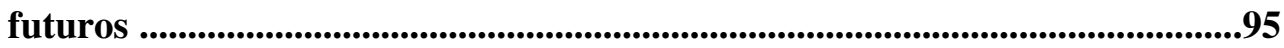

Referências Bibliográficas .......................................................................... 101

Apêndice A ............................................................................................... 109

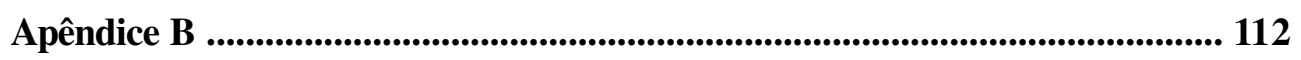




\section{ÍNDICE DE FIGURAS}

Figura 2.1 - Aparelho 200 R (K\&M, São Carlos, Brasil).................................... 13

Figura 2.2 - Figura esquemática do laser de argônio........................................... 15

Figura 2.3 - Mostrando o feixe emergente sendo conduzido por espelhos até o acoplamento com a fibra óptica.................................................................... 16

Figura 2.4 - Mostrando o feixe sendo conduzido pela fibra óptica flexível projetando em anteparo metálico 16

Figura 2.5 - Unidade LED. Verificar que a parte ativa corresponde somente a região central envolvida por resina transparente.

Figura 2.6- Mostrando o arranjo interno das seis unidades LEDs na ponteira com o dispositivo desligado. 20

Figura 2.7 - Mostrando o arranjo interno das seis unidades LEDs na ponteira com o dispositivo ligado. 20

Figura 2.8 - Mostrando o espectro de emissão das fontes de luz para polimerização de resinas compostas dentais e a banda de absorção do principal fotoiniciador presente nas resinas compostas. 22

Figura 2.9 - Gráfico mostrando o espectro de emissão do fotopolimerizador convencional e sua decomposição em gaussianas................................................. 23

Figura 3.1 - Microdurômetro - mhp 160 Microhardness Tester........................... 30

Figura 3.2 - Observação através da objetiva do microscópio de uma área central do espécime.

Figura 3.3 - Aplicação do identador na região central da amostra........................ 31

Figura 3.4 Gráfico de microdureza Vickers no topo ...................................... 34

Figura 3.5 - Gráfico de microdureza Vickers na base de espécimes de 0,7 mm de espessura..................................................................................................... 35

Figura 3.6 - Gráfico de microdureza Vickers na base de espécimes de 2,0 mm de espessura. 35

Fig 3.7 - Gráfico geral dos valores de microdureza Vickers 36

Figura 3.8 - Gráfico mostrando a taxa de redução da microdureza Vickers em função da espessura do espécime quando irradiada pelo aparelho de cura convencional por $40 \mathrm{~s}$.. 40 
Figura 3.9 - Gráfico mostrando a taxa de redução da microdureza Vickers em função da espessura do espécime quando irradiada pelo dispositivo de cura à base de LEDs por $40 \mathrm{~s}$ 41

Figura 3.10 - Gráfico mostrando a taxa de redução da intensidade de luz em função da profundidade da resina composta quando irradiada pela lâmpada convencional (à esquerda) e com o dispositivo LED (à direita)........................... 42

Figura 4.1 - Termistor adaptado no interior da câmara pulpar............................. 50

Figura 4.2 - Figura esquemática para demonstrar o posicionamento do termistor no interior da câmara e da cavidade Classe V... 50

Figura 4.3 - Desenho esquemático do aparato experimental para simular as condições térmicas da cavidade oral.. 51

Figura 4.4 - Representação esquemática da irradiação com as fontes de luz....... 53

Figura 4.5 - Representação gráfica da variação térmica intrapulpar. 56

Figura 4.6 - Gráfico de um dos dentes estudados, apresentando o perfil de aquecimento e resfriamento obtido em cada grupo............................................. 58

Figura 4.7- Gráfico que determina os perfis de resfriamento 59

Figura 4.8 - Gráfico indicando a variação de temperatura durante a polimerização com o termistor localizado na base da restauração 62

Figura 5.1 - Figura esquemática do ensaio de tração diametral........................... 75

Figura 5.2 - Amostras fraturadas coladas em porta amostra.............................. 77

Figura 5.3 - Equipamento de "sputtering" ....................................................... 78

Figura 5.4 - Amostras após a metalização com fina camada de ouro.................. 78

Figura 5.5 - Figura mostrando a coluna de elétrons do MEV ............................... 79

Figura 5.6 - Figura mostrando o controlador e microprocessador do MEV............. 79

Figura 5.7 - Gráfico de MHV, no topo, em função da fonte de luz..................... 83

Figura 5.8 - Gráfico de MHV, na base, em função da fonte de luz....................... 83

Figura 5.9 - Gráfico de MHV, no topo, em função do meio de armazenagem.... 84

Figura 5.10 - Gráfico de MHV, na base, em função do meio de armazenagem...84 
Figura 5.11 - Valores médios de tensão em função da fonte de luz..................... 89

Figura 5.12 - Valores médios de tensão em função do meio de armazenagem.... 89

Figura 5.13 - Fotografia do fragmento polimerizado com o dispositivo LED em exposição de 60 segundos, em aumento de 15 x

Figura 5.14 - Fotografia do fragmento polimerizado com o dispositivo LED em exposição de 60 segundos, armazenado em álcool $50 \%$, em aumento de 15 x... 93

Figura 5.15 - Fotografia do fragmento polimerizado com o dispositivo LED em exposição de 60 segundos, grupo controle, em aumento de $2000 \mathrm{x}$. 94

Figura 5.16 - Fotografia do fragmento polimerizado com o dispositivo LED em exposição de 60 segundos, armazenado em álcool, em aumento de 2000 x...........94

Figura 5.17 - Fotografia do fragmento polimerizado com o laser de argônio, grupo controle, em aumento de $2000 \mathrm{x}$. 94

Figura 5.18 - Fotografia do fragmento polimerizado com o aparelho convencional, armazenado em ácido acético, em aumento de 2000 x.................. 94 


\section{ÍNDICE DE TABELAS}

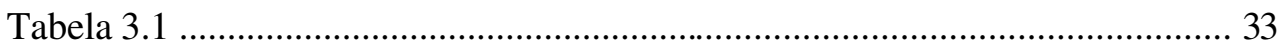

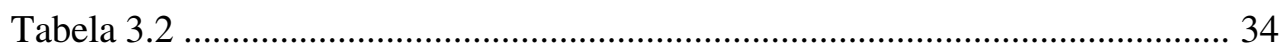

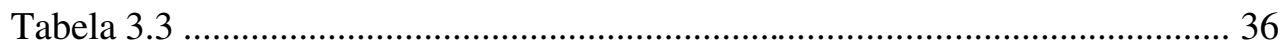

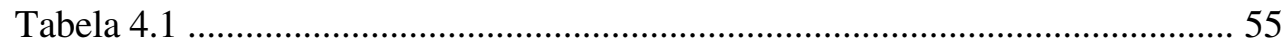

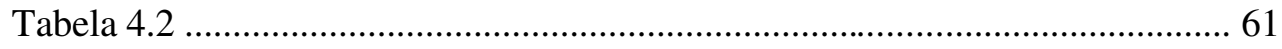

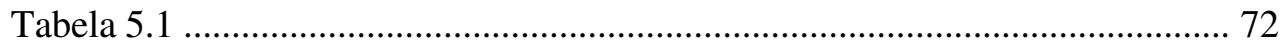

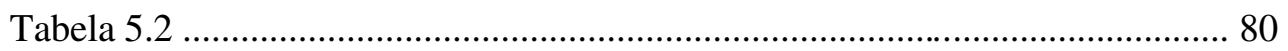

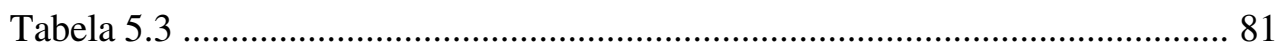

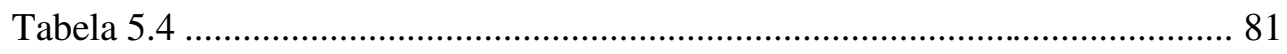

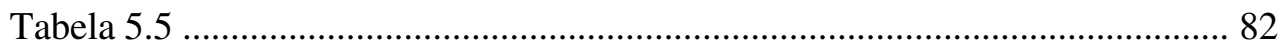

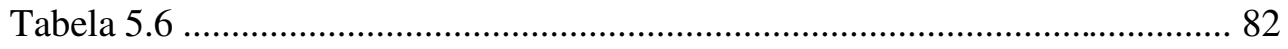

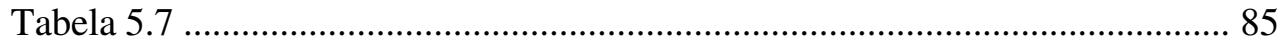

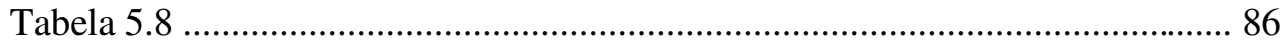

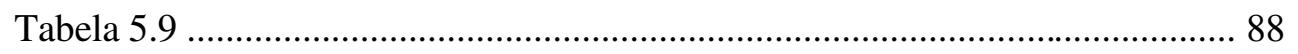

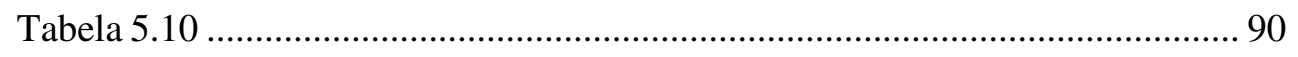

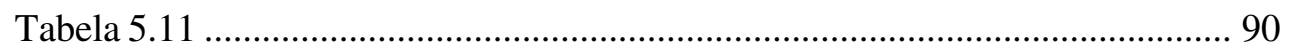




\title{
LISTA DE ABREVIATURAS E SÍMBOLOS
}

\author{
$\mathrm{m}$ - metro \\ cm - centímetro \\ mm- milímetro \\ $\mu \mathrm{m}-$ micrômetro \\ nm - nanômetro \\ LED - light emitting diode - diodo emissor de luz \\ $\mathrm{s}$ - segundo \\ W - watts \\ $\mathrm{mW}$ - miliwatts (unidade de potência) \\ mA- miliampere \\ $\Delta \mathrm{T}$ - variação de temperatura \\ ${ }^{\mathrm{o}} \mathrm{C}$ - graus Celsius
}




\section{RESUMO}

Muito se tem feito para a melhoria das resinas compostas polimerizadas através de luz visível. A maioria dos estudos, no entanto, restringe-se apenas às fontes de luz convencionais e pouco tem sido feito no sentido de viabilizar novas fontes, introduzindo novas tecnologias nesta área do conhecimento. No intuito de desenvolver novos dispositivos de geração de luz para a polimerização das resinas compostas dentais, o Grupo de Óptica tem sido um dos pioneiros mundiais no desenvolvimento e caracterização de dispositivos utilizando LEDs azuis. Neste trabalho, verificou-se a viabilidade de um novo dispositivo à base de LEDs azuis, executando-se uma análise comparativa com o aparelho de polimerização convencional e o laser de argônio. Para a validação deste novo dispositivo, executaram-se testes de microdureza Vickers em espécimes de resina composta de diferentes espessuras, expostos a diferentes tempos de irradiação. Foi executado o teste de análise térmica, com resolução temporal, durante o processo de exposição à luz para polimerização com finalidade de verificar a variação térmica pulpar em terceiros molares recém-extraídos. Em seguida, determinou-se a variação das propriedades de microdureza e resistência à tração diametral após armazenagem em alguns agentes químicos encontrados na cavidade oral. Os resultados demonstraram que o dispositivo à base de LEDs apresenta-se viável para polimerização de compósitos dentais, com algumas vantagens em relação a outras fontes de luz utilizadas para esta finalidade. 


\begin{abstract}
The improvement of composite resins polymerization through visible light has been an important research topic. The majority of the studies, however, are restricted only to the conventional light sources and little has been made to viable new sources, introducing new technologies in this area of the knowledge. In intention to develop new light sources for dental composite resins polymerization, the Optics Group is one of the pioneers in the development and characterization of devices, using blue LEDs for this purpose. In this work, it was verified the viability of a new device based in blue LEDs, executing a comparative analysis with the conventional polymerization device and the argon laser. For the validation of this new device, tests of microhardness Vickers in composite resin specimens had been executed using different thickness, exposed at different times of irradiation. It was executed the test of thermal analysis during the process of exposure to the polymerization light, to verify the thermal variation in the pulpal chambers of third molars caries free. After that, it was determined the variation of microhardness and diametral tensile strength properties when composite specimens were storaged in chemical agents found in the oral cavity. The results have demonstrated that the LEDs based device presented is viable for polymerization of dental composites with some advantages in relation to other used light sources.
\end{abstract}




\title{
Dispositivos LED para polimerização de
}

\section{resinas compost as dent ais: comparação com}

\author{
out ras f ont es de luz.
}




\section{INTRODUÇÃO}

A premissa estética tem sido um dos principais apelos da odontologia moderna. Neste sentido, as resinas compostas estão sendo utilizadas em larga escala, pois permitem o restabelecimento da funcionalidade mastigatória e fonética, além da estética natural e harmoniosa dos dentes quando utilizada em suas indicações.

Nos últimos anos, muitos aperfeiçoamentos foram obtidos nas resinas compostas dentais incluindo: a utilização de variados tamanhos e composições das partículas cerâmicas, o desenvolvimento de novos compostos orgânicos para compor a base orgânica, possibilitar menor contração de polimerização e boas características mecânicas e de manuseio, a obtenção de novos tons para uma estética mais adequada, o desenvolvimento de novos fotoiniciadores passando de um sistema de cura química para o sistema de cura através de luz visível, entre outros. [9] [14] [37] [47]

As resinas compostas dentais atuais são processadas através da polimerização ativada por luz visível e apresentam uma série de benefícios como: maior variedade nas tonalidades de matiz, valor e saturação, melhor estabilidade de cor, tempo de trabalho mais adequado, melhores propriedades mecânicas, entre outros aspectos.[47] Apesar de poderem ser trabalhadas e depois polimerizadas, existem alguns problemas, principalmente em relação à contração de polimerização que se exacerba quando a velocidade de presa é aumentada e ao grau de conversão de monômeros em polímeros no interior do corpo resinoso quando se utiliza incremento mais espesso. Em regiões do material onde a cura não é efetiva, o resultado clínico pode culminar em sensibilidade pós-operatória, infiltração marginal e fracasso da restauração. [15][33] 
A polimerização dos compósitos dentais é um dos principais tópicos de estudos na odontologia mundial, em especial na área de dentística restauradora, pois é fator primordial para o êxito das restaurações diretas de resinas compostas.

As características e propriedades finais do material dependem diretamente do grau de cura e poderão variar de acordo com a quantidade de ligações cruzadas estabelecidas entre as cadeias da matriz orgânica, influenciadas, dentre outros fatores, pela a composição da resina composta, região do espectro emitido pela fonte de luz, intensidade de luz, distância fonte de luz - resina composta, tempo de irradiação, etc. $[10][17][26][40][48]$

O processo de polimerização das resinas atuais ocorre através da absorção da luz visível pela molécula fotoiniciadora que na maior parte das resinas compostas é a canforquinona. Quando a canforquinona é excitada por comprimentos de onda adequados passa de seu estado fundamental para um estado tripleto excitado *. Uma combinação da canforquinona excitada com uma molécula intermediária gera um complexo excitado que promoverá a conversão de ambos em radicais livres, iniciando o processo de polimerização por adição de monômeros, através de ligações químicas cruzadas entre as cadeias. Neste processo, a luz interage com o fotoiniciador e funciona como fonte de energia necessária para promover a excitação destas moléculas, bem como para a formação das ligações químicas entre os monômeros resinosos durante o processo de cura. [10][43][47]

O estado tripleto excitado que ocorre durante o processo de absorção de luz pelos fotoiniciadores, referido no parágrafo acima, indica o estado de spin dos elétrons do complexo, modificando o estado de reatividade.

Um dos maiores problemas das restaurações de resina composta é a infiltração marginal. A falta de um selamento marginal permite a entrada de bactérias na interface 
dente-restauração promovendo problemas como recidiva de cárie, sensibilidade devido aos ácidos orgânicos liberados pelas bactérias acidogênicas e, portanto, determinando a falha da restauração. Parte deste problema pode ser relacionado ao método de cura e a fonte de luz utilizada.

$\mathrm{Na}$ literatura, algumas técnicas diferenciadas de polimerização das resinas compostas, têm sido descritas, utilizando abordagens que modificam a técnica tradicional para redução da contração de polimerização. Este método consiste na utilização de fonte de luz convencional (lâmpada de filamento associada a um filtro) com intensidade de luz reduzida nos primeiros segundos, seguido de polimerização com intensidade de luz equivalente a aproximadamente $500 \mathrm{~mW} / \mathrm{cm}^{2}$. Através destes trabalhos, verificou-se uma redução da contração de cura das resinas sem comprometer a conversão dos monômeros resinosos, apresentando-se semelhante para ambas as técnicas. [26][31][41]

Relacionado ao grau de cura obtido por uma polimerização efetiva do material está a estabilidade da matriz polimérica e a formação de produtos que resultam de sua degradação. Estudos têm demonstrado que a resina composta dental é susceptível a vários modos de degradação química. [2][8][30][32][42][44][45].

Existem indícios de que a degradação química da resina composta se dá principalmente por difusão de moléculas e íons dos monômeros resinosos que não reagiram no processo de cura e por hidrólise do agente silano que faz a união da carga com a matriz orgânica da resina composta. [8][44][45]

A degradação química juntamente com a cura não efetiva das resinas compostas dentais podem comprometer a estabilidade de cor dos compósitos através da incorporação de corantes nas microporosidades da matriz polimérica. Tem-se 
Dispositivos LED para polimerização de resinas compostas dentais comparação com outras fontes de luz. Capítulo I: Introdução e Objetivos

demonstrado que um maior grau de cura permite uma menor descoloração do compósito. [24]

Outro problema, bastante relatado na literatura, refere-se à variação de temperatura na câmara pulpar induzida durante a exposição da resina composta à fonte de luz responsável pela fotoiniciação do processo de cura. [1][12][27][39]

ZACH e COHEN, em 1965, fizeram um estudo histológico dos danos causados na polpa, devido ao aquecimento de elementos dentais de macacos da espécie Macaca rhesus, e verificaram que a partir de $5,5^{\circ} \mathrm{C}$ de variação térmica, parte dos dentes estudados apresentaram inflamação irreversível. Portanto, a obtenção de uma fonte de luz que apresente eficiência na ativação do processo de cura, aliada a um comportamento que não leve a polpa a danos térmicos, é imprescindível.[53]

Verifica-se que a polimerização adequada das resinas compostas dentais é condição determinante para obtermos o melhor desempenho do material em suas propriedades físicas e mecânicas. Para isso, o estudo de novas fontes de luz para ativação do processo de polimerização é um tópico de grande importância.

Os LEDs (light emitting diodes ) surgem para as mais diversas aplicações e apresentam características importantes que os tornam atrativos para utilização na polimerização de resinas compostas dentais. Dentre os aspectos interessantes podemos citar: a relação tensão/intensidade de corrente favorável para a utilização em baixas tensões permitindo a evolução para aparelhos alimentados por bateria, a vida útil de milhares de horas sem perda de rendimento, a emissão espectral em coincidência com o fotoiniciador das resinas compostas dentais não necessitando do uso de filtros ópticos resultando em processo de ativação bastante eficiente, uma relação custo/benefício favor ável entre outros. 
Neste trabalho, estudaram-se as características de cura para um dispositivo de polimerização de resinas compostas à base de LEDS azuis. Para a validação do novo dispositivo, realizaram-se experimentos comparativos entre o aparelho para polimerização convencional (lâmpada halógena), o laser de argônio, e o dispositivo à base de LEDS azuis. Este trabalho corresponde à segunda dissertação do nosso grupo de pesquisa com o objetivo de viabilizar dispositivos à base de LED para cura de resinas compostas dentais.

Inicialmente, realizou-se a montagem do dispositivo experimental e várias medidas para a sua caracterização. Em seguida, realizou-se um experimento de microdureza Vickers da resina composta polimerizada em função da fonte de luz, da espessura do espécime e do tempo de exposição à luz do dispositivo à base de LEDS azuis para determinação dos tempos de utilização em cada espessura variando até $2 \mathrm{~mm}$ de espessura.

Realizou-se um experimento de análise térmica com resolução temporal durante o processo de exposição à fonte de luz para polimerização utilizando os três diferentes dispositivos objeto de estudo. Neste ensaio, utilizaram-se termistores de alta precisão fixados na câmara pulpar de terceiros-molares humanos para a verificação do calor transferido à polpa durante o processo de exposição à luz.

Executou-se ensaio de microdureza Vickers e tração diametral de espécimes de resina composta submetidos a agentes químicos normalmente encontrados na cavidade oral: ácido acético, ácido propiônico, solução aquosa de álcool etílico $50 \%$ e água destilada. Através deste experimento, observamos a estabilidade química adquirida pela resina composta após a polimerização com cada fonte de luz e a redução de algumas propriedades mecânicas. 
Através destes ensaios, pode-se obter boas informações a respeito da dinâmica de cura, a verificação comparativa de algumas propriedades químicas e mecânicas obtidas com as três fontes de luz objeto de estudo, bem como a determinação de alguns parâmetros para o uso clínico do dispositivo à base de LEDS. 


\section{OBJETIVOS GERAIS}

Viabilizar um novo dispositivo à base de LEDS azuis para a polimerização de resinas compostas dentais.

\section{OBJETIVOS ESPECÍFICOS}

Estabelecer uma análise comparativa entre o novo dispositivo à base de LEDs azuis, o aparelho convencional e o laser de argônio, através de:

- Estudo da microdureza Vickers de espécimes de resina composta dental em função da espessura do espécime, tempo de irradiação e da fonte de luz.

- Análise térmica com resolução temporal durante a irradiação com as fontes de luz, dentro da câmara pulpar de terceiros molares humanos recém extraídos.

- Estudo da variação das propriedades mecânicas de microdureza Vickers e de resistência à tração diametral de resinas compostas dentais, após imersão em agentes químicos.

- Análise macroscópica e microscópica da fratura com auxílio de microscopia eletrônica de varredura. 


\title{
Dispositivos LED para polimerização de
}

\section{resinas compost as dent ais: comparação}

\author{
com outras f ont es de luz.
}

Capítulo II: Considerações gerais sobre os aparelhos e caracterização do

dispositivo à base de LEDs azuis 


\section{CONSIDERACÕES GERAIS SOBRE OS APARELHOS E}

\section{CARACTERIZAÇÃO DO DISPOSITIVO À BASE DE LEDS AZUIS}

Muito se tem feito para a melhoria das resinas compostas polimerizadas através de luz visível. A maioria dos estudos, no entanto, restringe-se apenas às fontes de luz convencionais e pouco tem sido feito no sentido de viabilizar novas fontes, introduzindo novas tecnologias neste ramo do conhecimento. No intuito de desenvolver novos dispositivos de geração de luz para a polimerização das resinas compostas dentais, o Grupo de Óptica é um dos pioneiros mundiais no desenvolvimento e caracterização de dispositivos utilizando LEDs azuis com esta finalidade.

Neste capítulo, faremos uma revisão das fontes de luz para polimerização de resinas compostas dentais destacando a montagem e caracterização do dispositivo à base de LEDs azuis, estabelecendo comparações entre as demais fontes utilizadas nos experimentos.

Podemos citar como fontes de luz utilizadas para a cura de resinas compostas dentais: o fotopolimerizador convencional, na maioria das vezes, lâmpada halógena com filtro; o laser de argônio (comprimento de onda de 488 nanômetros) no modo contínuo e pulsado; lâmpadas de xenônio (arco de plasma); e, mais recentemente, dispositivos à base de LEDs azuis. 


\section{Fotopolimerizador comvencional - lâmpada de filamento associada a filtro}

A unidade mais utilizada nos consultórios odontológicos para a cura das resinas compostas dentais são os fotopolimerizadores convencionais. Os aparelhos convencionais apresentam basicamente uma lâmpada de filamento, filtro, sistema de refrigeração e fibras ópticas para a entrega da luz. Estes componentes variam de uma unidade para outra de acordo com o fabricante.

Os aparelhos convencionais são dispositivos que apresentam uma lâmpada halógena (25 a 75 Watts), com filtro que permite a passagem em banda larga da região azul do espectro, com uma potência média de saída em torno de 200 a 400 $\mathrm{mW}$. Este processo de obtenção de luz azul pelos dispositivos comuns exibe perda demasiada de energia. Além disso, o feixe de luz emergente carrega desnecessariamente uma grande quantidade de luz fora da região espectral de interesse para a cura. [23]

O princípio de emissão é caracterizado por um filamento de tungstênio, que se encontra dentro do bulbo com gás inerte e flúor, aquecido emitindo luz branca e muita radiação na região do infravermelho, responsável pelo calor. A luz produzida pelo filamento aquecido é direcionada para o filtro através de um refletor. Apesar destes dispositivos apresentarem sistemas de refrigeração, a degradação do bulbo, refletor, filtro e fibra óptica ocorre devido às altas temperaturas produzidas, gerando modificações no espectro de emissão e diminuição de potência de saída com o tempo de uso. Em consequiência, há uma diminuição da efetividade de polimerização com o uso do aparelho. [5][11] 
Os primeiros aparelhos para polimerização, utilizando luz visível, apresentavam a lâmpada na base do aparelho. A luz era entregue ao material através de fibras ópticas flexíveis, tinha-se um dispositivo de bancada. No entanto, havia o rompimento gradativo devido à fragilidade nas fibras ópticas resultando em diminuição da potência de saída.

Esse sistema foi então substituído por um sistema de polimerização de mão, onde a lâmpada, o filtro e o sistema de refrigeração estão presentes no dispositivo de mão e a luz é entregue ao material com auxílio de fibras ópticas rígidas.

A lâmpada dos dispositivos de polimerização convencional tem um tempo de vida relativamente curto, cerca de 100 horas, por isso recomenda-se a reposição da lâmpada e do filtro regularmente, para evitar a perda de potência do aparelho e, conseqüentemente, a falha prematura das restaurações de resina composta em virtude de uma polimerização ineficiente do material. [5][10]

O aparelho convencional, utilizado na realização deste trabalho, foi o modelo 200 R, da empresa K\&M (São Carlos, Brasil). Este aparelho apresentou potência de saída de $350 \mathrm{~mW}$ e uma intensidade de $700 \mathrm{~mW} / \mathrm{cm}^{2}$. O aparelho descrito apresentase na figura 2.1 
Dispositivos LED para polimerização de resinas compostas dentais: comparação com outras fontes de luz.

Capítulo II: Considerações gerais sobre os aparelhos e caracterização do dispositivo à base de LEDs azuis

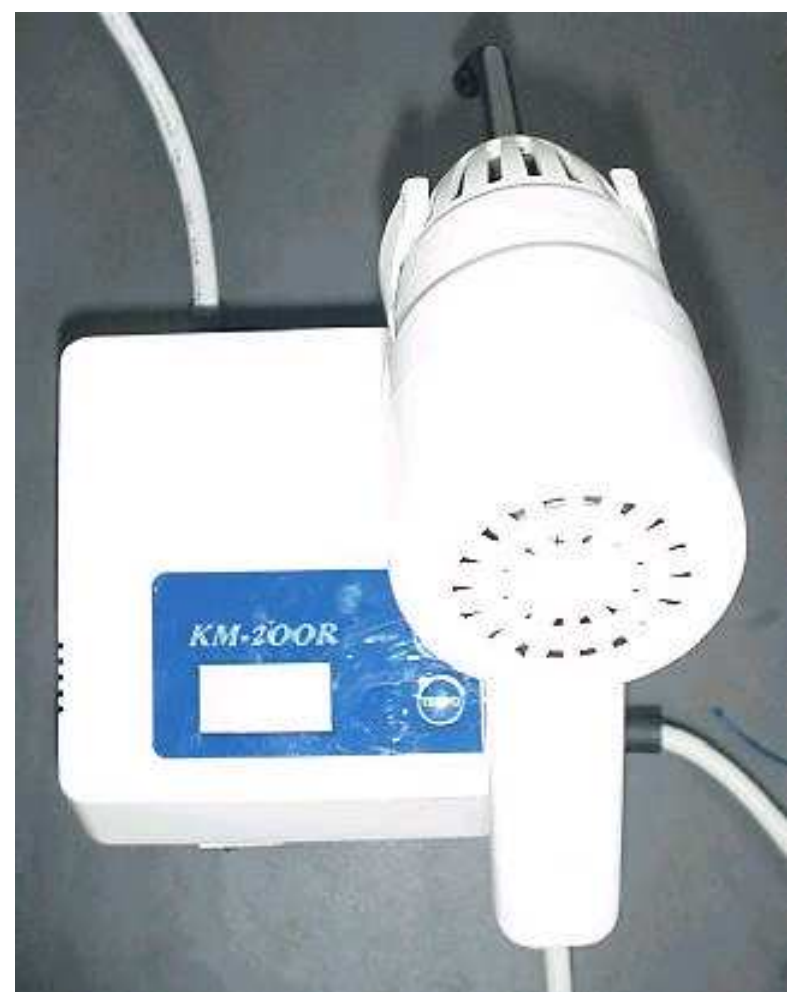

Figura 2.1 - Aparelho 200 R (K\&M, São Carlos, Brasil). 


\section{Laser de Argônio}

O laser é um dispositivo que apresenta inúmeras utilizações: instrumento para realização de estudos ópticos avançados, monitoração de poluição do ar, monitoração de poluição dos solos, utilização na área da saúde através de bisturis e fotocoaguladores, instrumentos para remoção de tecidos moles e duros, estímulos fotoquímicos de analgesia e antiinflamação, além de sua utilidade para processamento de materiais: ferramenta para fundição e usinagem de cerâmicas e metais, incluindo a polimerização de resinas compostas dentais.

A palavra laser é um acrônimo que significa Light Amplification by Stimulated Emission of Radiation, que na língua portuguesa se traduz como Amplificação da Luz por Emissão Estimulada de Radiação. O laser utilizado para a polimerização das resinas compostas dentais apresenta como meio ativo o gás argônio, por isso chamado: laser de argônio.

O laser de argônio apresenta um modo de emissão diferente do aparelho convencional. O dispositivo é composto por uma ampola de gás argônio, contido em uma cavidade óptica, que apresenta dois espelhos: um totalmente refletor e outro parcialmente refletor. Os espelhos são colocados em lados opostos da cavidade para permitir a ressonância das ondas eletromagnéticas. Ao acionar o dispositivo, o gás de argônio recebe uma descarga elétrica levando os átomos de argônio para um estado excitado. Ao retornarem para o estado fundamental os átomos emitem fótons que são capturados pelos espelhos e ressonam na cavidade óptica amplificando a produção de fótons gêmeos. Quando o feixe atinge altas potências passa do espelho semi-refletor 
para a região externa a cavidade óptica. O desenho esquemático para uma melhor compreensão está apresentado na figura 2.2.

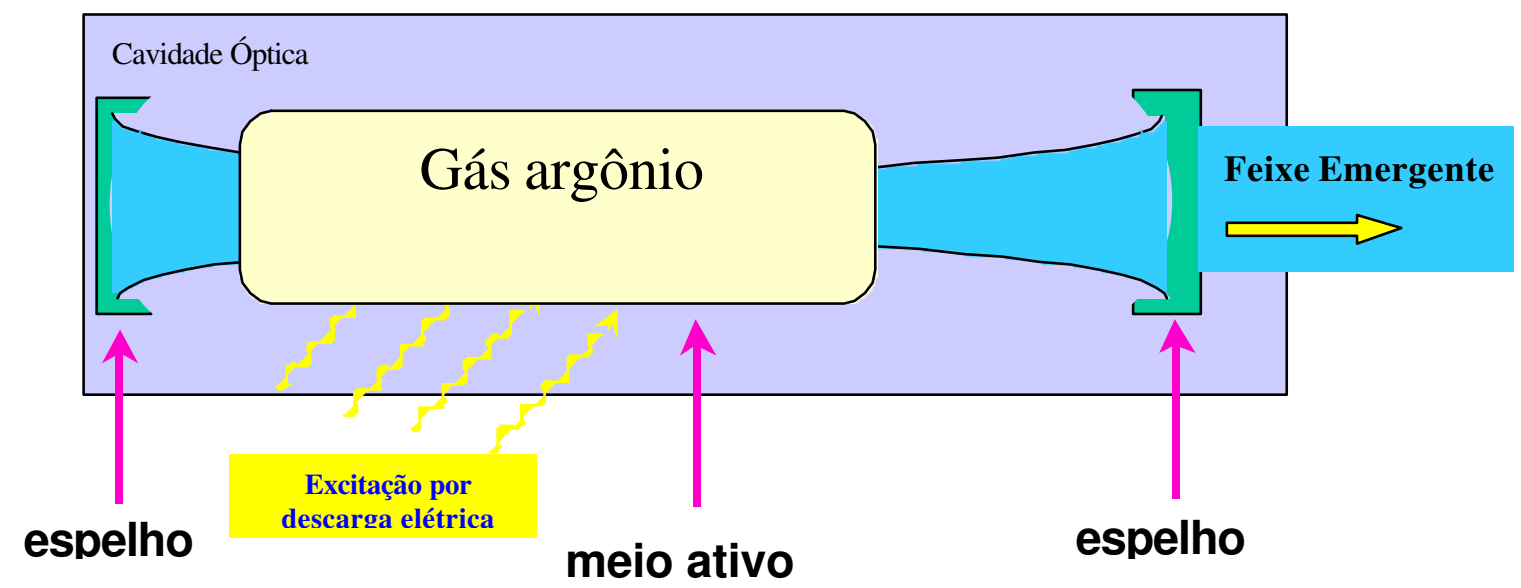

Figura 2.2 - Figura esquemática do laser de argônio.

O resultado da emissão estimulada é um feixe de luz com características peculiares especiais diferentes da luz comum. As principais características do feixe laser são: coerência, colimação e monocromaticidade.

O laser de argônio tem sido aplicado para polimerização de resina compostas dentais, permitindo uma redução entre 50 e 75 porcento no tempo de cura, através de seu feixe altamente colimado, e altíssima concentração de energia, num comprimento de onda bastante favorável para excitação do fotoiniciador da resina composta (linha $488 \mathrm{~nm})$. As propriedades de microdureza obtidas são semelhantes ou melhores que o aparelho de polimerização convencional. [12][34][49]

O laser de argônio utilizado nos experimentos foi o INNOVA 100 (Coherent, EUA), utilizando a entrega de luz através de fibra óptica flexível em potências de 
Dispositivos LED para polimerização de resinas compostas dentais: comparação com outras fontes de luz. Capítulo II: Considerações gerais sobre os aparelhos e caracterização do dispositivo à base de LEDs azuis

saída de $300 \mathrm{~mW}$ e $500 \mathrm{~mW}$, com um diâmetro de feixe de saída de $8 \mathrm{~mm}$ (Figuras 2.3 e 2.4$)$

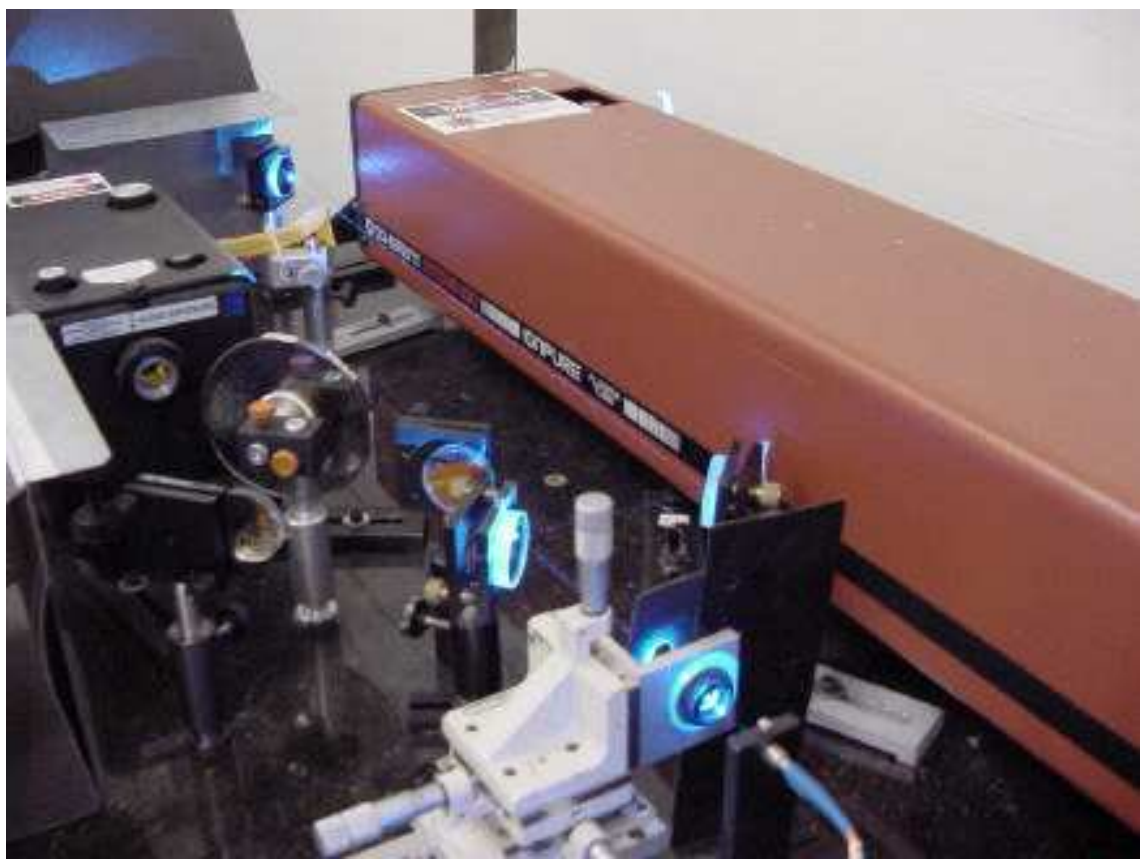

Figura 2.3 - Mostrando o feixe emergente sendo conduzido por espelhos até o acoplamento com a fibra óptica

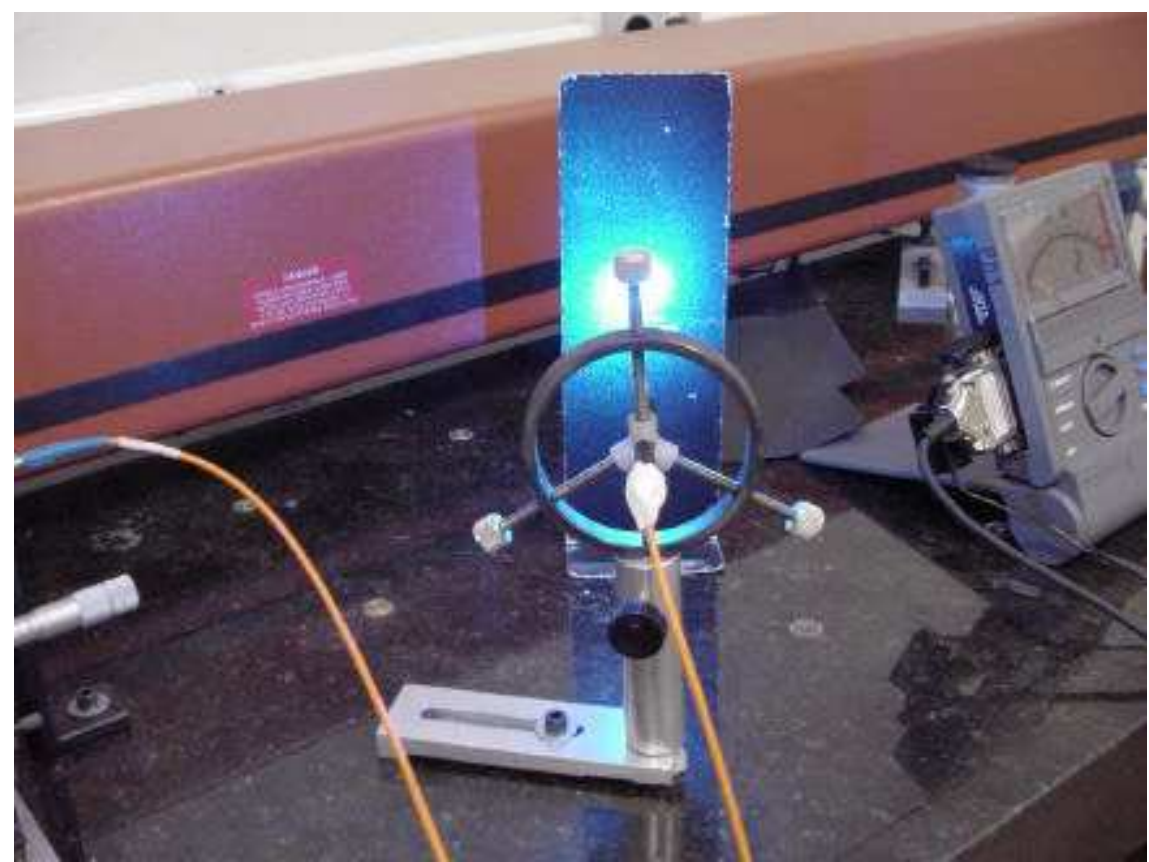

Figura 2.4 - Mostrando o feixe sendo conduzido pela fibra óptica flexível projetando em anteparo metálico 


\section{$\underline{\text { LED ( light emitting diode) - diodo emissor de luz }}$}

O LED (light emitting diode) azul é um diodo composto por um semicondutor de In - Ga - N (Índio - Gálio - Nitrogênio), que apresenta um modo de emissão diferente dos dispositivos comentados anteriormente. $\mathrm{O}$ semicondutor apresenta características de condução eletrônica intermediárias, ou seja, necessita da aplicação de uma tensão suficientemente alta para vencer a barreira de energia e, a partir de então, apresentar condução elétrica.

O LED apresenta uma junção do tipo n-p, isto é, apresenta de um lado um semicondutor do tipo n, doador de elétrons e de outro lado um semicondutor do tipo p, rico em buracos receptores de elétrons. Quando a tensão aplicada é capaz de vencer a barreira de energia do GAP (intervalo proibido), ocorre a passagem dos elétrons da camada de valência para a camada de condução, gerando um fluxo de elétrons e buracos. Na junção n-p ocorre o decaimento dos elétrons, através da recombinação do par elétron - buraco, ocorrendo a emissão de fótons. Portanto, o espectro de emissão do LED está diretamente relacionado aos materiais que compõem o semicondutor.

Os LEDs azuis (Nichia Chem. Indust. Ltd, Anan, Japan), utilizados nesta pesquisa, apresentam o espectro de emissão em banda estreita com o pico de emissão em comprimentos de onda em torno de $470 \mathrm{~nm}$. Nesta região do espectro está contido o principal pico de absorção do fotoiniciador das resinas compostas dentais, a canforquinona, não sendo requerido o uso de filtros. Esta pureza espectral permite um aproveitamento total da luz emitida, diferentemente do ocorrido com o fotopolimerizador convencional. [36][50] 
Uma das vantagens oferecidas pelo dispositivo LED é o baixo consumo de corrente elétrica, devido à própria característica da curva tensão versus intensidade de corrente, inerente aos semicondutores. [28]

Os LEDs azuis apresentam potência individual de 5 a $10 \mathrm{~mW}$ e, por isso, os dispositivos para a cura de resina compostas são montados com arranjo de vários LEDs azuis. [21][25][28][35][46][50]

Os LEDs apresentam uma longa vida útil que depende diretamente da ensão e intensidade de corrente aplicados no semicondutor e, se utilizado de acordo com o regime de tensão/intensidade otimizado, poderá ter vida útil de milhares de horas sem perda de rendimento. [51] 


\section{Montagem e caracterização do dispositivo de cura à base de LEDs azuis}

Para a confecção da ponteira, com a finalidade de polimerização de resinas compostas, utilizando como fontes de luz unidades LED (ight emitting diode, Nichia ltd, Japan) disponíveis comercialmente, fez-se necessário o desgaste do material que envolve o diodo. $\mathrm{O}$ desgaste foi feito com auxílio de fresa para desgaste de resinas acrílicas, adaptado à peça reta do motor de baixa rotação. A unidade LED está em detalhes na figura 2.5 .

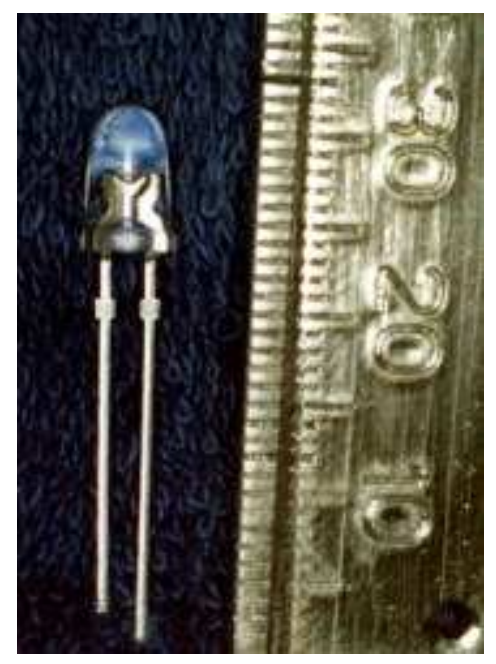

Figura 2.5 - Unidade LED. Verificar que a parte ativa corresponde somente a região central envolvida por resina transparente.

Com um total de seis LEDs desgastados, verificou-se a adaptação destes em um cilindro metálico de $8 \mathrm{~mm}$ de diâmetro interno. Após esta etapa, cada um dos LEDs foi soldado em fios elétricos apropriados e foram ligados em série e adaptados a um modulador de tensão e corrente elétrica. [28]

Os seis LEDs foram novamente adaptados à ponteira circular e inclusos em resina epóxica transparente para fixação definitiva no interior da ponteira. 
O arranjo foi alimentado por uma fonte (6218A, Hewlett Packard, USA), na qual foi possível variar a corrente elétrica e a tensão. A corrente foi fixada em $55 \mathrm{~mA}$ (miliampére). A potência foi aferida em três repetições utilizando dois medidores de potência (Fieldmaster, Coherente, USA) que indicou uma média de $50 \mathrm{~mW}$. Esse protótipo fornece uma intensidade de luz de, aproximadamente, $100 \mathrm{~mW} / \mathrm{cm}^{2}$ na porção central do feixe emitido. $\mathrm{O}$ arranjo pode ser verificado nas figuras 2.6 e 2.7:
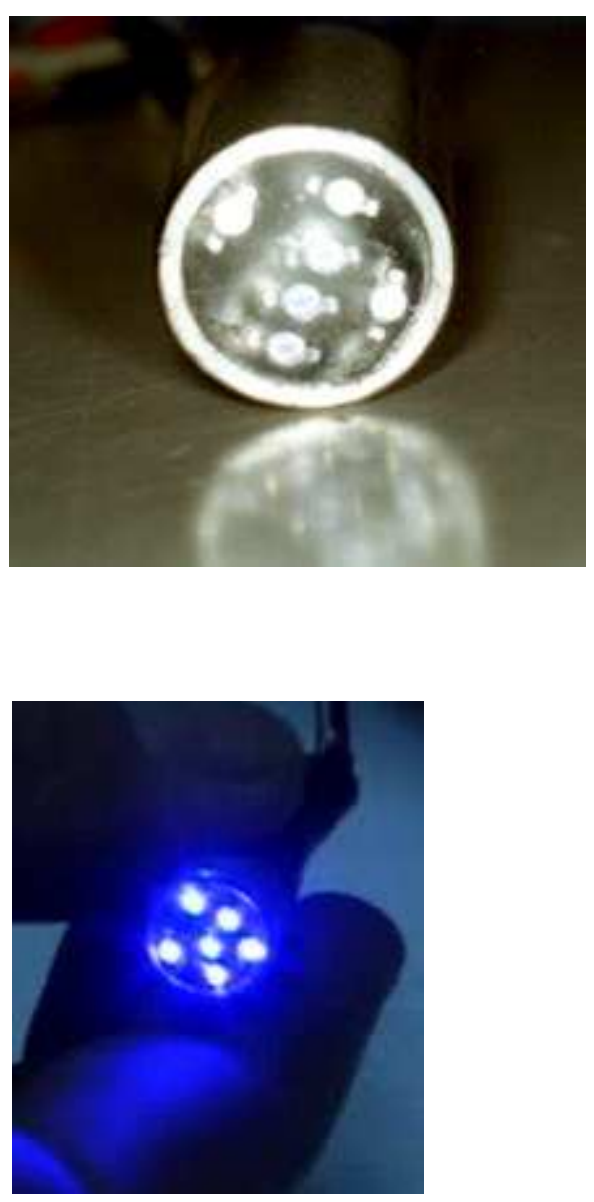

Figura 2.6- Mostrando o arranjo interno das seis unidades LEDs na ponteira com o dispositivo desligado.
Figura 2.7 - Mostrando o arranjo interno das seis unidades LEDs na ponteira com o dispositivo ligado. 
O espectro de emissão do dispositivo à base de LEDs azuis foi obtido em um espectrofotômetro, composto por um monocromador e por uma fotomultiplicadora. O monocromador separa a luz em cada intervalo de freqüência emitida pelo dispositivo e a intensidade correspondente a cada frequiência é determinada através da fotomultiplicadora.

Utilizando este método, obtivemos a curva de emissão indicativa do dispositivo experimental à base de LEDs, do fotopolimerizador convencional à base de lâmpada halógena com filtro (200 R, K\&M, São Carlos, Brasil) utilizado nos testes desenvolvidos nesse trabalho e do laser de argônio (Innova 100, Coherent, USA), operando na linha 488 nanômetros. Para um critério comparativo, na região espectral hachurada (eixo x) está o pico de absorção do principal fotoiniciador das resinas compostas, a canforquinona. Os espectros de emissão estão esquematizados na figura 2.8. 


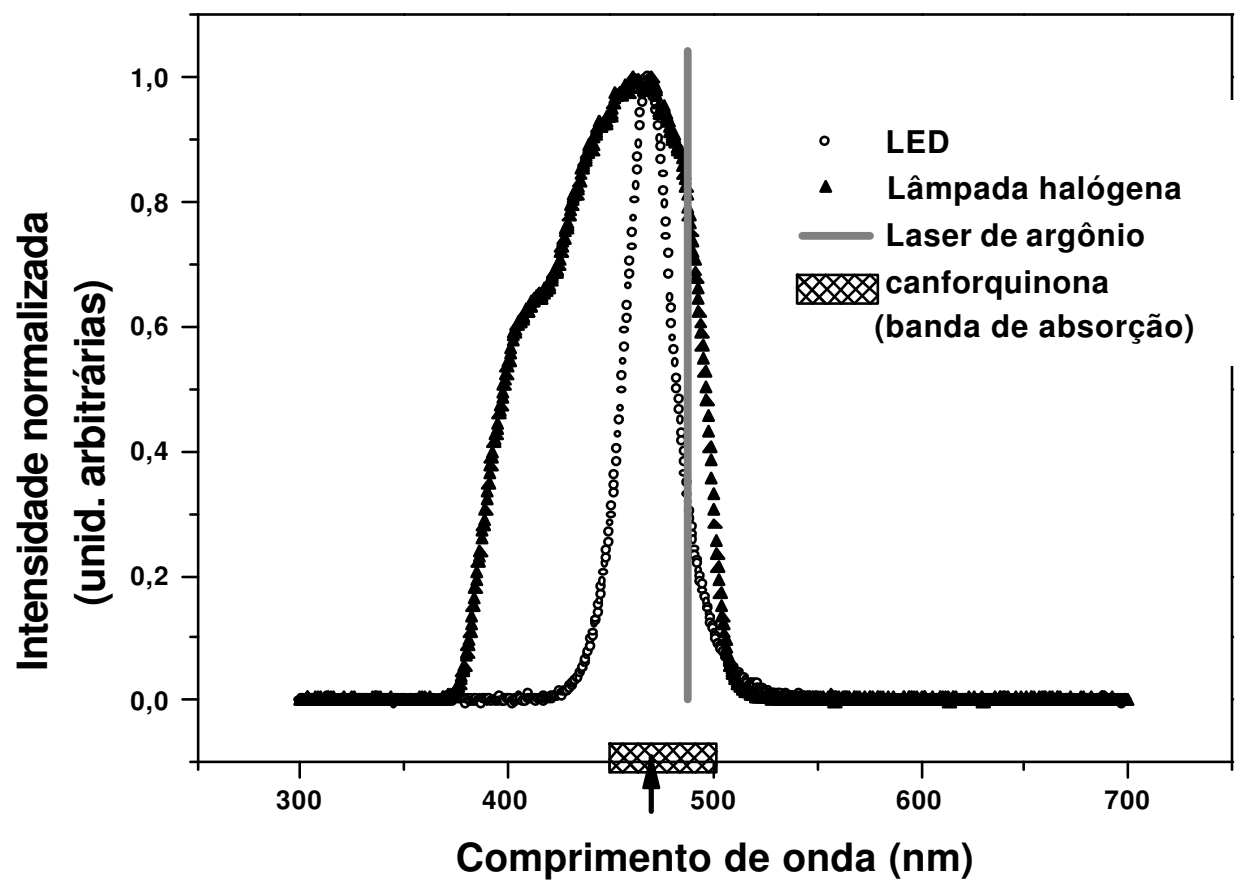

Figura 2.8 - Mostrando o espectro de emissão das fontes de luz para polimerização de resinas compostas dentais e a banda de absorção do principal fotoiniciador presente nas resinas compostas.

A figura 2.8 demonstra o espectro de emissão para a lâmpada halógena convencional e para o dispositivo experimental à base de LEDs, usado neste trabalho, bem como uma linha vertical que representa a linha de emissão do laser de argônio $(488 \mathrm{~nm})$. Além do fato de a luz produzida pela lâmpada halógena passar por um filtro dielétrico, muitos comprimentos de onda desnecessários, localizados fora da faixa espectral adequada para fotoiniciação, estão presentes na luz emitida. O laser difere da luz comum por suas propriedades como: monocromaticidade, coerência e colimação, resultando numa emissão de feixe de única cor com grande concentração de energia.

Os LEDs produzem uma luz divergente e não coerente, assim como a lâmpada halógena, no entanto, apresentam um estreito espectro de emissão. Através 
do gráfico podemos verificar que o espectro de emissão do dispositivo à base de LEDs coincide com a região de pico de absorção da canforquinona (região hachurada no eixo $\mathrm{x}$ ). A pureza espectral do dispositivo em torno de $470 \mathrm{~nm}$ permite a sua utilização para polimerização de materiais odontológicos fotopolimerizáveis, que apresentam a canforquinona como principal fotoiniciador.

O principal problema evidenciado, inicialmente, pelo dispositivo experimental à base de LEDs é a reduzida potência. Para uma melhor avaliação e comparação com o fotopolimerizador convencional, executamos uma decomposição da curva de emissão do aparelho convencional em curvas gaussianas de $30 \mathrm{~nm}$ de largura de banda (figura 2.9)

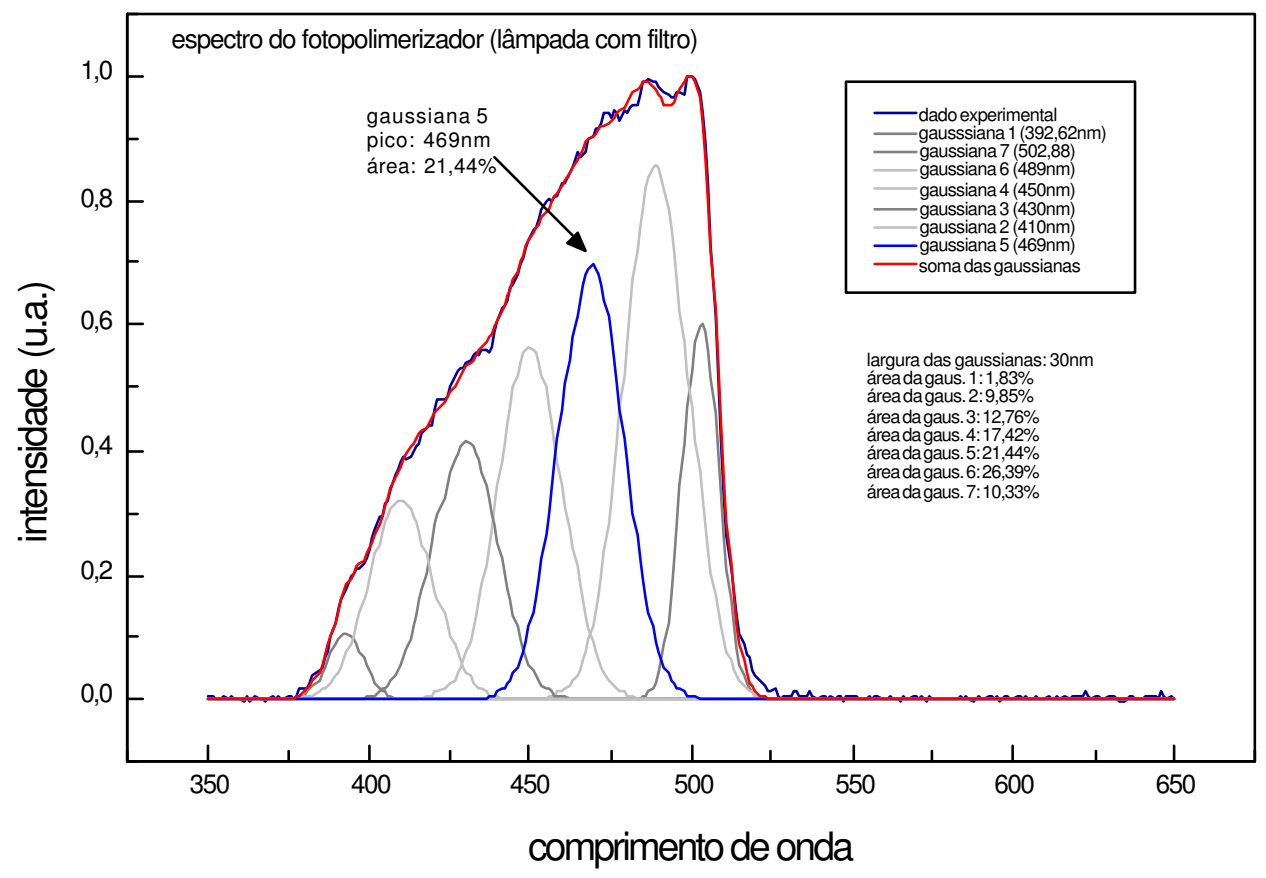

Figura 2.9 - Gráfico mostrando o espectro de emissão do fotopolimerizador convencional e sua decomposição em gaussianas. 
A curva do espectro de emissão da lâmpada com filtro foi decomposta em sete gaussianas. A gaussiana 5 corresponde à região de emissão do dispositivo à base de LEDs. Através da integral desta gaussiana, obtemos a área que corresponde a porcentagem de energia emitida nesta região do espectro, equivalente a $21,4 \%$ da energia total

O aparelho convencional de polimerização, utilizado neste trabalho, foi o 200 R (K\&M, São Carlos, Brasil) que apresenta uma lâmpada halógena que após a colocação do filtro emite uma potência média de $350 \mathrm{~mW}$ na região do espectro indicada no gráfico acima. Podemos determinar que a potência emitida na região de pico de absorção de canforquinona (gaussiana 5, em azul no gráfico) é o equivalente a $75 \mathrm{~mW}$, o restante da potência emitida pouco contribui de fato para o processo de fotoiniciação da canforquinona.

O laser de argônio, por apresentar a característica de monocromaticidade, apresenta toda a energia emitida no comprimento de onda de $488 \mathrm{~nm}$, encontrando-se dentro da região espectral favorável para a cura de resinas compostas. Esse fator permite a utilização do laser em períodos de irradiação menores que os dispositivos convencionais. 


\title{
Dispositivos LED para polimerização
}

\author{
de resinas compost as dent ais:
}

comparação com out ras f ont es de luz.

Capítulo III: Estudo da microdureza em função da espessura e tempo de

exposição. 


\section{INTRODUÇÃO}

O desenvolvimento dos compostos dos materiais como os componentes da matriz orgânica, tipos de partículas e cores, tem sido constante, entretanto, pouco se tem feito a respeito dos dispositivos para polimerização. Além do aparelho convencional que utiliza lâmpada halógena, o laser de argônio e a lâmpada de xenônio (arco de plasma), mais recentemente novos tipos de dispositivo à base de LEDs (light emitting diode) estão começando a ser propostos. $[21][25][28][35][46][50]$

Apesar das vantagens apresentadas pelas resinas compostas polimerizáveis, a profundidade de polimerização desses materiais é diretamente afetada por fatores relacionados à fonte de luz: intensidade de luz irradiada e espectro da luz emitido; e fatores relacionados à técnica: tempo de exposição, espessura do incremento, distância fonte de luz - material, entre outros. [10][40][48]

A dureza na superfície irradiada não pode ser considerada indicação da qualidade de polimerização no interior da restauração. A luz incidente no material é bastante absorvida pelos fotoiniciadores e espalhada pelas partículas cerâmicas, nos primeiros milímetros do material. As técnicas de polimerização indicam a inserção de incrementos de até $2,0 \mathrm{~mm}$ de espessura para permitir uma quantidade de energia suficiente para a formação de ligações cruzadas entre as cadeias no interior do material. [15][33][47][48]

Para comparar a eficiência de polimerização, de diferentes fontes de luz como:o laser de argônio, a lâmpada halógena e o dispositivo à base de LEDs a avaliação da microdureza em diferentes profundidades é um importante teste. [22] 
Dispositivos LED para polimerização de resinas compostas dentais: comparação com outras fontes de luz. Capítulo III: Estudo da microdureza em função da espessura e tempo de exposição

YEARN (1985) publicou uma revisão de literatura sobre os três principais métodos de determinação da profundidade de polimerização de resinas compostas: teste de raspagem, teste de dureza e grau de conversão. O teste de raspagem, segundo o autor, é um teste simples de ser realizado, porém não oferece indicação da qualidade de polimerização em nenhum ponto do interior da resina composta. $\mathrm{O}$ teste de dureza superficial, realizado em intervalos ao longo do comprimento do corpo de prova confeccionado em resina composta, tem sido empregado para determinar a profundidade de polimerização do material. Os métodos de dureza Barcol, Vickers e Knoop podem ser utilizados para avaliar a dureza das resinas compostas. Quanto ao teste de conversão, existem dois métodos principais para avaliação, segundo o autor: a espectroscopia de mú ltipla reflexão interna e a espectroscopia Raman. Estas técnicas são capazes de determinar, quantitativamente, o número de grupos metacrilato presentes na resina composta antes e depois do processo de polimerização ou da quantidade de duplas ligações presentes na resina composta. Esses dois últimos métodos são considerados complexos e inviáveis para medidas de rotina. Como conclusão final, o autor relatou que o teste de dureza realizado em corpos de prova de resina composta, confeccionados em matrizes metálcas, proporciona um método conveniente e eficaz de determinação da profundidade de polimerização. [52]

Neste capítulo, apresenta-se um estudo sistemático para a comparação da microdureza Vickers, obtida em espécimes polimerizados com as três diferentes fontes de luz, para determinar uma relação de tempo de exposição e profundidade de polimerização para o dispositivo experimental à base de LEDs e sua perspectiva para aplicações clínicas. 


\section{MATERIAIS E MÉTODOS}

\section{Preparação das amostras}

Utilizamos, neste experimento, matrizes de aço inoxidável com cilindros de 8 (oito) $\mathrm{mm}$ de diâmetro em duas profundidades: $0,7 \mathrm{~mm}$ e $2,0 \mathrm{~mm}$. Na base de parte cilíndrica, um recorte de tira de poliéster foi acomodada para permitir uma maior lisura na superfície oposta à iluminada.

A resina composta (Z-100, cor A3, <3M do Brasil $>$ ) foi inserida e acomodada em uma só camada e, sobre esta, foi colocada uma matriz de poliéster. Outra placa metálica homogênea e lisa foi sobreposta a todo o sistema pressionando-o mecanicamente, aplicando uma tensão equivalente para todos os espécimes e permitindo uma maior padronização de espessura dos espécimes.

Cada espécime foi polimerizado individualmente, confeccionando-se um total de 125 espécimes de resina composta (Z-100 <3M>, cor A3, lote OHK 2003-03) nas duas espessuras $(0,7 \mathrm{~mm}$ e 2,0 mm), dividida nos seguintes grupos:

- Grupo I - fotopolimerizador convencional - espécimes de resina composta curados com lâmpada halógena (fotopolimerizador convencional $<200 \mathrm{R}, \mathrm{K} \& \mathrm{M}$, Brasil>) por um período de 40 segundos com potência aproximada de $350 \mathrm{~mW}$ e intensidade de $700 \mathrm{~mW} / \mathrm{cm}^{2}$;

- Grupo II - Laser de argônio (linha 488 nm) - as amostras foram curadas por um período de 10 segundos com laser de argônio (INNOVA 100, Coherent, EUA), potência de $500 \mathrm{~mW}$ e $1 \mathrm{~W} / \mathrm{cm}^{2}$ de intensidade; 
- Grupo III - Dispositivo à base de LEDs azuis - as amostras foram curadas por um período de 20, 30, 40, 60 e 90 segundos divididas em 5 (cinco) subgrupos IIIa, III-b, III-c, III-d e III-e, respectivamente. O dispositivo à base de LEDs possui uma potência média de $50 \mathrm{~mW}$ e intensidade aproximada de $100 \mathrm{~mW} / \mathrm{cm}^{2}$.

A exposição da resina composta às fontes de luz foi executada com a ponteira do dispositivo em contato com a superfície de resina composta, protegida com uma tira de poliéster. Esta técnica não foi executada quanto à exposição ao laser de argônio, pois a determinação do diâmetro do feixe é dada pela regulação da distância fibra óptica - resina composta. O diâmetro de saída de feixe, dos aparelhos, foi padronizado em $8 \mathrm{~mm}$.

Em um estudo preliminar piloto, verificou-se que, para os espécimes de 0,7 mm de espessura, a microdureza atingiu um "platô" quando exposta a $60 \mathrm{~s}$ de irradiação pelo dispositivo à base de LEDs e, por este motivo, descartamos o grupo III-e que propunha tempo de exposição de $90 \mathrm{~s}$. Além disso, para os espécimes de 2,0 mm de espessura a utilização do dispositivo à base de LEDs em período de exposição de $20 \mathrm{~s}$ foi insuficiente para determinação da microdureza na face oposta à iluminação e este grupo foi eliminado das análises.

Para uma melhor caracterização e comparação da eficiência de polimerização da resina composta curada com os três aparelhos supracitados, executamos um estudo da microdureza Vickers da superfície iluminada e da face oposta à iluminação nas espessuras de $0,7 \mathrm{~mm}$ e $2,0 \mathrm{~mm}$. 


\section{$\underline{\text { Análise comparativa da Microdureza Vickers }}$}

Cada grupo de espécimes foi cuidadosamente retirado do recipiente, com auxílio de uma pinça clínica, e foi verificada a remoção completa da matriz de poliéster das duas faces do espécime, com auxílio de sonda exploradora $n^{0} 5$. Os espécimes foram mantidos em recipiente escuro para proteger da luz, durante 48 horas.

Posicionamos o espécime de resina composta no Microdurômetro <mhp 160 Microhardness Tester> e, com auxílio da lente de aumento, determinamos uma área central do espécime para receber as marcas do penetrador. $\mathrm{O}$ microdurômetro utilizado está apresentado na figura 3.1

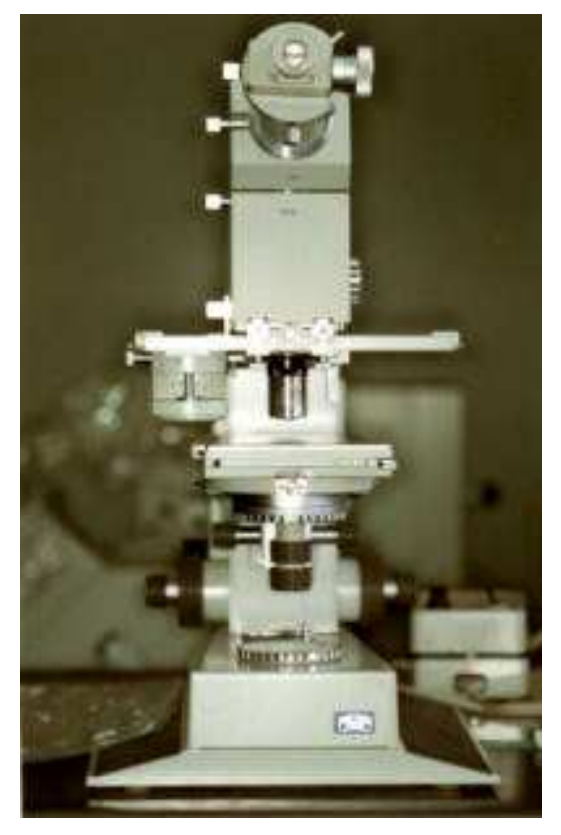

Figura 3.1 - Microdurômetro - mhp 160 Microhardness Tester 
Confeccionamos um total de cinco amostras para cada grupo supracitado, e em cada superfície foram feitas três penetrações utilizando uma carga equivalente a uma massa de 50 gramas por 30 segundos.

A marca obtida pelo penetrador foi identificada e obtivemos as médias das diagonais que foram submetidas à seguinte fórmula matemática para obtenção do número de dureza Vickers:

$$
\mathrm{MHV}=(1854,4 * \mathrm{P}) \div \mathrm{d}^{2}\left(\mathrm{Kg} / \mathrm{mm}^{2}\right)
$$

A busca pela região central do espécime e a aplicação do identador estão representados nas figuras 3.2 e 3.3 :
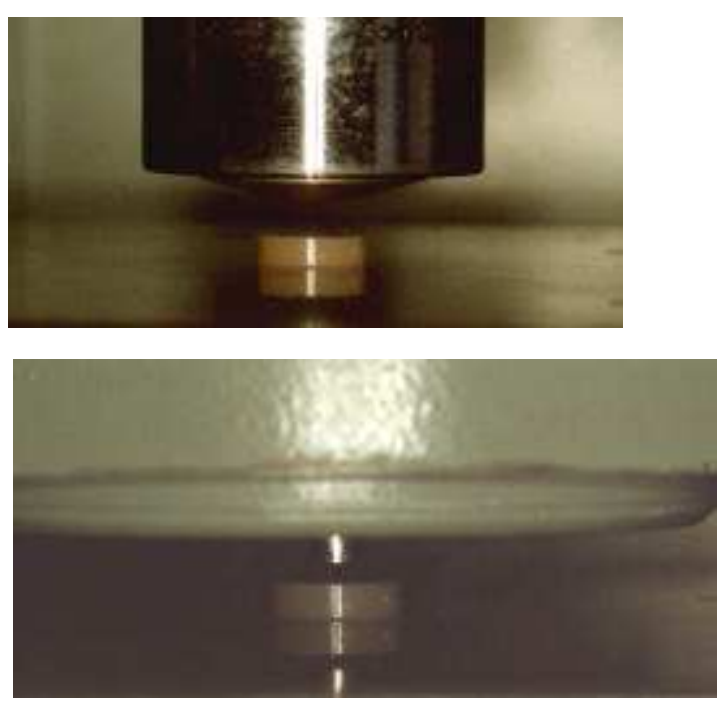

Figura 3.2 - Observação através da objetiva do microscópio de uma área central do espécime.

Verificou-se o valor de dureza Vickers para a face diretamente iluminada (superfície de topo) e também para a face oposta à iluminação (base), para estabelecer a eficiência da cura em função da espessura do espécime e tempo de exposição. 
Dispositivos LED para polimerização de resinas compostas dentais: comparação com outras fontes de luz.

Capítulo III: Estudo da microdureza em função da espessura e tempo de exposição

Os valores de microdureza obtidos foram analisados estatisticamente

utilizando o teste ANOVA para análise de variância, em seguida o teste de Tukey com grau de significância de 5\%. 


\section{RESULTADOS E DISCUSSÕES}

A média da microdureza Vickers obtida na superfície diretamente irradiada (topo) e na superfície oposta (base) em espécimes de $0,7 \mathrm{~mm}$ e $2,0 \mathrm{~mm}$, polimerizados com as três fontes de luz, estão representados nas tabelas 3.1 e 3.2, e em forma de gráficos nas figuras 3.4, 3.5, 3.6 e 3.7.

Tabela 3.1

\begin{tabular}{|c|c|c|c|c|}
\hline \multicolumn{5}{|c|}{ Tabela dos valores médios MHV na base } \\
\hline \multirow[t]{2}{*}{ GRUPO } & \multicolumn{2}{|c|}{ 0,7 MM } & \multicolumn{2}{|c|}{$2,0 \mathrm{MM}$} \\
\hline & MÉDIA & $\begin{array}{l}\text { Desvio } \\
\text { Padrão }\end{array}$ & MÉDIA & $\begin{array}{l}\text { Desvio } \\
\text { Padrão }\end{array}$ \\
\hline $\begin{array}{c}\text { G-I } \\
\text { Lâmpada } \\
\text { Halógena } \\
(40 \mathrm{~s})\end{array}$ & 110,4 & 2,9 & 106,3 & 6,9 \\
\hline $\begin{array}{c}\text { G-II } \\
\text { Laser de } \\
\text { Argônio } \\
(10 \mathrm{~s})\end{array}$ & 111,7 & 5,9 & 106,3 & 7,3 \\
\hline $\begin{array}{l}\text { G-IIIa } \\
\text { LED } \\
20 \mathrm{~s}\end{array}$ & 94,2 & 2,9 & -- & -- \\
\hline $\begin{array}{l}\text { G-IIIb } \\
\text { LED } \\
30 \mathrm{~s}\end{array}$ & 96,3 & 4,2 & 89,0 & 2,7 \\
\hline $\begin{array}{c}\text { G-IIIc } \\
\text { LED } \\
40 \mathrm{~s}\end{array}$ & 104,4 & 3,4 & 101,3 & 3,7 \\
\hline $\begin{array}{l}\text { G-IIId } \\
\text { LED } \\
60 \mathrm{~s} \\
\end{array}$ & 107,1 & 2,3 & 106,2 & 3,3 \\
\hline $\begin{array}{c}\text { G-IIIe } \\
\text { LED } \\
90 \mathrm{~s} \\
\end{array}$ & - - & -- & 110,1 & 4,5 \\
\hline
\end{tabular}


Tabela 3.2

\begin{tabular}{|c|c|c|}
\hline \multicolumn{2}{|c|}{ Tabela dos valores médios MHV no topo } \\
\hline GRUPO & MÉDIA & Desvio Padrão \\
\hline $\begin{array}{c}\text { Lâmpada Halógena -TOPO } \\
(40 \mathrm{~s})\end{array}$ & 124,4 & 4,5 \\
\hline $\begin{array}{c}\text { Laser de } \\
\text { Argônio- TOPO } \\
(10 \mathrm{~s})\end{array}$ & 130,7 & 2,2 \\
\hline $\begin{array}{c}\text { LED - TOPO } \\
(40 \mathrm{~s})\end{array}$ & 121,9 & 3,6 \\
\hline
\end{tabular}

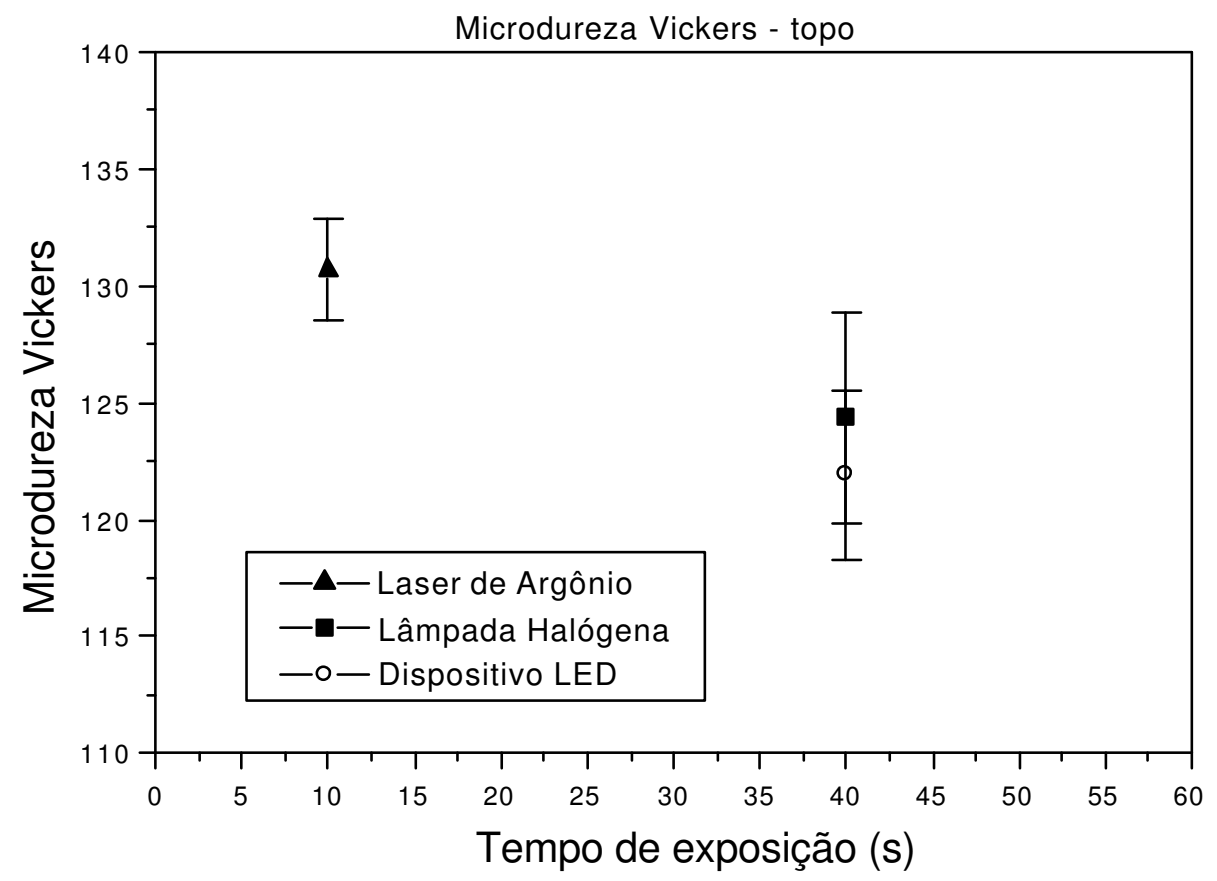

Figura 3.4 Gráfico de microdureza Vickers no topo 
Dispositivos LED para polimerização de resinas compostas dentais: comparação com outras fontes de luz. Capítulo III: Estudo da microdureza em função da espessura e tempo de exposição

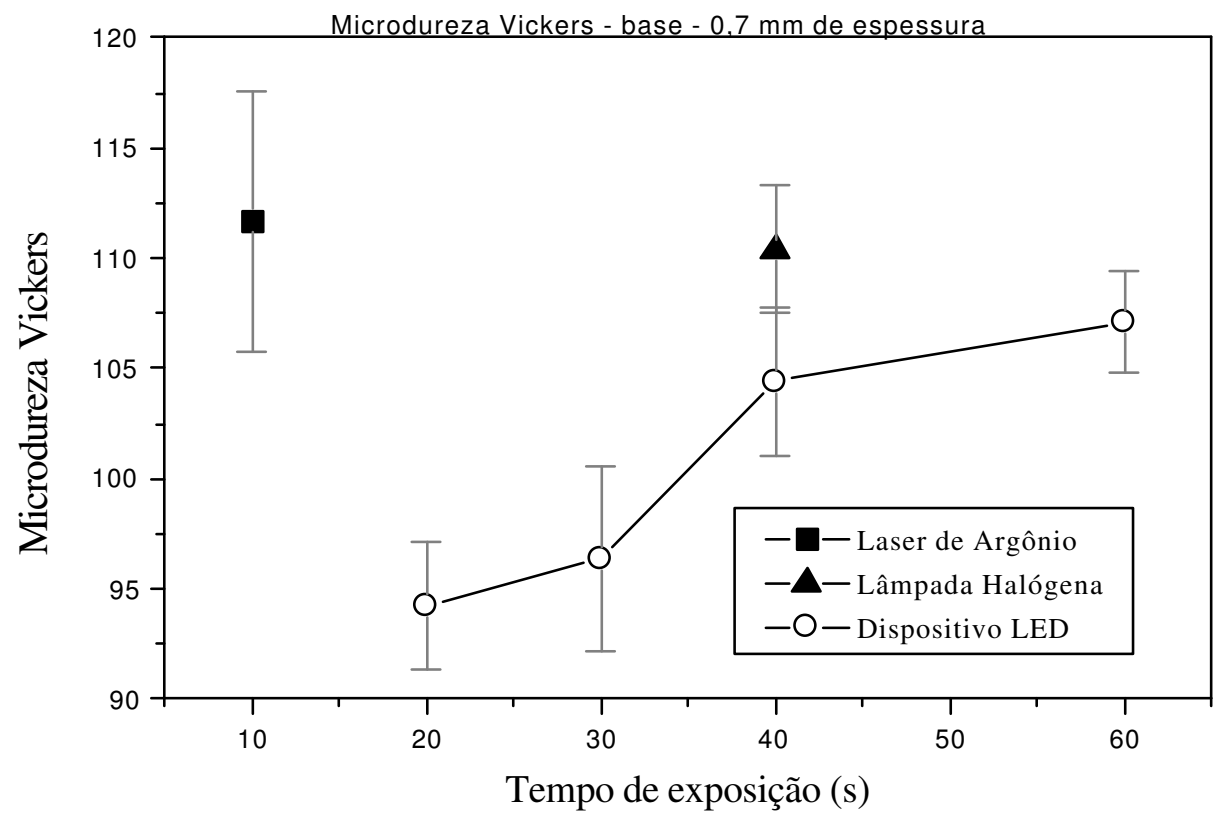

Figura 3.5 - Gráfico de microdureza Vickers na base de espécimes de $0,7 \mathrm{~mm}$ de espessura.

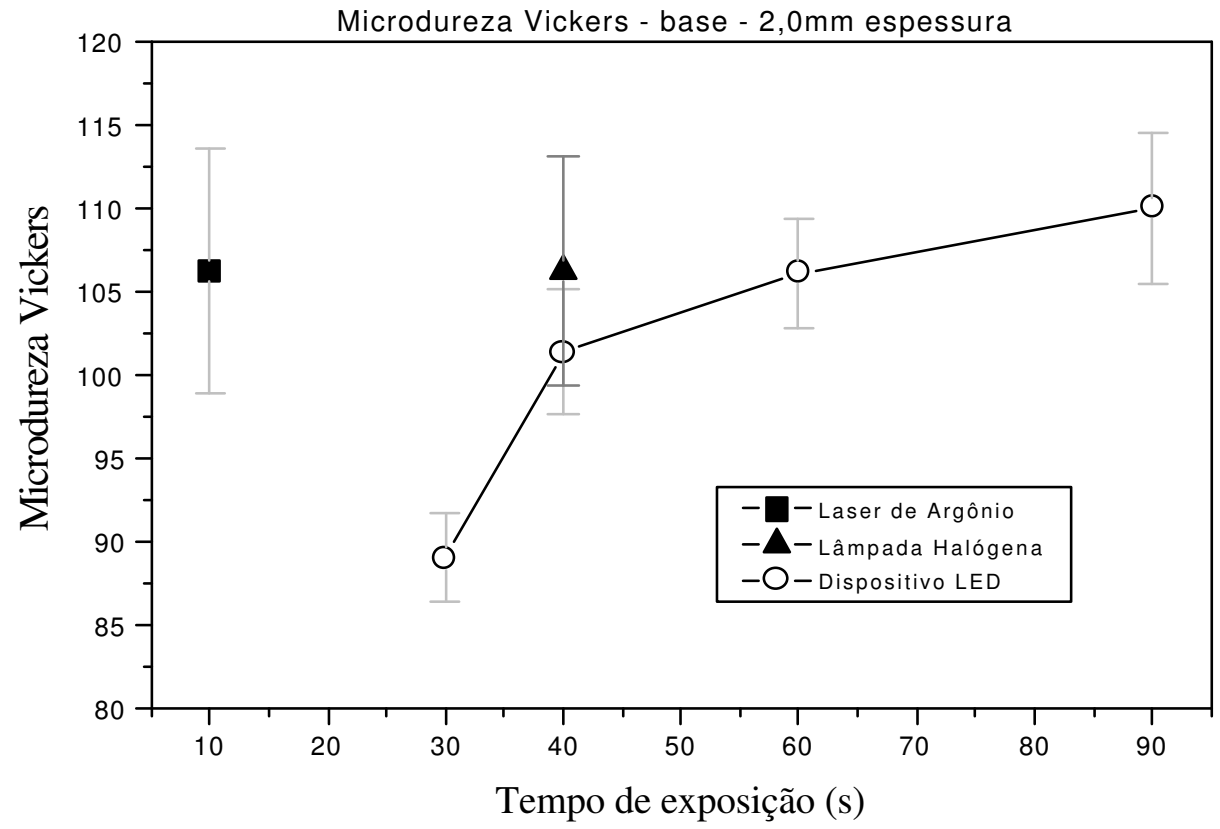

Figura 3.6 - Gráfico de microdureza Vickers na base de espécimes de 2,0 mm de espessura. 


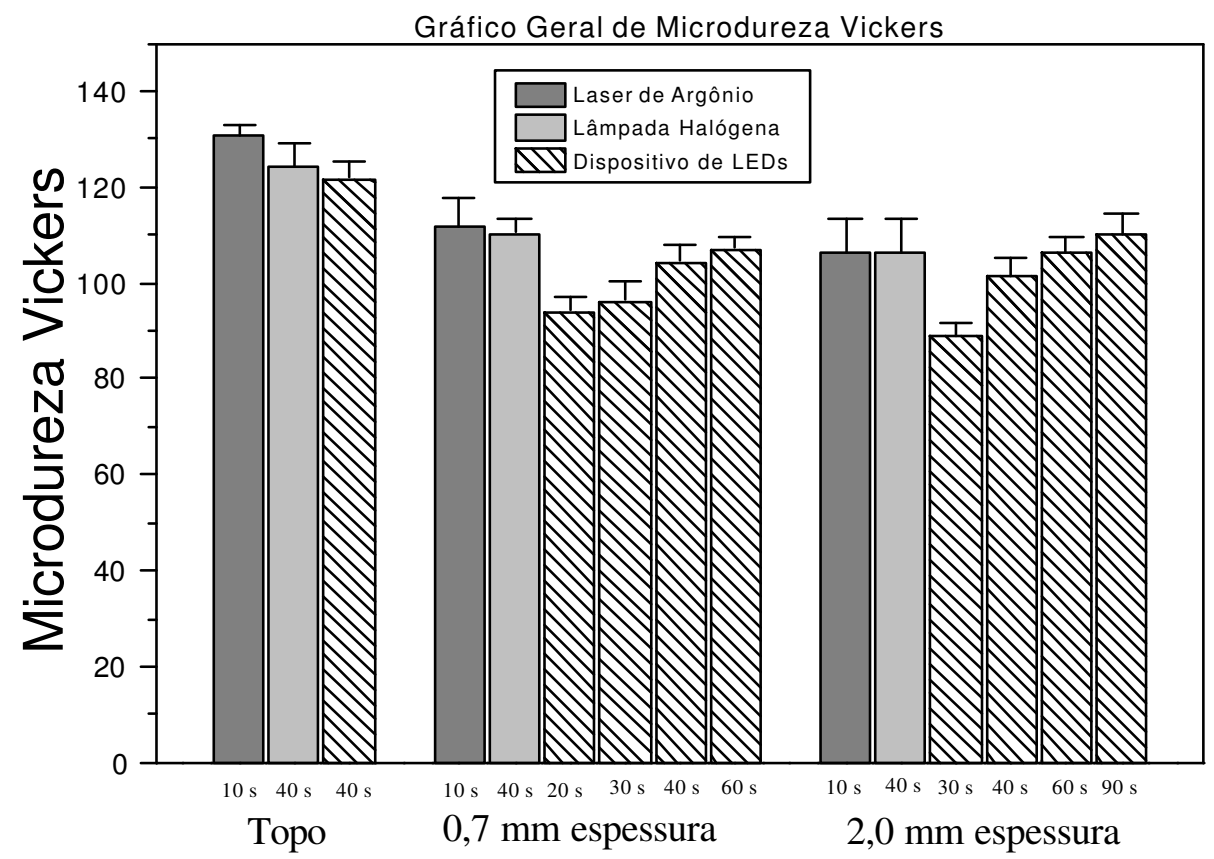

Fig 3.7 - Gráfico geral dos valores de microdureza Vickers

Os valores de microdureza Vickers foram analisados estatisticamente, sendo considerados dados normais, quando aplicado o teste de normalidade (aderência à curva normal). Na análise de Variância, obtivemos os resultados representados na tabela 3.3.

Tabela 3.3

\begin{tabular}{|c|c|c|cc|c|}
\hline \multicolumn{7}{|c|}{ ANÁLISE DE VARIÂNCIA } \\
\hline & $\begin{array}{c}\text { Soma do } \\
\text { Quadrado }\end{array}$ & $\begin{array}{c}\text { Grau de } \\
\text { Liberdade }\end{array}$ & $\begin{array}{c}\text { Quadrado } \\
\text { Médio }\end{array}$ & F. & Prob./(H.B.) \\
\hline Entre colunas & 8898,6 & 14 & 635,6 & 34,23 & $0,00 \%$ \\
\hline Resíduo & 1114,1 & 60 & 18,6 & - & - \\
\hline Variação total & 10012,8 & 74 & - & - & - \\
\hline
\end{tabular}

Quando aplicado o teste de Turkey, ao nível de probabilidade de 5\%, o valor crítico calculado ficou em 9,6. 
Os valores de microdureza Vickers foram verificados, apenas 48 horas após a irradiação, em todos os espécimes deste estudo.

Verifica-se, inicialmente, uma diferença significativa entre os valores de dureza obtidos com as três fontes de luz na superfície diretamente irradiada (topo) em relação à face oposta a irradiação (base) nos espécimes de ambas as espessuras.

Utilizando o laser de argônio, em período de irradiação de apenas 10 segundos, a resina composta atinge valores de microdureza iguais estatisticamente às outras fontes de luz no topo e na base, em ambas as espessuras, demonstrando uma alta eficiência no processo de cura.

Os valores de dureza obtidos na face iluminada diretamente (topo) mostram que as três fontes de luz para polimerização apresentam-se equivalentes nesta superfície, com uma variação no valor de dureza inferior a $10 \%$ e os valores de dureza no topo foram melhores que os valores obtidos a $0,7 \mathrm{~mm}$ e $2,0 \mathrm{~mm}$ de espessura. Com este resultado, demonstramos uma importante aplicabilidade do dispositivo à base de LEDs quando camadas bem finas são empregadas e somente a dureza superficial é importante. Esta aplicação inclui o uso profilático das resinas compostas como selantes para proteção das cicatrículas e fissuras dentais.

Quando se utilizam espécimes de resina composta de $0,7 \mathrm{~mm}$ de espessura, o presente resultado demonstra que tempos de exposição compatíveis com o tempo recomendado pelo fabricante para a lâmpada halógena, é suficiente para que, com o dispositivo à base de LEDs obtenham-se valores de microdureza Vickers equivalentes para incrementos de espessuras iguais ou inferiores a $0,7 \mathrm{~mm}$ na superfície oposta à face iluminada. Na superfície oposta à irradiação em espécimes de $0,7 \mathrm{~mm}$ de espessura, a utilização do dispositivo à base de LEDs em um tempo de 
Dispositivos LED para polimerização de resinas compostas dentais: comparação com outras fontes de luz. Capítulo III: Estudo da microdureza em função da espessura e tempo de exposição

irradiação de 40 segundos, apresentou-se estatisticamente igual aos valores obtidos quando se utilizou o aparelho convencional também por 40 segundos ou o laser de argônio em 10 s de irradiação.

Para os espécimes com espessura de 2,0 mm, um tempo de exposição de 40 segundos foi necessário para obtenção de valores de microdureza equivalentes aos obtidos com a lâmpada halógena em 40 segundos de exposição ou com o laser de argônio. Em virtude de apresentar-se no limite do valor crítico, consideramos um tempo de irradiação de $60 \mathrm{~s}$ mais seguro, para o dispositivo à base de LEDs, em incrementos de 2,0 $\mathrm{mm}$ de espessura.

Estes resultados iniciais indicam que o dispositivo à base de LEDs apresentase como uma fonte de luz viável, com a finalidade de polimerização de resinas compostas dentais fotoativadas, no entanto, com uma relação custo-benefício mais favorável no quesito consumo de energia elétrica e no menor custo do aparelho.

Muitos estudos mostram que a microdureza é um bom indicador para avaliar a polimerização quando se utilizam várias fontes de luz. [38][52]

A profundidade de polimerização é afetada por diversos fatores, incluindo a intensidade do aparelho de polimerização, o tempo de exposição, a distância entre a resina composta e a ponteira do dispositivo, a composição da resina composta (porcentagem de BIS-GMA e TEG-DMA), os tipos de partículas, o tamanho das partículas e outros. [36][40][52]

A obtenção de uma microdureza de superfície adequada não garante uma polimerização completa em todo o corpo do material. Nossos resultados coincidem com outros trabalhos que têm demonstrado que o grau de polimerização decresce com o aumento da distância da superfície exposta à irradiação. [22] 
Dispositivos LED para polimerização de resinas compostas dentais: comparação com outras fontes de luz. Capítulo III: Estudo da microdureza em função da espessura e tempo de exposição

Uma polimerização pobre nas regiões mais profundas de uma restauração de resina composta pode levar a cáries secundárias, formação de fendas, infiltração marginal e irritações pulpares.

Podemos verificar, de acordo com os resultados obtidos, que a microdureza Vickers obtida com o dispositivo à base de LEDs em períodos de exposição superiores a 40 segundos, apresentam valores acima de 100 Vickers, mostrando um adequado desempenho da fonte de luz, mesmo quando espessuras de $2,0 \mathrm{~mm}$ de resinas composta são utilizadas.

Em amostras de 0,7 mm de espessura, o uso do aparelho à base de diodos azuis, com intensidade de apenas $100 \mathrm{~mW} / \mathrm{cm}^{2}$ para polimerização dos espécimes, produziu valores de microdureza Vickers equivalentes aos resultados obtidos quando utilizamos a lâmpada halógena convencional operando com intensidade de 700 $\mathrm{mW} / \mathrm{cm}^{2}$ em tempos iguais de irradiação. Isso é possível por causa da pureza espectral da emissão dos diodos azuis utilizados, onde toda a energia está concentrada na região adequada para promover a fotoiniciação. Por outro lado, nos aparelhos de polimerização convencional, o espectro de emissão do dispositivo carrega muita radiação inadequada para a excitação dos fotoiniciadores, contribuindo somente para o aquecimento.

Em amostras de 2,0 mm de espessura, para a obtenção de valores de microdureza Vickers equivalentes entre a lâmpada halógena em tempo de irradiação de 40 segundos e o dispositivo à base de LEDs, verificou-se a igualdade estatística quando se aumentou o tempo de irradiação do LED para 60 segundos. Apesar do aumento do tempo de exposição quando se utiliza o dispositivo à base de LEDs, o aparelho apresenta um tempo ainda aceitável para sua aplicação clínica. 
A partir dos resultados, determinamos a taxa de redução da microdureza em função da profundidade utilizando equações de taxa, tipo Arrhenius, indicadas da seguinte forma:

$$
M H V=M H V_{0} \cdot \exp (-b x)
$$

Onde, $M H V$ é a microdureza Vickers, $M H V_{o}$ é a microdureza Vickers na superfície diretamente irradiada, $b$ é a taxa de redução da microdureza, e $x$ é a profundidade. Os gráficos obtidos para o aparelho convencional e o dispositivo à base de LEDs estão representados nas figuras 3.8 e 3.9

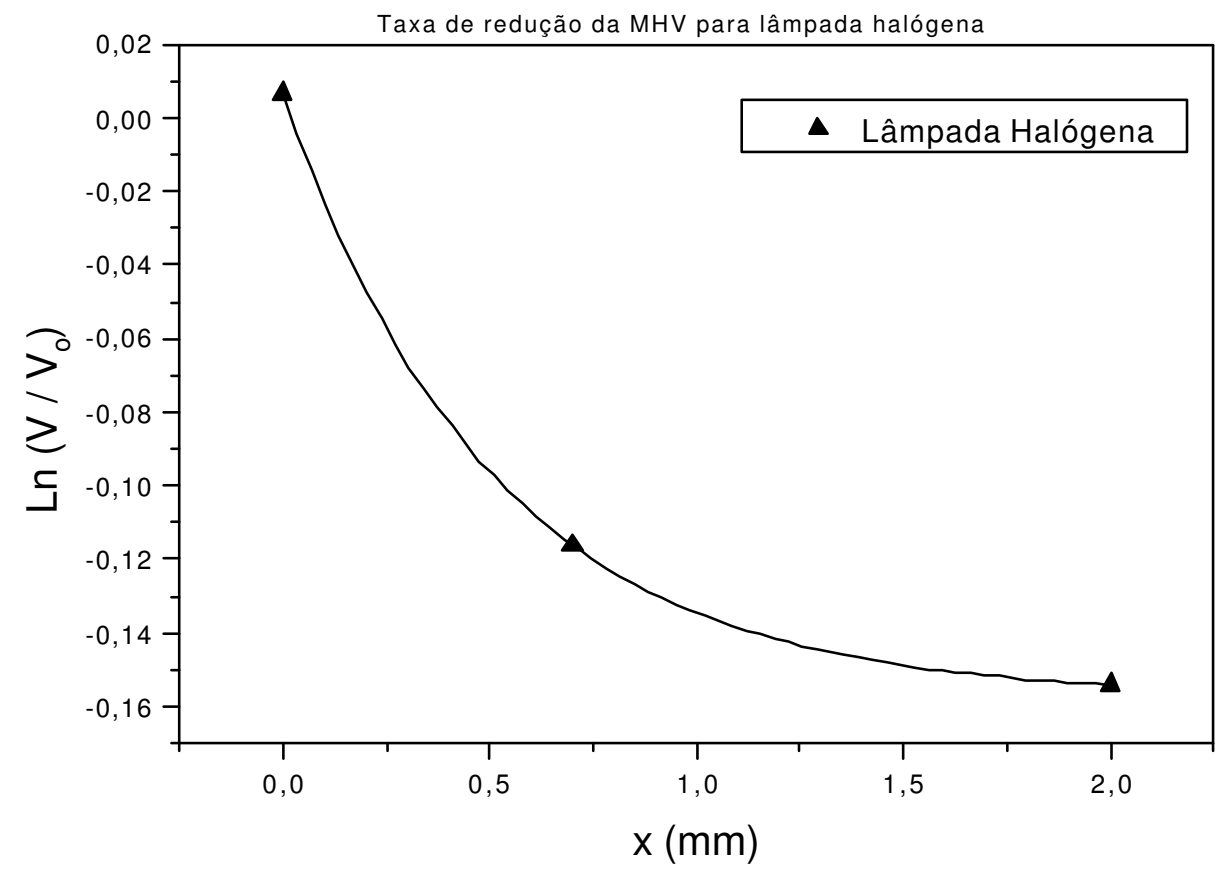

Figura 3.8 - Gráfico mostrando a taxa de redução da microdureza Vickers em função da espessura do espécime quando irradiada pelo aparelho de cura convencional por $40 \mathrm{~s}$. 


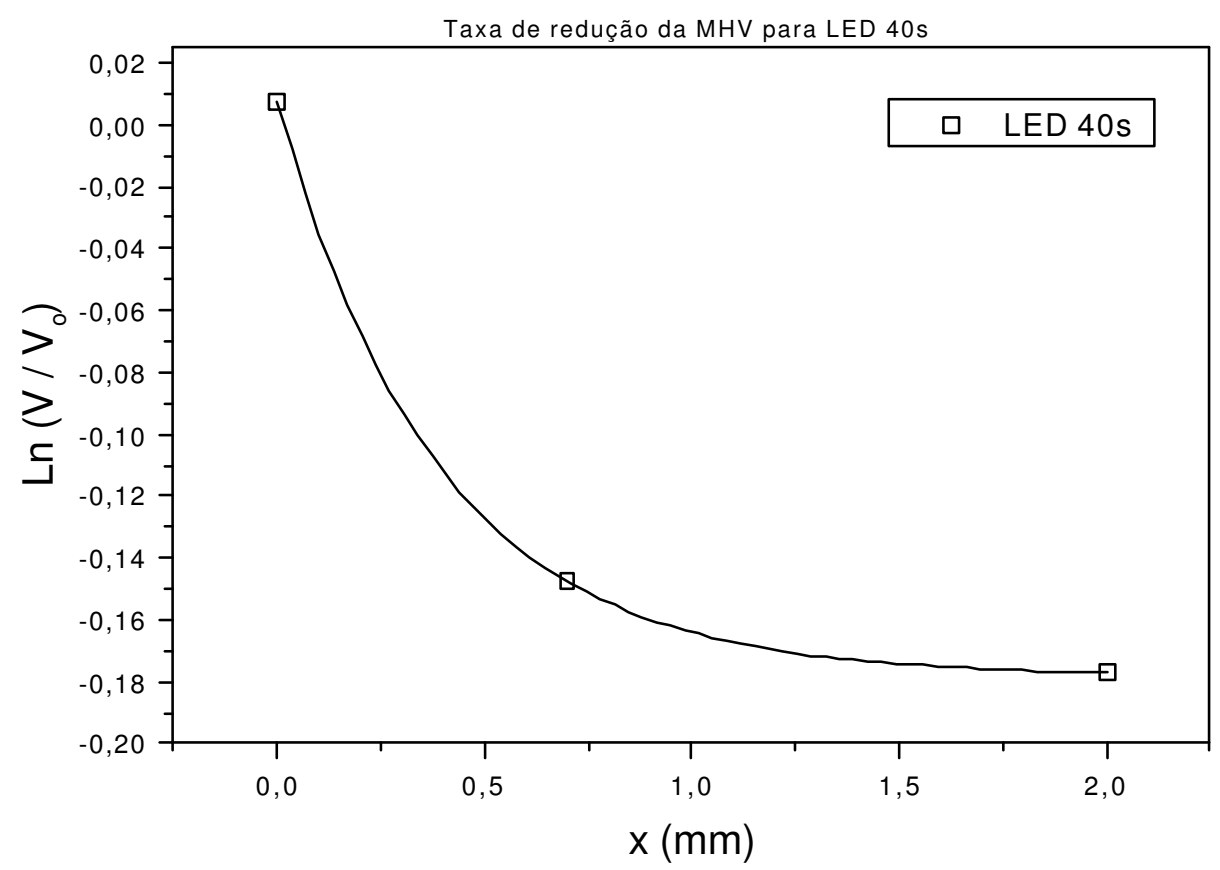

Figura 3.9 - Gráfico mostrando a taxa de redução da microdureza Vickers em função da espessura do espécime quando irradiada pelo dispositivo de cura à base de LEDs por $40 \mathrm{~s}$.

Em seguida, determinamos a taxa de redução da intensidade de luz irradiada para a cura em função da espessura de resina composta, através da análise de imagens, obtidas por uma câmera CCD, de um espécime de resina composta Z-100 A3 (3M do Brasil) irradiada com o dispositivo de cura à base de LEDs e o aparelho convencional. Os resultados da redução de intensidade para as duas fontes de luz foram tratados por equação do tipo Arrhenius mostrados em forma de gráfico na figura 3.10. A equação de taxas é equivalente a equação 2, substituindo o fator número de dureza Vickers ( $M H V)$ pelo fator intensidade $(I)$. 

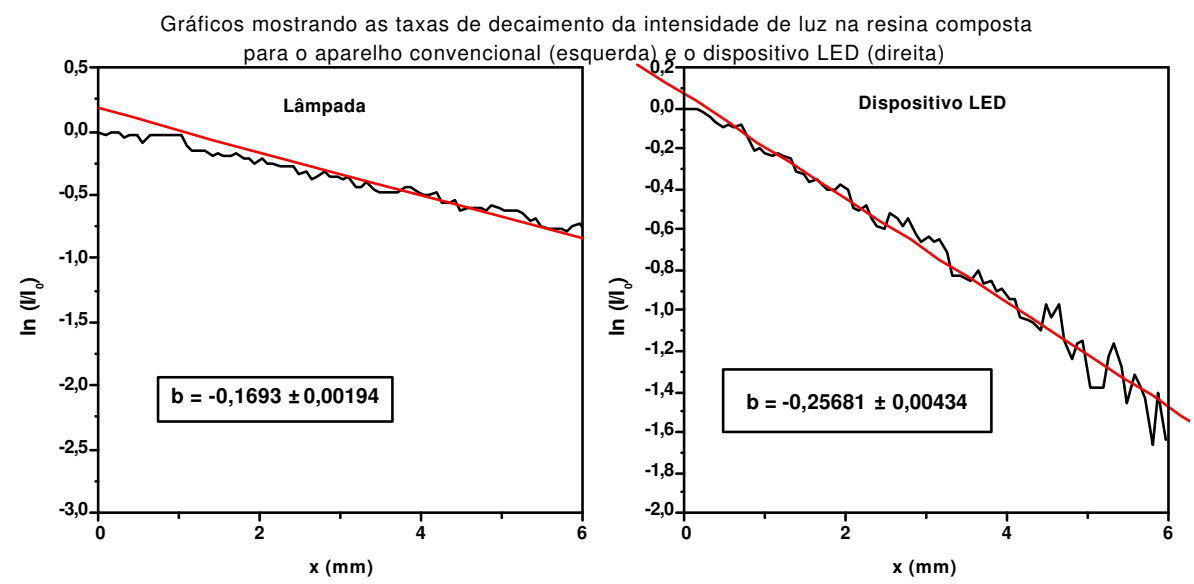

Figura 3.10 - Gráfico mostrando a taxa de redução da intensidade de luz em função da profundidade da resina composta quando irradiada pela lâmpada convencional (à esquerda) e com o dispositivo LED (à direita).

O gráfico 3.10 nos mostra a taxa de redução da intensidade da luz em função da espessura de resina composta para o aparelho convencional e para o dispositivo à base de LEDs. Podemos verificar que o valor de $\boldsymbol{b}$ foi diferente para cada fonte de luz, indicando que o coeficiente angular da reta de ajuste do gráfico tem dependência do espectro de emissão da luz incidente na resina composta, ou seja, a redução da intensidade de luz dentro do material depende do comprimento de onda. Por outro lado, a taxa de redução da intensidade independe da potência da fonte de luz.

Através de uma análise comparativa do gráfico 3.10 com os gráficos 3.8 e 3.9, podemos verificar que não há uma proporcionalidade entre a redução da microdureza Vickers e a intensidade em função da espessura de resina composta. Determinamos, então, que a dureza local não depende somente da intensidade de luz. Maiores profundidades parecem equivaler a uma menor penetração da luz. Estes 
resultados confirmam o fato de que a cura da resina composta, para atingir propriedades adequadas, depende da energia absorvida em cada ponto. Assim:

$$
E=I . \Delta t
$$

Onde $E$ é a energia, $I$ é a intensidade e $\Delta t$ é o tempo de irradiação. Desta forma, o fator tempo passa a assumir um papel preponderante durante o processo de ativação dos fotoiniciadores.

Nossos resultados demonstraram que o dispositivo experimental à base de LEDs é um importante progresso para o desenvolvimento de novos aparelhos para polimerização de materiais odontológicos fotoiniciados. Este experimento demonstrou que o dispositivo à base de LEDs azuis pode polimerizar resinas compostas dentais em diferentes espessuras, obtendo valores de microdureza compatíveis aos valores obtidos nos espécimes polimerizados com o aparelho convencional e com o laser de argônio. Outra importante conclusão é que a dureza não é diretamente proporcional a intensidade de luz, o fator tempo é preponderante para que a dinâmica de fotoativação seja otimizada permitindo à resina composta propriedades mecânicas adequadas. 


\title{
Disposit ivos LED para polimerização de
}

\section{resinas compostas dent ais: comparação}

\author{
com outras f ont es de luz.
}

Capítulo IV: Análise térmica com resolução temporal durante a irradiação pelas

fontes de luz 


\section{INTRODUÇÃO}

A polimerização eficiente das resinas compostas é um fator primordial para o sucesso na utilização desta classe de material e na obtenção de propriedades adequadas para a aplicação clínica. A modificação da temperatura nos tecidos durante a fotopolimerização é um, dentre os vários fatores, a ser considerado no processo de cura.

$\mathrm{O}$ processo de polimerização das resinas compostas atuais inicia-se com a ativação dos fotoiniciadores. O principal iniciador das resinas compostas comerciais é a canforquinona, que se encontra presente na matriz orgânica. A excitação deste fotoiniciador ocorre através de luz visível entre os comprimentos de onda de 450 a 500 nanômetros, com o pico de absorção em 468 nanômetros. [36]

Para a ativação deste processo, existem no mercado diversas fontes de luz, entre elas: o aparelho fotopolimerizador convencional que consiste numa lâmpada halógena com um filtro, o laser de argônio (principalmente na linha de 488 nanômetros), aparelhos que utilizam lâmpada de xenônio e recentemente alguns dispositivos à base de LEDs azuis.

É importante que estes aparelhos, além de promoverem uma polimerização adequada do material, obtendo bom desempenho das propriedades físicas e mecânicas, não gerem danos térmicos aos tecidos orais.

Estudos prévios demonstraram que o laser de argônio e o dispositivo à base de LEDs azuis são unidades alternativas para a polimerização das resinas compostas dentais, obtendo propriedades de microdureza comparáveis ao dispositivo de polimerização convencional. [29] 
Dispositivos LED para polimerização de resinas compostas dentais: comparação com outras fontes de luz. Capítulo IV - Análise térmica com resolução temporal durante a irradiação pelas fontes de luz

KURACHI e colaboradores usaram arranjos de LEDs azuis (Nichia ltd., Anan, Japan) utilizando 2, 3, 4, 5 e 6 LEDs em cada ponteira de diâmetro interno de $6 \mathrm{~mm}$. Verificaram a microdureza Vickers de resinas compostas Z-100, cor A3, polimerizadas com estes dispositivos experimentais em tempos de exposição de 20, 40, 60, 120 e 180 segundos e compararam com os valores de microdureza obtidos com o dispositivo convencional de lâmpada halógena em tempos de exposição de 40 segundos. Os espécimes foram preparados em espessuras de $0.35,1.25$ e $1.8 \mathrm{~mm}$. Os resultados demonstraram que os espécimes polimerizados com dispositivos experimentais à base de 2,3,4 e 5 LEDs azuis apresentaram valores de microdureza inferior à lâmpada halógena, mas quando utilizado o arranjo de 6 LEDs em camadas mais finas de resina composta ou em tempos de exposição maiores a microdureza atingiu valores considerados adequados. [29]

No capítulo anterior, obtivemos valores de microdureza Vickers similares em espécimes de 0,7 mm de espessura, utilizando: a lâmpada halógena convencional (350 miliwatts em tempo de exposição de 40 segundos), o laser de argônio (linha 488 nm, 500 miliwatts em tempo de exposição de 10 segundos) e utilizando o novo dispositivo experimental à base de LEDs azuis (50 miliwatts, em tempo de exposição de 40 segundos). Quando utilizaram espécimes de 2,0 $\mathrm{mm}$ de espessura valores de microdureza similares foram obtidos entre o dispositivo convencional em tempo de exposição de 40 segundos e o dispositivo experimental à base de LEDs em período de exposição de 60 segundos.

Apesar de o laser de argônio apresentar polimerização de resinas compostas em períodos de exposição curtos (em torno de 10 segundos), obtendo propriedades mecânicas bastante favoráveis e dos dispositivos convencionais apresentarem bons 
resultados em sua utilização clínica, um dos problemas relatado pelos autores é a variação de temperatura nos tecidos orais e dentais sob irradiação, especialmente os efeitos pulpares quando diferentes fontes de luz para polimerização de compósitos são utilizados. [1][7][12][27][39]

BRENNEISE e BLANKENAU estudaram os efeitos do laser de argônio nos tecidos moles orais quando expostos ao laser de argônio durante a polimerização de compósitos. Os resultados histológicos demonstraram que a utilização do laser de argônio, em períodos de exposição relevantes clinicamente (10 segundos), operando com 231 miliwatts e diâmetro de feixe de $5 \mathrm{~mm}$, nos tecidos gengivais paraqueratinizados adjacentes ao dente a ser restaurado, não apresentaram danos significantes. [7]

Um estudo clássico que verifica o efeito da aplicação de calor nos tecidos pulpares foi executado por ZACH E COHEN. Estes autores estudaram os efeitos da transferência de calor para os tecidos pulpares em macacos da espécie Macaca rhesus, utilizando evidências histológicas de inflamação. Os resultados verificaram que para uma variação na temperatura pulpar de $2,2^{\circ} \mathrm{C}$ praticamente não ocorria reação, para variação de temperatura pulpar de $5,5^{\circ} \mathrm{C}$ cerca de $15 \%$ dos dentes aquecidos apresentaram necrose e para uma variação de cerca de $11^{\circ} \mathrm{C}$ um total de $60 \%$ dos dentes estudados necrosaram. [53]

Baseados nos estudos de Zach e Cohen, KURACHI e colaboradores determinaram os parâmetros de segurança para o uso do laser de argônio para polimerização de resinas compostas. Eles observaram que o dispositivo convencional que utiliza lâmpada halógena induz a uma variação de temperatura similar à variação de temperatura causada pelo laser de argônio (linha 488 nm) operando com 300 
miliwatts de potência no grupo dos molares. Verificaram também que, quando a potência do laser de argônio foi aumentada para 500 miliwatts foram necessários 32 segundos para alcançar a variação de temperatura de $5^{\circ} \mathrm{C}$, considerada uma temperatura crítica. [27]

Neste capítulo, estabelecemos um estudo comparativo verificando a variação de temperatura intrapulpar de terceiros molares recém-extraídos, com resolução temporal durante o processo de exposição a três diferentes fontes de luz: lâmpada halógena com filtro, laser de argônio e dispositivo experimental à base de LEDs azuis. O principal objetivo deste estudo é conhecer o nível de dano térmico que cada fonte pode promover, bem como determinar como ocorre o resfriamento dos dentes após o aquecimento com cada fonte de luz. 


\section{MATERIAIS E MÉTODOS}

\section{Preparação dos dentes}

Para a realização deste experimento, foram utilizados 08 (oito) dentes, 3 os molares humanos impactados ou inclusos recém-extraídos, mantidos por dois dias em solução de glutaraldeído, em seguida, armazenados em água destilada para manter a hidratação até a realização do experimento. Confeccionou-se cavidades tipo Classe V nas faces vestibulares dos dentes, incluindo no preparo a porção da junção amelo-cementária. As cavidades foram preparadas em dimensões de $2 \mathrm{~mm}$ na direção corono apical, $2 \mathrm{~mm}$ na direção mésio-distal e $2 \mathrm{~mm}$ de profundidade, utilizando-se, para isso, a máquina de confecção de cavidades padronizadas da Faculdade de Odontologia de Araraquara - UNESP equipada com ponta carbide 245 (carbide burn, JET, Canadá), em caneta de alta rotação (Dabi Atlante), com refrigeração de ar e água durante o preparo.

Através da confecção de cavidade na face lingual dos dentes, com a utilização de caneta de alta rotação com refrigeração de ar e água equipada com ponta carbide 245 (carbide burn, JET, Canadá), pôde-se acessar a câmara pulpar.

A câmara pulpar foi limpa com solução de hipoclorito de sódio e solução fisiológica e utilizado sugador de alta potência para remoção dos tecidos necróticos. Após a sucção da cavidade pulpar, preenchemos todo o seu conteúdo com pasta térmica condutora, evitando a presença de bolhas de ar para permitir uma boa transferência de calor. Termistores de alta precisão (Model 120-202EAJ, Fenwal Electronic, MA, USA) foram adaptados tocando a parede pulpar mais próxima à 
parede axial do preparo cavitário classe V. Os termistores foram fixados nesta posição, com a utilização resina composta (Z100, 3M, Brasil) restaurando a cavidade de acesso à câmara pulpar pela face lingual dos dentes. A resina composta para fixação do termistor foi polimerizada pelo fotoativador convencional à base de lâmpada halógena com filtro (200 R, K\&M, São Carlos, Brasil), previamente a realização das medidas. $\mathrm{O}$ ápice radicular foi também fechado utilizando resina composta. Detalhes observados nas figuras 4.1 e 4.2

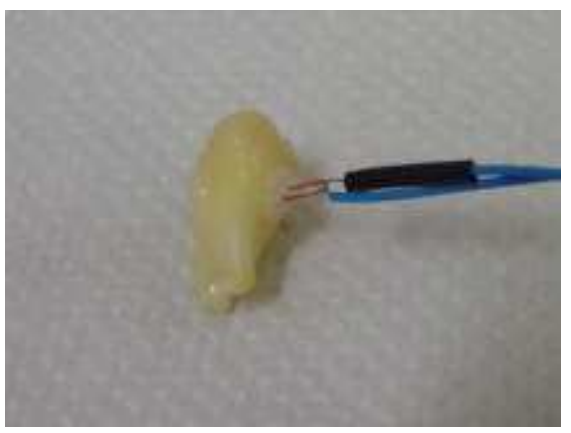

Figura 4.1 - Termistor adaptado no interior da câmara pulpar

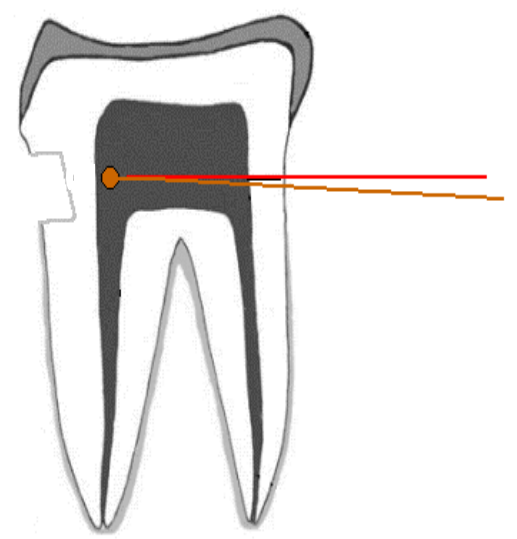

Figura 4.2 - Figura esquemática para demonstrar o posicionamento do termistor no interior da câmara e da cavidade Classe V. 


\section{Aparato Experimental}

Para simulação do ambiente oral, elaboramos um dispositivo composto por um recipiente de vidro com abertura lateral, semipreenchido com água mantida a $36,5^{\circ} \mathrm{C}\left( \pm 0,5^{\circ} \mathrm{C}\right)$ através de uma resistência. Dentro do recipiente, temos uma haste vertical de acrílico para fixação do dente. O dente foi fixado na haste vertical com auxílio de cera utilidade e fios metálicos mantendo a porção radicular imersa na água até próximo à junção amelo-cementária. $\mathrm{O}$ dispositivo está representado esquematicamente na figura 4.3

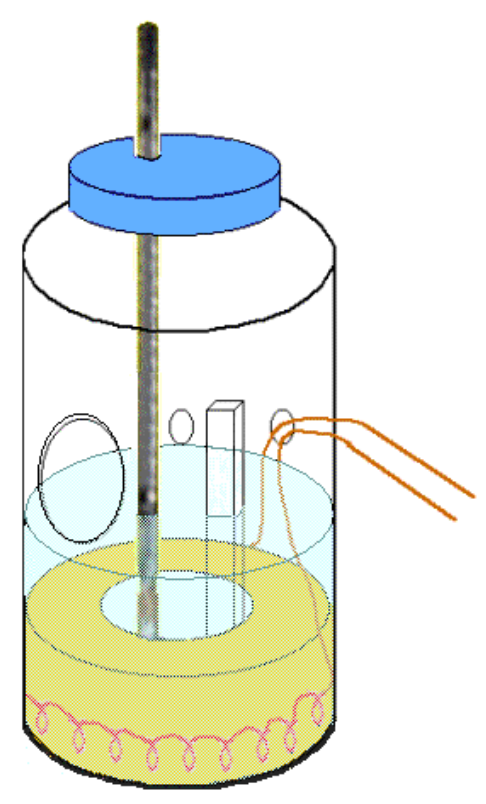

Figura 4.3 - Desenho esquemático do aparato experimental para simular as condições térmicas da cavidade oral. 
O termistor de alta precisão utilizado (Model 120-202EAJ, Fenwal Electronic, MA, USA) indica a variação de tensão quando há modificação de temperatura. O termistor foi conectado a uma placa de aquisição de dados no microcomputador para armazenamento dos dados de tensão.

\section{$\underline{\text { Exposição à luz }}$}

Neste experimento, estamos interessados no total de calor transferido para os dentes, por isso, executamos a irradiação sem o preenchimento da cavidade com resina composta. Em experimento prévio, realizado por KURACHI e colaboradores, verificou-se que a variação de temperatura pratic amente não sofria alterações com ou sem o preenchimento da cavidade com resina composta.

As fontes de luz e suas condições operacionais, para simular a utilização em uso clínico, foram divididas nos seguintes grupos:

- G I: Laser de Argônio (INNOVA 100, coherent, USA), potência de 300 mW e tempo de exposição de 10 segundos;

- G II: Laser de Argônio (INNOVA 100, coherent, USA): potência de 500 mW e tempo de exposição de 10 segundos;

- G III: Fotopolimerizador convencional (200 R, K\&M, Brasil), potência de 350 mW e tempo de exposição de 20 segundos; 
- G IV: Fotopolimerizador convencional ( $200 \mathrm{R}, \mathrm{K} \& \mathrm{M}$, Brasil), potência de 350 mW e tempo de exposição de 40 segundos;

- G V: Fotopolimerizador convencional ( $200 \mathrm{R}, \mathrm{K} \& \mathrm{M}$, Brasil), potência de 350 mW e tempo de exposição de 60 segundos;

- G VI: Dispositivo à base de LEDs desenvolvido no IFSC-USP, potência de 50 mW e tempo de exposição de 60 segundos;

Os aparelhos para polimerização foram utilizados com o diâmetro de saída do feixe de $8 \mathrm{~mm}$ de diâmetro e o dispositivo de entrega de luz de cada fonte foi fixado a $1 \mathrm{~mm}$ da cavidade para a padronização da distância fonte de luz - cavidade. A variação de tensão foi armazenada pelo microcomputador a cada segundo e foi observado o padrão de aquecimento e o padrão de resfriamento para cada fonte de luz. A figura 4.4 mostra esquematicamente a irradiação do dente pela fonte de luz.

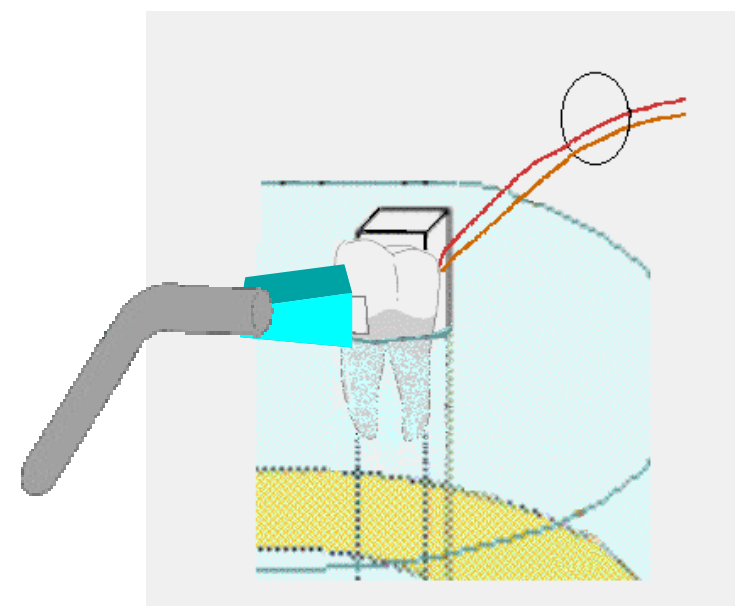

Figura 4.4 - Representação esquemática da irradiação com as fontes de luz. 
As fontes de luz, em seus respectivos tempos de exposição, foram utilizadas por três ciclos em cada dente. No final do experimento, os termistores foram calibrados e os valores de tensão convertidos em valores de temperatura.

Com as variações térmicas observadas em todos os grupos, procedemos a uma análise, dando atenção a diferentes aspectos. Nesta parte do experimento, são relatados os efeitos da variação térmica na polpa, quando exposta a diferentes fontes de luz para polimerização.

Foram utilizados também outros dentes com cavidades Classe $\mathrm{V}$ na face vestibular e adaptados termistores de alta precisão (Model 120-202EAJ, Fenwal Electronic, MA, USA) dentro da restauração de resina composta que preenchia esta cavidade. A restauração com o termistor adaptado foi irradiada com: a-) laser de argônio (INNOVA 100, coherent, USA), $500 \quad \mathrm{~mW}, \quad 10 \quad$ segundos; $\quad$ b-) fotopolimerizador convencional (200 R, K\&M, Brasil), $350 \mathrm{~mW}, 40$ segundos; c-) Dispositivo experimental à base de LEDs, $50 \mathrm{~mW}, 60$ segundos. 


\section{RESULTADOS E DISCUSSÕES}

Nesse experimento, podemos observar os perfis de aquecimento e resfriamento obtidos com cada fonte de luz, operando nos parâmetros especificados anteriormente. Como primeira observação, verificamos grande variação de temperatura de um dente para outro, devido à grande variação anatômica deste grupo dental.

As médias de temperatura obtidas nos oito dentes estão resumidas na tabela

\section{1:}

Tabela 4.1:

\begin{tabular}{|c|c|c|cc|c|}
\hline \multicolumn{7}{|c|}{ MÉDIAS DE TEMPERATURA } \\
\hline Grupos & $\begin{array}{c}\text { Média de } \\
\text { pico }\left({ }^{\circ} \mathrm{C}\right)\end{array}$ & $\begin{array}{c}\text { Desvio } \\
\text { Padrão }\end{array}$ & $\Delta \mathrm{T}\left({ }^{\circ} \mathrm{C}\right)$ & $\begin{array}{c}\text { Energia total } \\
\text { fornecida } \\
(\mathrm{J})\end{array}$ & $\begin{array}{c}\mathbf{M}_{\text {theff }} \\
(\mathrm{g})\end{array}$ \\
\hline G I & 38,3 & 0,7 & 1,6 & 3 & 1,6 \\
\hline G II & 39,4 & 1,3 & 2,7 & 5 & 1,6 \\
\hline G III & 37,8 & 0,4 & 1,1 & 7 & 5,4 \\
\hline G IV & 38,9 & 0,8 & 2,2 & 14 & 5,4 \\
\hline G V & 39,6 & 1,0 & 2.9 & 21 & 6,2 \\
\hline G VI & 36,9 & 0,08 & 0.2 & 3 & 12,8
\end{tabular}

Os valores de variação média de temperatura, e os respectivos desvios padrões, estão expostos na forma de gráfico na figura 4.5. 


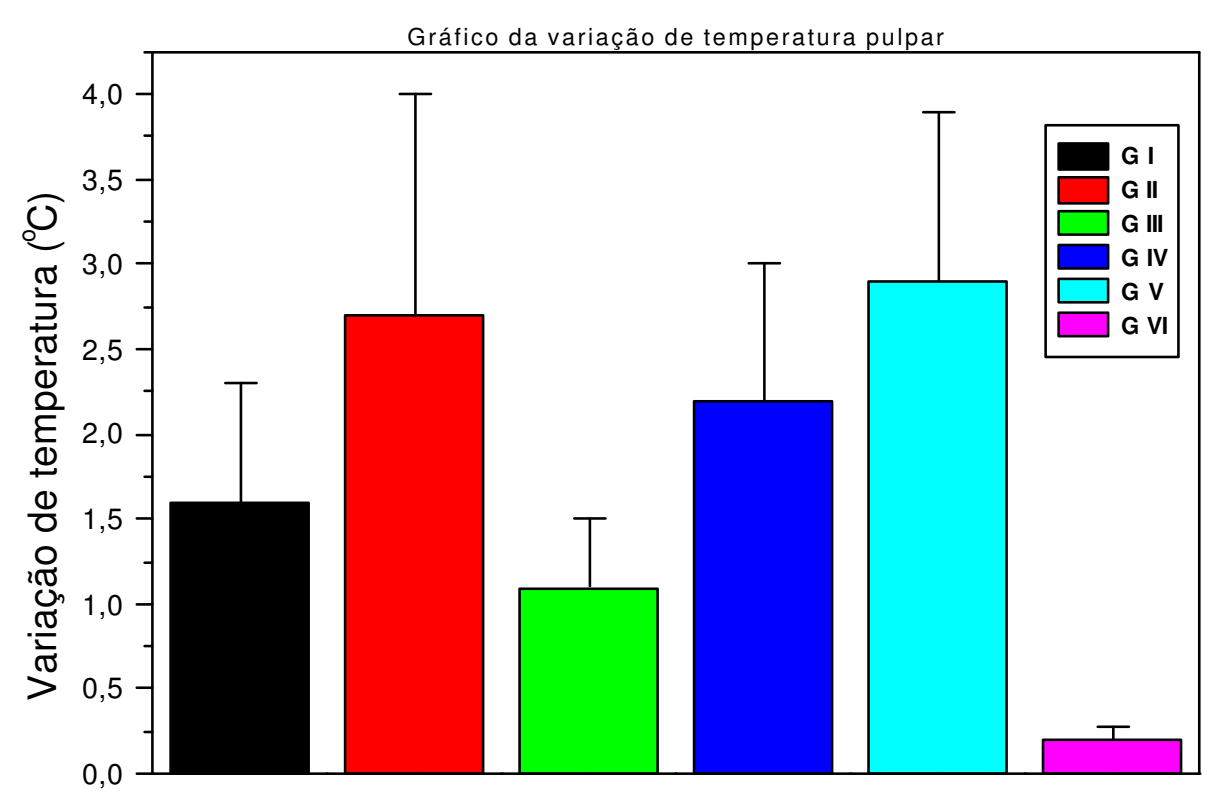

Figura 4.5 - Representação gráfica da variação térmica intrapulpar

Calculamos também a energia total fornecida para os dentes em cada grupo utilizando a equação:

$$
\mathbf{E}=\mathbf{P} \cdot \Delta \mathbf{t}
$$

Onde, $P$ é a potência do dispositivo, $t$ é o tempo de exposição à luz e $E$ é o total de energia dada ao dente (coluna de energia total fornecida da tabela IV).

Utilizando estes dados podemos calcular a massa térmica efetivamente afetada pelo calor ( $\left.\mathrm{M}_{\text {th-eff }}\right)$ com a equação:

$$
\Delta E=m \cdot c \cdot \Delta T
$$


Dispositivos LED para polimerização de resinas compostas dentais: comparação com outras fontes de luz. Capítulo IV - Análise térmica com resolução temporal durante a irradiação pelas fontes de luz

Onde, $E$ é o total de energia dada ao dente, $c$ é o calor específico da dentina, $\Delta T$ é a variação de temperatura e $m$ é a massa efetivamente afetada. $\mathrm{O}$ valor do calor específico da dentina é 0,28 cal. $\mathrm{g}^{-1} \cdot \mathrm{C}^{1}$ ou $1,1715 \mathrm{~J} \cdot \mathrm{g}^{-1} \cdot \mathrm{C}^{1}$ segundo a literatura. [43]

A massa efetivamente afetada ( $\left.\mathrm{M}_{\text {th-eff }}\right)$ é um número que representa a inércia térmica dos dentes quando expostos à radiação de uma determinada fonte de luz, operando em condições específicas. Altos valores de $\mathrm{M}$ theff significam maiores dificuldades para que haja variação de temperatura no substrato. Esses resultados demonstram, em uma análise térmica, a inércia térmica que os dentes apresentam quando cada dispositivo é utilizado. Verificamos uma menor variação de temperatura quando o dispositivo experimental à base de LEDs azuis foi utilizado e isto representa uma maior massa térmica inercial.

Os resultados obtidos demonstraram baixas variações de temperatura para todos os grupos, isso ocorre porque as cavidades Classe $\mathrm{V}$ preparadas nos terceiros molares eram muito rasas, com uma profundidade de $2 \mathrm{~mm}$. Os altos valores de desvio padrão obtidos neste estudo podem estar associados às diferenças anatômicas inerentes ao grupo de dentes de terceiros molares. Os terceiros molares apresentam grandes variações morfológicas e dimensionais tanto na superfície externa quanto na câmara pulpar e devido a isso a espessura da parede de dentina remanescente e a massa total levaram a uma grande diferença nas variações de temperatura de um dente para outro.

Utilizamos o gráfico de um dos dentes, apresentado na figura 4.6, para exemplificar os padrões de aquecimento e resfriamento típicos para cada fonte de luz. Podemos verificar que o padrão de resfriamento apresenta um perfil muito 
semelhante para os diversos grupos em estudo. Este fato se deve ao fato de o processo somente depender das características de dissipação térmica inerentes ao substrato, independentemente da fonte de calor utilizada.

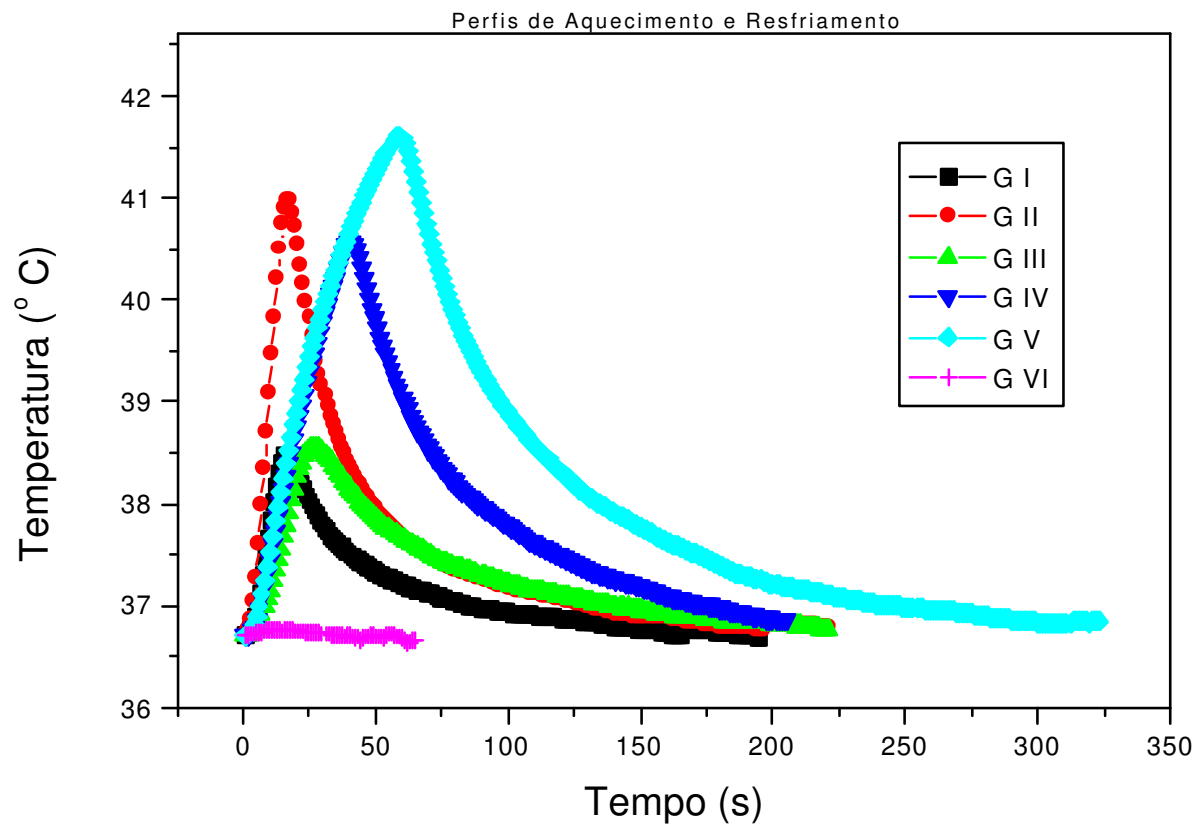

Figura 4.6 - Gráfico de um dos dentes estudados, apresentando o perfil de aquecimento e resfriamento obtido em cada grupo.

Verificamos que a utilização do laser de argônio nas potências de $300 \mathrm{~mW}$ e $500 \mathrm{~mW}$ apresentam grandes variações de temperatura apesar de o tempo de exposição curto. Isso está relacionado ao fato de o laser ser uma fonte de luz colimada apresentando uma grande concentração de energia em um mesmo comprimento de onda.

Calculamos também as taxas médias de aquecimento obtidas nos grupos e através da montagem de um gráfico com os perfis de resfriamento em função logarítmica do tempo podemos verificar melhor a semelhança dos perfis de resfriamento e a taxa média de resfriamento dos terceiros molares estudados. Estes 
detalhes são mostrados na figura 4.7 , através de gráfico. O grupo 6 , referente ao dispositivo à base de LEDs, foi excluído do gráfico por não apresentar um aquecimento suficiente para gerar um padrão de resfriamento que pudesse ser comparado aos demais grupos.

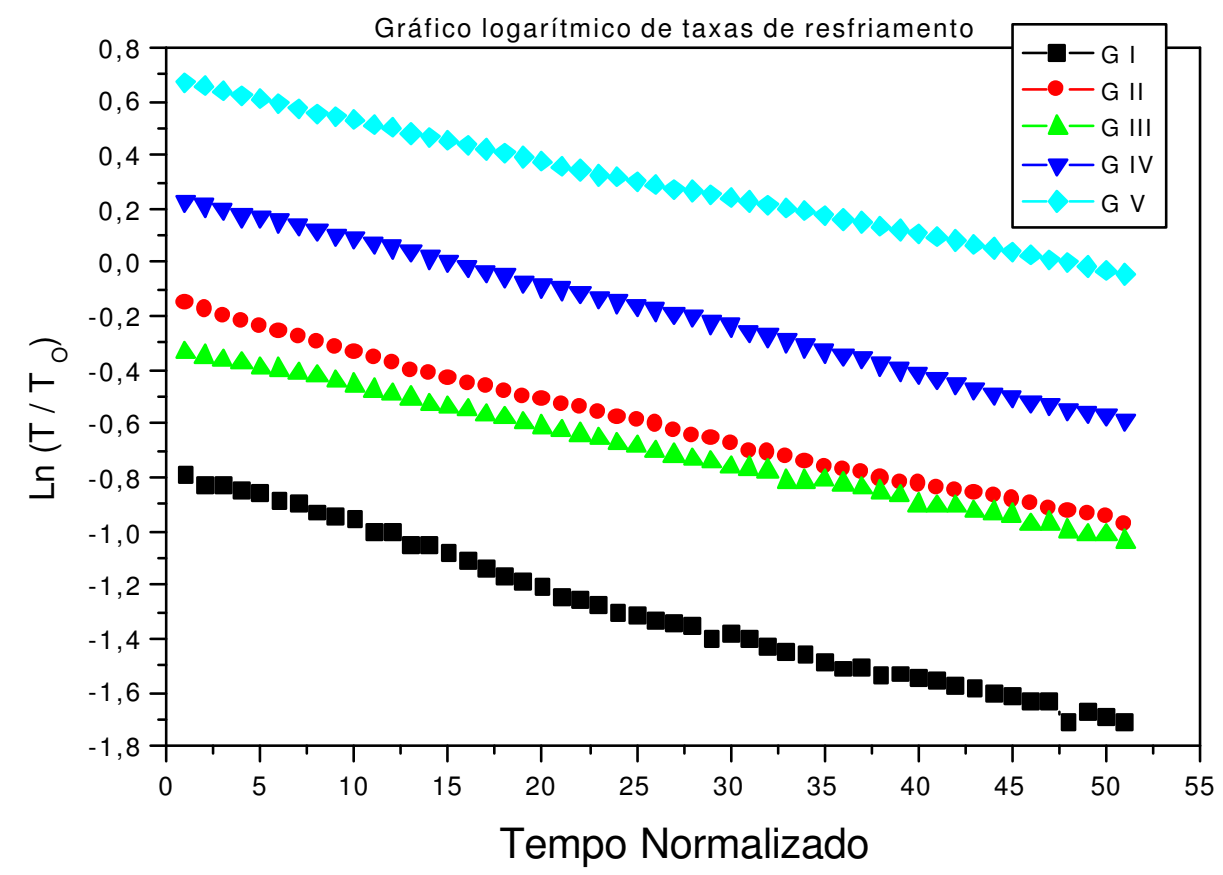

Figura 4.7- Gráfico em escala logarítmica que determina os perfis de resfriamento.

A curva de resfriamento foi ajustada por uma exponencial somente supondo o fenômeno de dissipação por um só processo e foi adotada como um decaimento do tipo Arrhenius, onde a temperatura varia exponencialmente com o tempo:

$$
\mathbf{T}=\mathbf{T}_{\mathbf{o}} \cdot \exp (-\mathbf{b . t})
$$


Onde, $T$ é a temperatura final, $T_{o}$ é a temperatura de pico obtida, $b$ é a taxa de resfriamento e $t$ é o tempo referente à temperatura final $T$. Utilizando o gráfico logarítmico simplificamos a fórmula para:

$$
\operatorname{Ln}\left(\mathbf{T}-\mathbf{T}_{\mathbf{0}}\right)=-\mathbf{b . t}
$$

Através dos cálculos verificamos que o valor de $b$ é de aproximadamente $0,016 \mathrm{~s}^{-1}$, e para estimar o tempo necessário para dissipar aproximadamente $63 \%$ do temperatura de pico calculamos o inverso de $b$, que neste caso é de 60 segundos.

Se fizermos uma comparação das taxas médias de aquecimento em cada grupo e a taxa de dissipação de calor fornecida pelo dente (tabela 4.2), verificamos que a única fonte que gera taxas de calor inferior à taxa que o elemento dental é capaz de dissipar é o dispositivo experimental à base de LEDs, justificando a desprezível variação de temperatura fornecida por este dispositivo mesmo em tempos de exposição de 60 segundos. Para o restante das fontes de luz, operando nos parâmetros determinados para garantir à resina composta propriedades mecânicas adequadas, a taxa de calor fornecida é superior à taxa em que o dente é capaz de dissipar. 
Tabela 4.2

\begin{tabular}{|c|c|c|}
\hline \multicolumn{2}{|c|}{ TAXAS DE AQUECIMENTO E RESFRIAMENTO } \\
\hline Grupos & $\begin{array}{c}\text { Taxa de Aquecimento } \\
\text { Médio } \\
\Delta \mathrm{T} / \Delta \mathrm{t}\left({ }^{\circ} \mathrm{C} / \mathrm{s}\right)\end{array}$ & $\begin{array}{c}\text { Taxa de Resfriamento } \\
\Delta \mathrm{T} / \Delta \mathrm{t}\left({ }^{\circ} \mathrm{C} / \mathrm{s}\right)\end{array}$ \\
\hline G I & 0,16 & \multirow{2}{*}{0} \\
\hline G II & 0,27 & \multirow{2}{*}{0,016} \\
\hline G III & 0,055 & \\
\hline G IV & 0,055 & \\
\hline G V & 0,048 & \\
\hline G VI & 0,003 & \\
\hline
\end{tabular}

A partir destes resultados, podemos explorar que nas condições clínica quando o profissional confecciona a restauração de uma cavidade rasa, o tempo necessário entre a polimerização de um incremento e outro para uma recuperação térmica do dente é de no mínimo 60 segundos. Este tempo ficará ainda maior se a espessura da parede de dentina entre a restauração e a câmara pulpar for mais delgada que as condições experimentais, ou seja, a cavidade clinicamente mais profunda ou o dente a ser restaurado tenha uma menor massa para dissipação de calor (e.g. incisivos e pré-molares).

Na figura 4.8, mostramos, através de um gráfico temperatura vs. tempo de exposição, a variação de temperatura na base de uma restauração de resina composta de 2,0 mm de profundidade quando as três fontes de luz são utilizadas, operando nos seguintes parâmetros clínicos: a-) laser de argônio (INNOVA 100, coherent, USA), potência de $500 \mathrm{~mW}$, em um período de exposição de 10 segundos; b-) fotopolimerizador convencional (200 R, K\&M, Brasil), potência de $350 \mathrm{~mW}$ em 40 segundos de exposição; c-) dispositivo experimental à base de LEDs, potência de 50 mW, 60 segundos de exposição. O diâmetro de saída dos feixes, em cada fonte de luz, foram fixados em $8,0 \mathrm{~mm}$. 


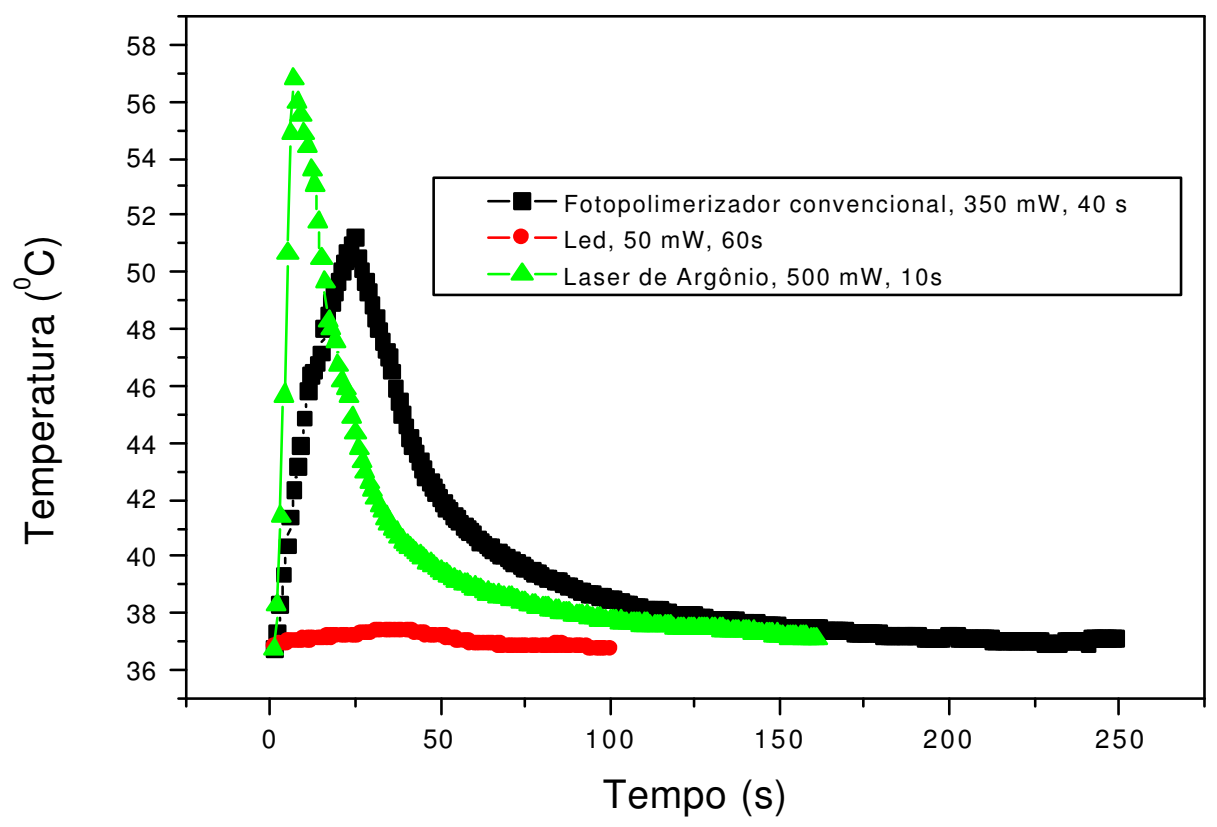

Figura 4.8 - Gráfico indicando a variação de temperatura durante a polimerização com o termistor localizado na base da restauração.

Através deste gráfico, podemos verificar que numa situação extrema de exposição pulpar, em que o profissional opte por uma restauração direta de resina composta, as variações de temperatura poderão atingir $20^{\circ} \mathrm{C}$, no caso do laser de argônio, e $15^{\circ} \mathrm{C}$, utilizando a lâmpada convencional. Estes valores são bastante significantes e as variações obtidas são superiores as temperaturas biologicamente toleráveis, podendo acarretar danos pulpares irreversíveis. [53]

Várias são as teorias utilizadas para justificar a sensibilidade dos pacientes após uma restauração direta de resina composta profunda e extensa, dentre elas o fato de a resina composta apresentar contração durante o processo de polimerização podendo causar uma modificação na pressão dentro dos túbulos dentinários pressionando os odontoblastos levando a uma sensação dolorosa. 
Outra provável possibilidade de sensibilidade relacionada ao uso das resinas compostas relaciona-se a dificuldade técnica em obter uma cavidade asséptica ou mesmo na confecção de uma restauração com um vedamento interfacial aceitável. As fendas dente-restauração são causadas também pela grande diferença de coeficiente linear de expansão térmica entre a estrutura dental e a própria resina composta fazendo com que a relação de contração e expansão dente-restauração seja diferente, gerando tensões de interface.

Temos ainda a toxicidade dos monômeros metacrilatos que não reagiram durante a polimerização do material, principalmente HEMA (hidróxi-etilmetacrilato) levando a reações inflamatórias locais.

E, seguindo o raciocínio de nossa análise térmica, podemos associar a reação inflamatória pulpar a uma grande variação na temperatura intrapulpar durante o processo de polimerização da resina composta. Quando utilizamos o fotopolimerizador convencional ou o laser de argônio podemos ultrapassar os limites térmicos biológicos do tecido pulpar estudados histogicamente por Zach e Cohen e induzir iatrogenicamente uma reação inflamatória irreversível, culminando com a necrose pulpar. 


\title{
Disposit ivos LED para polimerização de
}

\section{resinas compostas dent ais: comparação}

\author{
com out ras f ont es de luz.
}

Capítulo V: Variação de propriedades mecânicas das resinas compostas com a

exposição a agentes químicos e análise em microscopia eletrônica de varredura 
Dispositivos LED para polimerização de resinas compostas dentais: comparação com outras fontes de luz

Capítulo V - Variação de propriedades mecânicas das resinas compostas com a exposição a agentes químicos e análise em microscopia eletrônica de varredura

\section{INTRODUÇÃO}

A cavidade oral é um meio que apresenta algumas peculiaridades, principalmente em relação às variações químicas e aos esforços mecânicos.

As resinas compostas constituem-se de uma matriz polimérica acrescida de partículas cerâmicas e, são uns dos materiais mais utilizados na dentística restauradores. [43]

As propriedades dos compósitos odontológicos são enormemente influenciadas, não somente pela sua composição química, como também, pelo meio químico a que estão expostos. [19][20]

O grau de polimerização das resinas compostas tem sido um dos fatores de influência na biocompatibilidade desta categoria de materiais. Os monômeros metacrilatos que não participaram da reação de polimerização apresentam relativa citotoxidade podendo levar a inflamações pulpares. [18]

Os fluidos orais apresentam uma vasta composição de elementos químicos: ácidos produzidos pela placa bacteriana, alimentos de diversas composições, variações de $\mathrm{pH}$, entre outros. Todos estes fatores associados às complexas tensões as quais o material é submetido são capazes de promover a quebra de ligações fortes e fracas na matriz orgânica e no agente silano, responsável pela ligação da partícula cerâmica à rede polimérica. Isto leva à redução da estabilidade química e as propriedades mecânicas do material. [2][32][44][45]

Relacionado ao grau de cura obtido por uma polimerização efetiva do material está a estabilidade da matriz polimérica e a formação de bioprodutos que 
resultam da degradação. Estudos têm demonstrado que a resina composta dental é susceptível a vários modos de degradação química. [30][32][42][45]

Existem indícios de que a degradação química da resina composta se dá principalmente por difusão de moléculas e íons dos monômeros resinosos que não reagiram no processo de cura e por hidrólise do agente silano que faz a união da carga com a matriz orgânica da resina composta. [8][45]

FERRACANE e MARKER, em 1992, avaliaram o efeito da água e de uma solução aquosa com etanol a $75 \%$ sobre a resistência à fratura de quatro resinas compostas fotoativadas experimentais. Os materiais foram preparados com a fase orgânica à base de BisGMA e TEGDMA (50\%/50\%), também utilizadas como grupos controles. Em dois grupos foram inseridas partículas de quartz: G I - tamanho médio de $1 \mu \mathrm{m}, 80 \%$ em massa; e G II tamanho médio de $10 \mu \mathrm{m}, 80 \%$ em massa. Outros dois grupos contendo partículas de vidro de bário, um com tamanho médio de $2 \mu \mathrm{m}, 70 \%$ em massa e outro com tamanho médio de $12 \mu \mathrm{m}, 70 \%$ em massa. Os resultados mostraram redução estatística na resistência à fratura apenas para os corpos de prova mantidos em solução de etanol. Análises de fratura em microscopia eletrônica de varredura, após períodos de imersão de 24 horas, 2 e 14 meses, mostraram a presença de fendas para todos os materiais testados, independentemente do meio de imersão. Entretanto, maior dissolução da matriz foi observada nos corpos de prova imersos em solução de etanol. [20]

A degradação química juntamente com a cura inefetiva das resinas compostas dentais podem comprometer a estabilidade de cor dos compósitos através da incorporação de corantes nas microporosidades da matriz polimérica. Tem-se demonstrado que um maior grau de cura permite uma menor descoloração do 
Dispositivos LED para polimerização de resinas compostas dentais: comparação com outras fontes de luz

Capítulo V - Variação de propriedades mecânicas das resinas compostas com a exposição a agentes químicos e análise em microscopia eletrônica de varredura

compósito, indicando que a estabilidade química está relacionada ao grau de conversão. [24]

IMAZATU e colaboradores, em 1995, estudaram os efeitos de diferentes composições de matriz orgânica e diferentes graus de conversão na descoloração interna de resinas compostas experimentais. Os autores concluíram que: a maior quantidade de TEGDMA permitiu um maior grau de conversão e que o grau de conversão e a descoloração interna do material mostraram uma correlação inversamente proporcional, ou seja, a descoloração diminui com o aumento da conversão. Além disso, ligações duplas de carbono que não reagiram e grupamentos amina em excesso podem estar relacionados com a descoloração de resinas compostas fotoativadas. [24]

Os compósitos dentais quando submetidos a meios aquosos apresentam absorção de água nos espaços presentes entre as cadeias de polímeros. Esse inchamento pode levar a uma diminuição da força nas ligações cruzadas entre cadeias, além de atacar a interface partícula cerâmica - matriz resinosa atuando no agente silano responsável pela ligação química da fase orgânica com a fase inorgânica. A consequiência desta hidratação da resina composta é a redução de propriedades mecânicas. [3][30][42]

Algumas teorias têm sido apresentadas para explicação da quebra de ligação da partícula quando exposta a meio aquoso e corrosão da partícula vítrea, evidenciando a quebra das ligações silanizadas carga-matriz ou pela própria corrosão da carga quando exposta a uma variação de pH. [3][20][30]

SHIN AND DRUMMOND (1999) verificaram os efeitos de diversos meios de imersão na determinação de liberação de partículas cerâmicas dos compósitos 
dentais, em função do tempo de imersão em: água destilada, água deionizada e solução de etanol $50 \%$. Os pesquisadores concluíram que os meios que continham solução de etanol e água deionizada apresentaram uma maior taxa de liberação de sílica e estrôncio. Esse processo de degradação parecia ser continuado por mais de 10 meses, contrariando achados prévios da literatura. Além disso, as propriedades de resistência à fratura desses compósitos reduziam-se quando expostas aos meios citados. [42]

LEE e colaboradores analisaram os componentes liberados de três resinas compostas comerciais: Z100 (3M Dental Products Division, MN, USA), Heliomolar (Ivoclar Vivadent, NY, USA) e Marathon One (Den-Mat corporation, CA, USA); quando expostas a diferentes meios contendo: solução aquosa a $75 \%$ de etanol considerado pela FDA como solvente universal, ácido acético $(99,9 \%)$ e ácido propiônico (99\%) usualmente produzidos pelo metabolismo das bactérias da placa dental. Auxiliados por aparelhos de cromatografia e espectrômetros de massa os pesquisadores executaram um estudo qualitativo e quantitativo dos componentes liberados nas soluções, além de verificarem a tensão de ruptura nos espécimes submetidos ao teste de tração diametral. Os autores verificaram que a menor quantidade e qualidade de componentes liberados ocorreu na resina composta Z100 nos diversos meios, além disso, as propriedades de resistência à tração diametral foram menos atingidas também na resina Z100 em relação aos outros compósitos estudados. [30]

Neste capítulo, executamos um estudo sistemático da variação das propriedades de microdureza superficial e resistência à tração diametral, após a imersão de amostras de resina composta polimerizadas com laser de argônio, 
Dispositivos LED para polimerização de resinas compostas dentais: comparação com outras fontes de luz

Capítulo V - Variação de propriedades mecânicas das resinas compostas com a exposição a agentes químicos e análise em microscopia eletrônica de varredura

lâmpada halógena convencional e dispositivo à base de LEDs. Além disso, verificamos as características microscópicas e macroscópicas das superfícies fraturadas através de microscopia eletrônica de varredura. 
Dispositivos LED para polimerização de resinas compostas dentais: comparação com outras fontes de luz

Capítulo V - Variação de propriedades mecânicas das resinas compostas com a exposição a agentes químicos e análise em microscopia eletrônica de varredura

\section{MATERIAIS E MÉTODOS}

\section{Preparação das amostras}

Utilizamos neste experimento matrizes de aço inoxidável com cilindros de $8,0 \mathrm{~mm}$ de diâmetro e profundidade de $2,0 \mathrm{~mm}$. Na base de parte cilíndrica, um recorte de tira de poliéster foi acomodada para permitir uma maior lisura na superfície oposta à iluminada.

A resina composta (Z-100, cor A3, <3M do Brasil $>$ ) foi inserida e acomodada em uma só camada e, sobre esta, foi colocada uma matriz de poliéster e outra placa metálica homogênea e lisa foi sobreposta pressionando mecanicamente todo o sistema, com pressão equivalente para todos os grupos, para permitir uma maior padronização de espessura dos corpos de prova.

Em seguida, cada espécime foi polimerizado individualmente, pelas três fontes de luz operando nos parâmetros normalmente recomendados para os respectivos aparelhos:

- Fotopolimerizador convencional - 40 espécimes de resina composta, curados com lâmpada halógena (fotopolimerizador convencional $<200$ R, $\mathrm{K} \& \mathrm{M}$, Brasil>) por um período de 40 segundos com potência aproximada de $350 \mathrm{~mW}$ e intensidade de $700 \mathrm{~mW} / \mathrm{cm}^{2}$;

- Laser de argônio (linha 488 nm) - 40 espécimes foram curados por um período de 10 segundos com laser de argônio (INNOVA 100, Coherent, EUA), potência de $500 \mathrm{~mW}$ e $1 \mathrm{~W} / \mathrm{cm}^{2}$ de intensidade; 
Dispositivos LED para polimerização de resinas compostas dentais: comparação com outras fontes de luz

Capítulo V - Variação de propriedades mecânicas das resinas compostas com a exposição a agentes químicos e análise em microscopia eletrônica de varredura

- Dispositivo à base de LEDs azuis- 80 espécimes foram curados em tempos de exposição de 40 e 60 segundos.O dispositivo à base de LEDs possui uma potência média de $50 \mathrm{~mW}$ e intensidade aproximada de $100 \mathrm{~mW} / \mathrm{cm}^{2}$.

A exposição da resina composta às fontes de luz foi executada com a ponteira do dispositivo em contato com a superfície de resina composta protegida com uma tira de poliéster. Esta técnica não foi executada quanto à exposição ao laser de argônio, pois a determinação do diâmetro do feixe é dada pela regulação da distância fibra óptica - resina composta. O diâmetro de saída do feixe dos aparelhos foi padronizado em $8 \mathrm{~mm}$.

Após a polimerização, os espécimes foram divididos em grupos de oito espécimes submetidos à imersão nas seguintes soluções: água destilada, solução de álcool etílico 50\%, solução de ácido acético à 99,9 \%, solução de ácido propiônico à 96,3 \%. As amostras ficaram em imersão nas soluções supracitadas, em frascos de vidro âmbar, durante um período de 30 dias, mantidos a uma temperatura média de $37^{\circ} \mathrm{C}\left( \pm 0,5^{\circ} \mathrm{C}\right)$. Um grupo controle manteve os espécimes sem a presença de meio líquido também na temperatura de $37^{\circ} \mathrm{C}\left( \pm 0,5^{\circ} \mathrm{C}\right)$. Mostramos resumidamente todos os grupos na tabela 5.1. 
Tabela 5.1

\begin{tabular}{|c|c|c|c|c|c|}
\hline \multicolumn{6}{|c|}{ GRUPOS PARA EXPERIMENTO QUÍMICO } \\
\hline Controle & $\begin{array}{c}\text { Água } \\
\text { Destilada }\end{array}$ & $\begin{array}{c}\text { Sol. } \\
\text { álcool 50 } \\
\text { \% }\end{array}$ & $\begin{array}{c}\text { Sol. de } \\
\text { Ac. } \\
\text { Acético }\end{array}$ & $\begin{array}{c}\text { Sol. de Ac. } \\
\text { Propiônico }\end{array}$ \\
\hline $\begin{array}{c}\text { Laser de Argônio, } \\
500 \mathrm{~mW}, 10 \mathrm{~s} \text { de } \\
\text { exposição. }\end{array}$ & G-Ia & G-Ib & G-Ic & G-Id & G-Ie \\
\hline $\begin{array}{c}\text { Lâmpada Halógena, } \\
\text { 350 mW, 40 s } \\
\text { exposição. }\end{array}$ & G-IIa & G-IIb & G-Iic & G-IId & G-IIe \\
\hline $\begin{array}{c}\text { Dispositivo } \\
\text { experimental LED, } \\
50 \text { mW, 60 s de } \\
\text { exposição. }\end{array}$ & G-IIIa & G-IIIb & G-IIIc & G-IIId & G-IIIe \\
\hline $\begin{array}{c}\text { Dispositivo } \\
\text { experimental LED, } \\
50 \text { mW, 40 s de } \\
\text { exposição. }\end{array}$ & G-IVa & G-IVb & G-Ivc & G-IVd & G-IVe \\
\hline
\end{tabular}

Cada grupo é composto de um algarismo romano e de uma letra, onde os algarismos romanos referem-se às fontes de luz: I Laser de argônio; II - Lâmpada halógena; III - LED 60s de exposição e IV- LED 40s de exposição; e as letras referem-se aos meios submetidos: a- controle, b- água destilada, esolução aquosa de álcool etílico 50 \%, d- solução de ácido acético, e- solução de ácido propiônico.

Após os trinta dias de imersão nos agentes químicos supracitados, as amostras ficaram imersas mais trinta dias em água destilada a temperatura média de $37^{\circ} \mathrm{C}( \pm$ $\left.0,5^{\circ} \mathrm{C}\right)$.

Para uma melhor caracterização e comparação da eficiência de polimerização da resina composta curada com os três aparelhos supracitados e da ação de cada agente químico nas resinas compostas, executou-se um estudo da microdureza Vickers da superfície iluminada e da face oposta à iluminação nos espécimes. 
Dispositivos LED para polimerização de resinas compostas dentais: comparação com outras fontes de luz

Capítulo V - Variação de propriedades mecânicas das resinas compostas com a exposição a agentes químicos e análise em microscopia eletrônica de varredura

\section{$\underline{\text { Análise comparativa da Microdureza Vickers }}$}

Cada grupo de espécimes foi cuidadosamente retirado do recipiente, com auxílio de uma pinça clínica. Os espécimes foram mantidos em recipiente escuro para proteger da exposição à luz extra, durante 48 horas.

Posicionamos o espécime de resina composta no Microdurômetro <mhp 160 Microhardness Tester> e, com auxílio da lente de aumento, determinamos uma área central do espécime para receber as marcas do identador. O microdurômetro utilizado está mostrado na figura 3.1 do capítulo 3.

Utilizamos um total de cinco amostras de cada grupo e, em cada superfície, foram confeccionadas três penetrações utilizando uma carga relativa a 50 gramas por 30 segundos.

A marca obtida pelo diamante Vickers, em cada penetração, foi identificada e obtivemos as médias das diagonais que foram submetidas a seguinte fórmula matemática para obtenção do número de dureza Vickers (mhp - Microhardness Tester - Instruction Manual).

$$
\text { MHV }=(1854,4 * \mathbf{P}) \div \mathbf{d}^{2}\left(\mathrm{Kg} / \mathrm{mm}^{2}\right)
$$

Onde, $P$ é a carga aplicada em gramas e $d$ a média das diagonais em $\mu \mathrm{m}$.

Verificou-se o valor de dureza Vickers para a face diretamente iluminada (superfície de topo) e também para a face oposta à iluminação (base) para verificação da diminuição desta propriedade nas regiões superficiais expostas, em função do meio de imersão e da fonte de luz utilizada para a polimerização. 
Dispositivos LED para polimerização de resinas compostas dentais: comparação com outras fontes de luz

Capítulo V - Variação de propriedades mecânicas das resinas compostas com a exposição a agentes químicos e análise em microscopia eletrônica de varredura

Os valores de microdureza obtidos foram analisados estatisticamente

utilizando o teste ANOVA para determinação da variância e o teste de Tukey com grau de significância de 5\%. 
Dispositivos LED para polimerização de resinas compostas dentais: comparação com outras fontes de luz

Capítulo V - Variação de propriedades mecânicas das resinas compostas com a exposição a agentes químicos e análise em microscopia eletrônica de varredura

\section{Ensaio de Tração Diametral}

Utilizaram-se, para este ensaio, 08 (oito) espécimes de cada grupo após os 30 (trinta) dias de imersão nos agentes químicos e mais 30 (trinta) dias de imersão em água destilada, em uma temperatura média de $37^{\circ} \mathrm{C}\left( \pm 0,5^{\circ} \mathrm{C}\right)$.

Este ensaio foi executado em uma máquina de ensaio mecânico universal (Material Test System - MTS 810 - MTS, MN, USA), nas dependências da Faculdade de Odontologia, UNESP - Araraquara.

Cada espécime foi posicionado em uma base de metal, com o diâmetro na vertical e o braço hidráulico superior foi posicionado tocando a amostra. A velocidade de deslocamento do braço hidráulico foi ajustada para $1 \mathrm{~mm} / \mathrm{min}$, de acordo com o recomendado pela literatura. Os valores de força aplicados foram registrados pelo microcomputador acoplado ao equipamento de ensaio até a ruptura do espécime. O posicionamento do espécime e a aplicação da força estão demonstrados na figura esquemática 5.1:
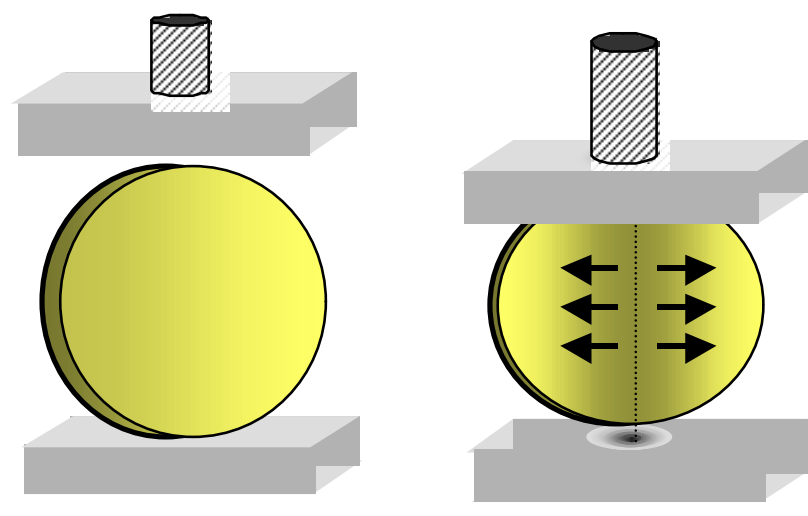

Figura 5.1 - Figura esquemática do ensaio de tração diametral 
Dispositivos LED para polimerização de resinas compostas dentais: comparação com outras fontes de luz

Capítulo V - Variação de propriedades mecânicas das resinas compostas com a exposição a agentes químicos e análise em microscopia eletrônica de varredura

No ensaio de tração diametral, também referido por teste de compressão diametral, representado esquematicamente na figura anterior, quando a carga é aplica ao espécime, são geradas forças de tração (indicado pelas setas) que tendem a fraturar o espécime no plano de fratura (linha pontilhada) correspondente ao diâmetro do espécime.

Nesta situação, os valores de carga de compressão aplicados são proporcionais aos valores de tensão de tração, seguindo a fórmula:

$$
\tau=2 \mathbf{P} \div(\boldsymbol{\pi} * \mathbf{D} * \mathbf{t})
$$

Onde $P$ é o valor da carga de ruptura (em Newton), $D$ é o diâmetro do espécime (em $\mathrm{mm}), t$ é a espessura do espécime (em $\mathrm{mm})$, para a obtenção do valor de tensão de ruptura $\tau$ (em Mpa).

Após a ruptura do espécime, os fragmentos foram resgatados e armazenados em recipientes fechados revestidos internamente com algodão para preservar as características da superfície fraturada e evitar impactos que pudessem modificar micro ou macromorfologicamente esta superfície. Os recipientes foram acondicionados em estufa e mantidos a $37^{\circ} \mathrm{C}\left( \pm 0,5^{\circ} \mathrm{C}\right)$.

Os valores de tensões de ruptura foram analisados estatisticamente em variância utilizando o teste ANOVA e aplicado o teste de Tukey adotando um grau de significância de 5\%. 


\section{Microscopia Eletrônica de Varredura}

As superfícies de fratura dos fragmentos, obtidos após o ensaio de tração diametral, foram analisadas com auxílio de microscópio eletrônico de varredura (Digital Scanning Microscopy - DSM 960, Zeiss, German) em busca de evidências que possam caracterizar diferenças entre as fontes de luz utilizadas para a polimerização ou que determinem características de fraturas inerentes aos danos causados pelos meios de imersão submetidos.

O microscópio eletrônico de varredura é uma poderosa ferramenta da ciência para o estudo de quantitativo e qualitativo dos mais diversos materiais, análise da morfologia superficial com a possibilidade de resoluções nanométricas.

Para análise em microscópio eletrônico de varredura os espécimes foram fixados em porta amostras através de esmalte de unha incolor (Figura 5.2) dois dias antes da análise.

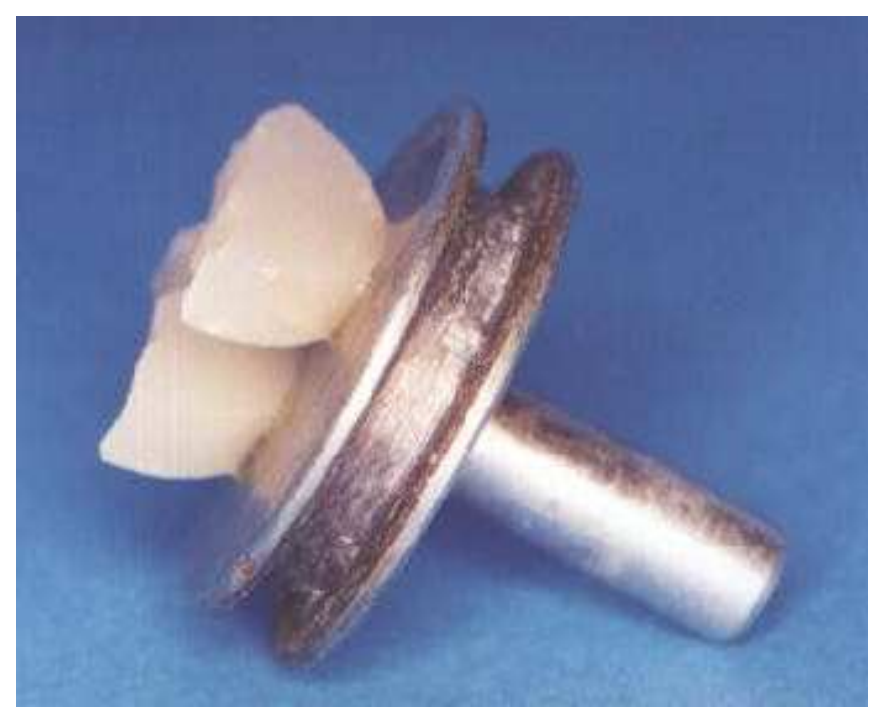

Figura 5.2 - Amostras fraturadas fixadas em porta amostra. 
Dispositivos LED para polimerização de resinas compostas dentais: comparação com outras fontes de luz

Capítulo V - Variação de propriedades mecânicas das resinas compostas com a exposição a agentes químicos e análise em microscopia eletrônica de varredura

Para evitar danos na superfície do compósito devido ao alto conteúdo energético do feixe eletrônico, utilizamos o equipamento de "sputtering" ( Balzers SCD 050 Sputer Coater, Balzers, German) para aplicação de cobertura nas amostras com fina camada de ouro de $20 \mathrm{~nm}$. O equipamento e as amostras após a deposição do ouro estão mostradas nas figuras 5.3 e 5.4 .

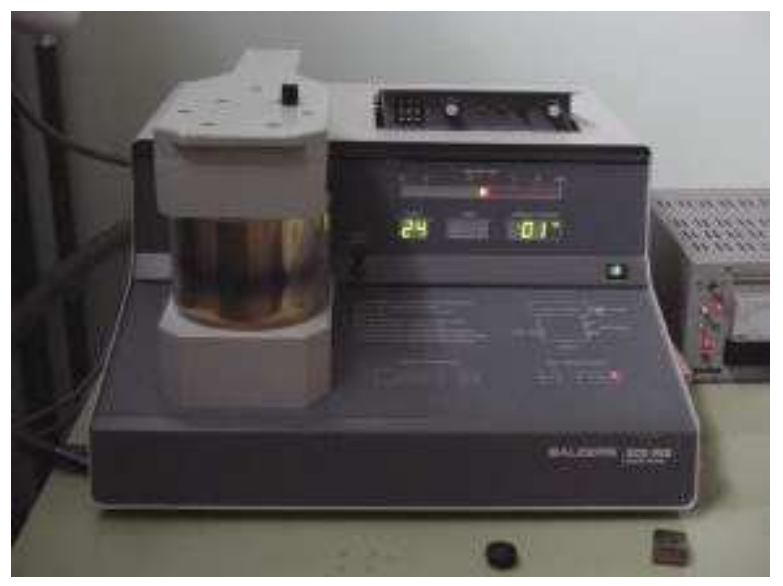

Figura 5.3 - Equipamento de "sputtering"

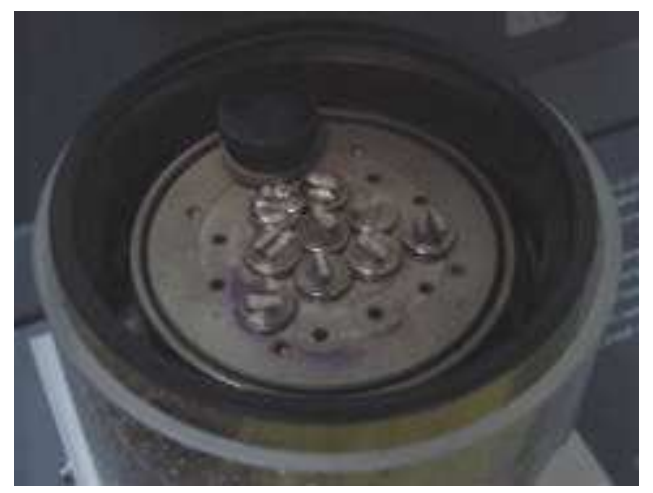

Figura 5.4 - Amostras após a metalização com fina camada de ouro.

Após a deposição da fina camada de ouro, os porta amostras foram cuidadosamente colocados no carrinho contido na câmara de amostras. A câmara de amostras consiste em um espaço evacuado, abaixo das lentes objetivas, que contém o 
Dispositivos LED para polimerização de resinas compostas dentais: comparação com outras fontes de luz

Capítulo V - Variação de propriedades mecânicas das resinas compostas com a exposição a agentes químicos e análise em microscopia eletrônica de varredura

carro de amostras com todos os seus movimentos, os detectores de sinal de elétrons, os detectores de raios $\mathrm{X}$, e uma linha de vácuo para a bomba principal de vácuo.

O carrinho onde se encontram as amostras permite uma regulação da posição da amostra a ser analisada através de rotação, translação nos eixos x e y, além da possibilidade de inclinação da amostra para facilitar a tomada de sinais pelo detector.

Após o fechamento da camada de amostras, espera-se a retomada do vácuo que na câmara de amostra deverá estar em torno de $10^{-4} \mathrm{mmHg}$, e na região da geração do feixe de elétrons deverá estar a $10^{-8} \mathrm{mmHg}$ (esta variável depende da fonte de elétrons: tungstênio, hexaboreto de lantânio etc).

As figuras 5.5 e 5.6 mostram as duas partes principais do microscópio eletrônico utilizado: a coluna eletrônica (figura 5.5) e $\quad$ o controlador $\quad$ e microprocessador de informações fornecidas pelo detector (figura 5.6).

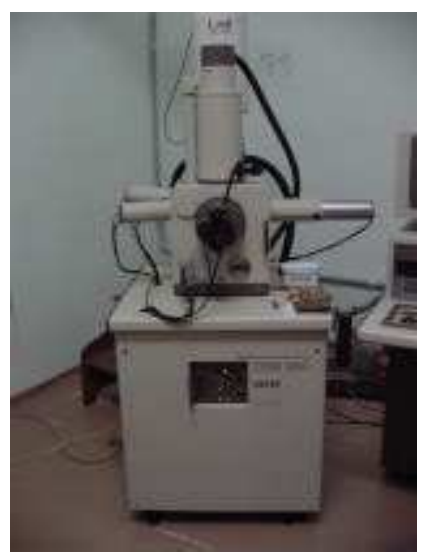

Figura $5.5-$ Figura mostrando a coluna de elétrons do MEV.

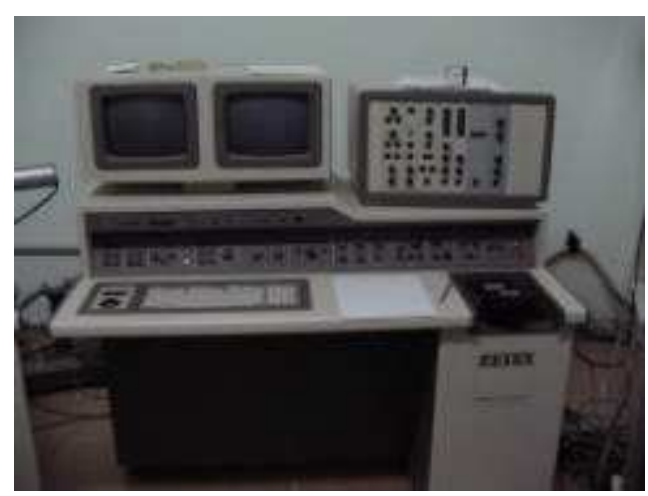

Figura 5.6 - Figura mostrando o controlador e microprocessador do MEV. 


\section{RESULTADOS E DISCUSSÕES}

\section{$\underline{\text { Análise da Microdureza Vickers }}$}

Os valores médios de microdureza encontrados na superfície diretamente iluminada (topo) e na face oposta à iluminação (base) estão apresentados nas tabelas 5.2, 5.3, 5.4, 5.5; e em forma de gráficos nas figuras 5.7, 5.8, 5.9, 5.10.

Na figura 5.7 e 5.9 os resultados de microdureza obtidos no topo e na base estão indicados em função da fonte de luz utilizada para polimerizar os espécimes (eixo x), e nas figuras 5.8 e 5.10 os resultados no topo e na base estão indicados em função do meio de imersão.

Tabela 5.2 - Valores de microdureza do grupo controle

\begin{tabular}{|c|c|c|c|c|}
\hline \multirow{5}{*}{ GRUPO } & \multicolumn{3}{|c|}{ TOPO } & $\begin{array}{c}\text { Desvio } \\
\text { Padrão }\end{array}$ \\
\cline { 2 - 5 } & MÉDIA & $\begin{array}{c}\text { Desvio } \\
\text { Padrão }\end{array}$ & MÉDIA & 7,3 \\
\hline $\begin{array}{c}\text { G-Ia } \\
\text { Laser de } \\
\text { Argônio } \\
(10 \mathrm{~s})\end{array}$ & 130,7 & 2,2 & 111,7 & \\
\hline $\begin{array}{c}\text { G-IIa } \\
\text { Lâmpada } \\
\text { Halógena } \\
(40 \mathrm{~s})\end{array}$ & 124,4 & 4,5 & 110,4 & 6,9 \\
$\begin{array}{c}\text { G-IIIa } \\
\text { LED } \\
60 \mathrm{~s}\end{array}$ & 124,3 & 3,0 & 107,1 & 3,3 \\
\hline $\begin{array}{c}\text { G-IVb } \\
\text { LED } \\
40 \mathrm{~s}\end{array}$ & 121,9 & 3,6 & 101,4 & 3,8 \\
\hline
\end{tabular}


Dispositivos LED para polimerização de resinas compostas dentais: comparação com outras fontes de luz

Capítulo V - Variação de propriedades mecânicas das resinas compostas com a exposição a agentes químicos e análise em microscopia eletrônica de varredura

Tabela 5.3: Valores de microdureza do grupo de imersão em água destilada.

\begin{tabular}{|c|c|c|c|c|}
\hline \multicolumn{5}{|c|}{ Tabela dos valores médios MHV - ÁGUA } \\
\hline \multirow{2}{*}{ GRUPO } & \multicolumn{3}{|c|}{ TOPO } & \multicolumn{2}{c|}{ BASE } \\
\cline { 2 - 5 } & MÉDIA & $\begin{array}{c}\text { Desvio } \\
\text { Padrão }\end{array}$ & MÉDIA & $\begin{array}{c}\text { Desvio } \\
\text { Padrão }\end{array}$ \\
\hline $\begin{array}{c}\text { G-Ib } \\
\text { Laser de } \\
\text { Argônio } \\
(10 \mathrm{~s})\end{array}$ & 109,9 & 6,1 & 105,5 & 7,2 \\
\hline $\begin{array}{c}\text { G-IIb } \\
\text { Lâmpada } \\
\text { Halógena } \\
\text { (40 s) }\end{array}$ & 103,1 & 3,5 & 98,8 & 2,3 \\
\hline $\begin{array}{c}\text { G-IIIb } \\
\text { LED } \\
60 \mathrm{~s}\end{array}$ & 101,0 & 3,3 & 96,4 & 2,4 \\
\hline $\begin{array}{c}\text { G-IVb } \\
\text { LED } \\
40 \mathrm{~s}\end{array}$ & 95,4 & 3,0 & 92,7 & 2,6 \\
\hline
\end{tabular}

Tabela 5.4: Valores de microdureza do grupo de imersão em álcool $50 \%$.

\begin{tabular}{|c|c|c|c|c|}
\hline \multicolumn{5}{|c|}{ Tabela dos valores médios MHV - ÁLCOOL 50 \% } \\
\hline \multirow{2}{*}{ GRUPO } & \multicolumn{3}{|c|}{ TOPO } & \multicolumn{2}{c|}{ BASE } \\
\cline { 2 - 5 } & MÉDIA & $\begin{array}{c}\text { Desvio } \\
\text { Padrão }\end{array}$ & MÉDIA & $\begin{array}{c}\text { Desvio } \\
\text { Padrão }\end{array}$ \\
\hline $\begin{array}{c}\text { G-Ic } \\
\text { Laser de } \\
\text { Argônio } \\
(10 \mathrm{~s})\end{array}$ & 98,0 & 3,1 & 93,3 & 1,9 \\
\hline $\begin{array}{c}\text { G-IIc } \\
\text { Lâmpada } \\
\text { Halógena } \\
(40 \mathrm{~s})\end{array}$ & 96,6 & 3,3 & 93,2 & 4,0 \\
\hline $\begin{array}{c}\text { G-IIIc } \\
\text { LED } \\
60 \mathrm{~s}\end{array}$ & 95,6 & 2,8 & 92,3 & 2,7 \\
\hline $\begin{array}{c}\text { G-IVc } \\
\text { LED } \\
40 \mathrm{~s}\end{array}$ & 94,9 & 5,1 & 90,0 & 3,6 \\
\hline
\end{tabular}


Dispositivos LED para polimerização de resinas compostas dentais: comparação com outras fontes de luz

Capítulo V - Variação de propriedades mecânicas das resinas compostas com a exposição a agentes químicos e análise em microscopia eletrônica de varredura

Tabela 5.5: Valores de microdureza do grupo de imersão em ácido acético.

\begin{tabular}{|c|c|c|c|c|}
\hline \multicolumn{5}{|c|}{ Tabela dos valores médios MHV - Ac. ACÉTICO } \\
\hline \multirow{2}{*}{ GRUPO } & \multicolumn{3}{|c|}{ TOPO } & \multicolumn{2}{c|}{ BASE } \\
\cline { 2 - 5 } & MÉDIA & $\begin{array}{c}\text { Desvio } \\
\text { Padrão }\end{array}$ & MÉDIA & $\begin{array}{c}\text { Desvio } \\
\text { Padrão }\end{array}$ \\
\hline $\begin{array}{c}\text { G-Id } \\
\text { Laser de } \\
\text { Argônio } \\
\text { (10 s) }\end{array}$ & 99,8 & 1,5 & 97,1 & 0,8 \\
\hline $\begin{array}{c}\text { G-IId } \\
\text { Lâmpada } \\
\begin{array}{c}\text { Halógena } \\
\text { (40 s) }\end{array}\end{array}$ & 101,4 & 5,1 & 98,5 & 3,3 \\
\hline $\begin{array}{c}\text { G-IIId } \\
\text { LED } \\
60 \mathrm{~s}\end{array}$ & 97,6 & 4,7 & 93,1 & 2,4 \\
\hline $\begin{array}{c}\text { G-IVd } \\
\text { LED } \\
40 \mathrm{~s}\end{array}$ & 94,6 & 1,0 & 91,8 & 4,2 \\
\hline
\end{tabular}

Tabela 5.6: Valores de microdureza do grupo de imersão em ácido propiônico.

\begin{tabular}{|c|c|c|c|c|}
\hline \multicolumn{5}{|c|}{ Tabela dos valores médios MHV - Ac. PROPIÔNICO } \\
\hline \multirow{2}{*}{ GRUPO } & \multicolumn{3}{|c|}{ TOPO } & \multicolumn{2}{c|}{ BASE } \\
\cline { 2 - 5 } & MÉDIA & \multicolumn{1}{|c|}{$\begin{array}{c}\text { Desvio } \\
\text { Padrão }\end{array}$} & MÉDIA & $\begin{array}{c}\text { Desvio } \\
\text { Padrão }\end{array}$ \\
\hline $\begin{array}{c}\text { G-Ie } \\
\text { Laser de } \\
\text { Argônio } \\
(10 \mathrm{~s})\end{array}$ & 106,7 & 3,6 & 98,5 & 1,8 \\
\hline $\begin{array}{c}\text { G-Iie } \\
\text { Lâmpada } \\
\text { Halógena } \\
(40 \mathrm{~s})\end{array}$ & 101,4 & 4,5 & 96,5 & 3,0 \\
\hline $\begin{array}{c}\text { G-IIIe } \\
\text { LED } \\
60 \mathrm{~s}\end{array}$ & 97,9 & 1,4 & 93,7 & 1,2 \\
\hline $\begin{array}{c}\text { G-IVe } \\
\text { LED } \\
40 \mathrm{~s}\end{array}$ & 92,2 & 2,6 & 87,3 & 1,8 \\
\hline
\end{tabular}


Dispositivos LED para polimerização de resinas compostas dentais: comparação com outras fontes de luz

Capítulo V - Variação de propriedades mecânicas das resinas compostas com a exposição a agentes químicos e análise em microscopia eletrônica de varredura

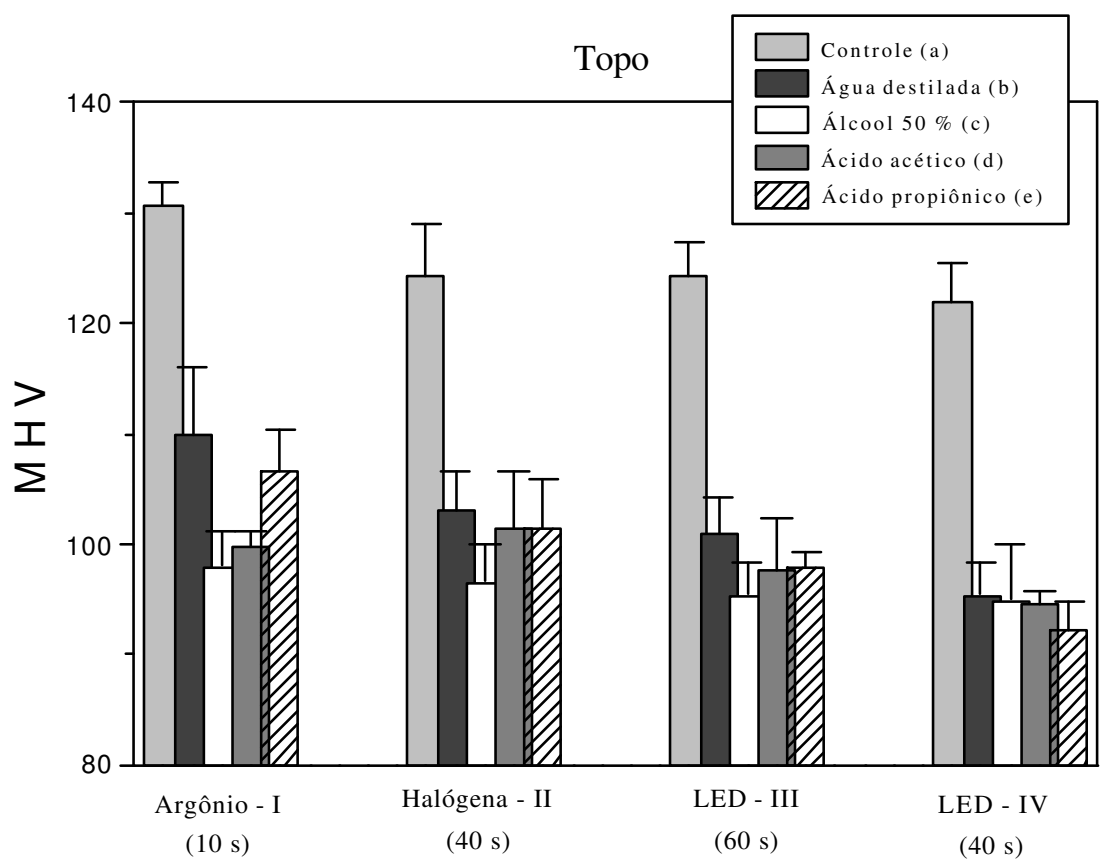

Fontes de Luz

Figura 5.7 - Gráfico de MHV, no topo, em função da fonte de luz.

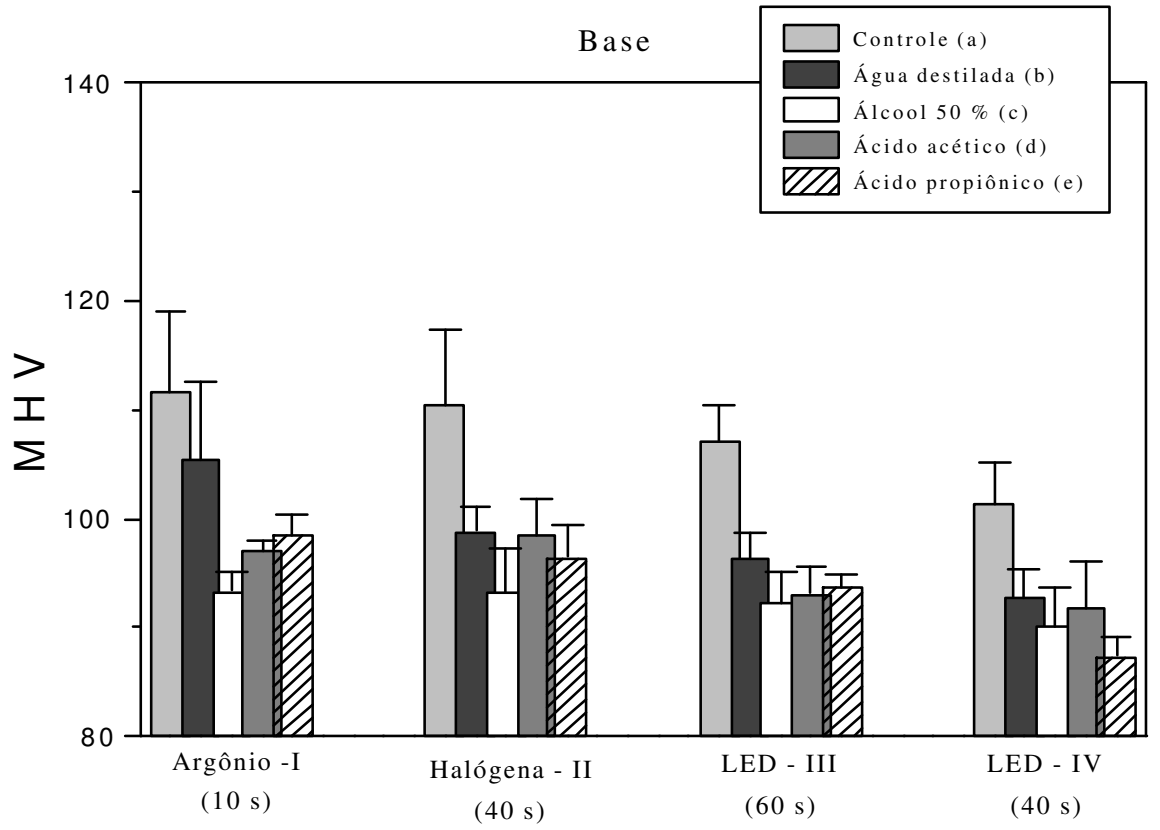

Fontes de Luz

Figura 5.8 - Gráfico de MHV, na base, em função da fonte de luz. 
Dispositivos LED para polimerização de resinas compostas dentais: comparação com outras fontes de luz

Capítulo V - Variação de propriedades mecânicas das resinas compostas com a exposição a agentes químicos e análise em microscopia eletrônica de varredura

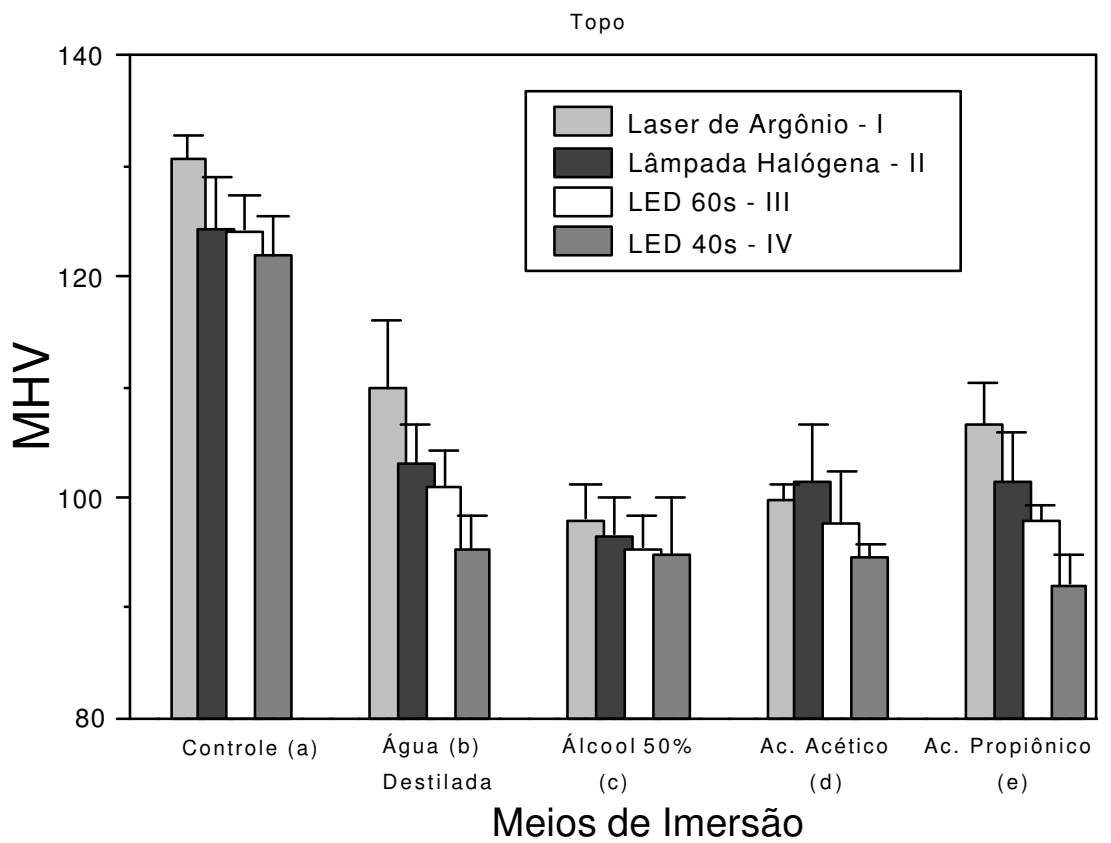

Figura 5.9 - Gráfico de MHV, no topo, em função do meio de armazenagem.

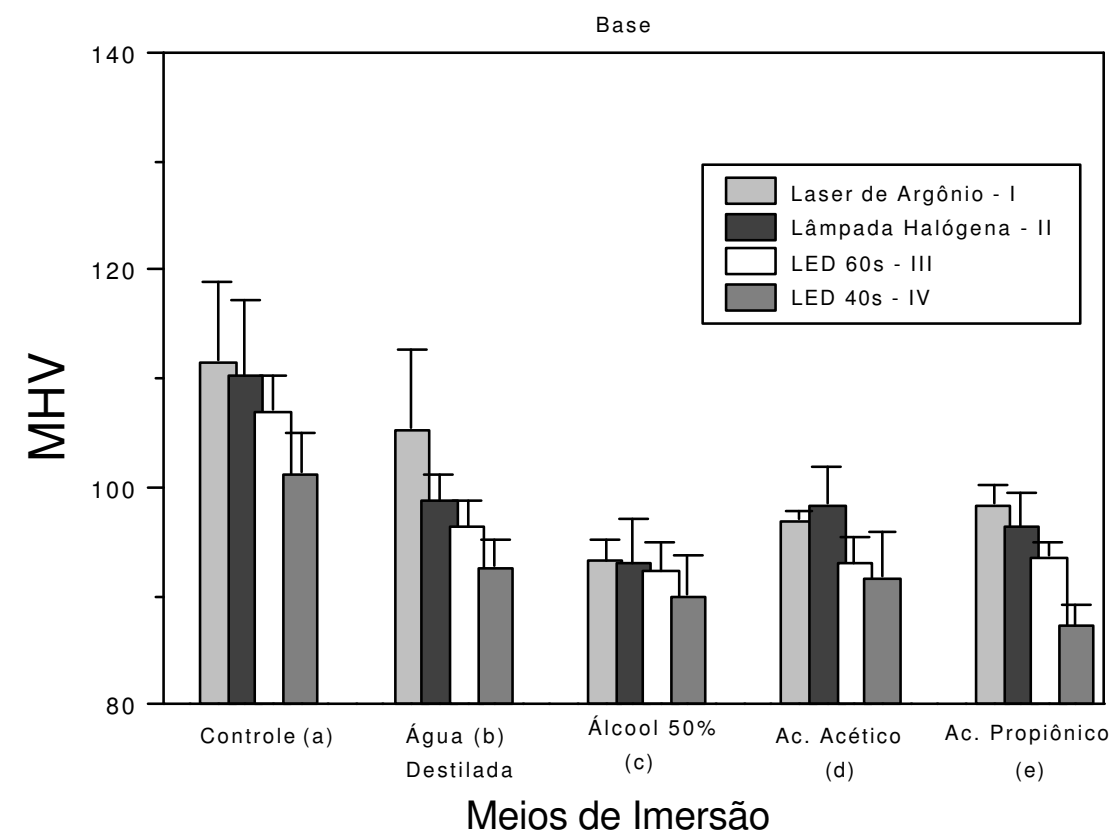

Figura 5.10 - Gráfico de MHV, na base, em função do meio de armazenagem. 
Dispositivos LED para polimerização de resinas compostas dentais: comparação com outras fontes de luz

Capítulo V - Variação de propriedades mecânicas das resinas compostas com a exposição a agentes químicos e análise em microscopia eletrônica de varredura

Após a análise estatística dos dados observamos os seguintes aspectos principais, em relação aos valores obtidos no topo (superfície do espécime diretamente irradiada):

1. Quando o fator de variação foi a fonte de luz utilizada encontramos o valor crítico de $2,7( \pm 0,7)$ e as médias para cada fonte de luz estão dispostos na tabela 5.7.

Tabela 5.7: Médias MHV obtidas com cada fonte de luz

\begin{tabular}{|c|c|}
\hline Fonte de Luz & Médias (MHV) \\
Laser de Argônio - I & 109,0 \\
\hline Lâmpada Halógena - II & 105,4 \\
\hline Led 60s - III & 103,3 \\
Led 40s - IV & 99,8 \\
\hline
\end{tabular}

Através destes valores podemos verificar que a microdureza obtida na polimerização com o laser de argônio em um período de exposição de 10 segundos foi estatisticamente superior aos valores médios de dureza obtidos com as demais fontes. Os valores obtidos com a lâmpada halógena e com o dispositivo a base de LED foram iguais estatisticamente.

2. Quando o fator de variação foi o meio de armazenagem, o valor crítico de Tukey encontrado foi de $3,2 \notin 0,8)$. Os valores médios de microdureza estão dispostos na tabela 5.7. 
Dispositivos LED para polimerização de resinas compostas dentais: comparação com outras fontes de luz

Capítulo V - Variação de propriedades mecânicas das resinas compostas com a exposição a agentes químicos e análise em microscopia eletrônica de varredura

Tabela 5.8: Médias MHV obtidas em cada meio de armazenagem

\begin{tabular}{|c|c|}
\hline Meio de Armazenagem & Média MHV \\
\hline Controle - a & 125,3 \\
\hline Água destilada - b & 102,3 \\
\hline Sol. Álcool - c & 96,2 \\
\hline Sol Ácido Acético - d & 98,4 \\
\hline Sol Ácido Propiônico - e & 99,6 \\
\hline
\end{tabular}

Através destes dados, verificamos que houve uma redução na microdureza estatisticamente significante em todos os meios de armazenagem quando comparados ao grupo controle (a) no qual a leitura de microdureza foi executado 48 horas após a polimerização, sem ser submetido a nenhum meio de armazenagem líquido.

Os grupos que apresentaram a maior redução da microdureza Vickers foram os que apresentaram armazenagem em solução aquosa de álcool etílico e em solução de ácido acético.

Para as médias obtidas na superfície oposta à irradiação (base), quando a fonte de luz foi o fator de variação os grupos de laser de argônio (I) e de lâmpada halógena (II) apresentaram-se estatisticamente iguais e superiores aos grupos de LED 60s (III) e LED 40s (IV). E, quando o fator variante foi o meio de armazenagem, o grupo controle foi estatisticamente superior aos demais e os meios que apresentaram maior redução foram: solução de álcool etílico, ácido acético e ácido propiônico.

Os resultados mostram que todos os meios utilizados levam a considerável redução da microdureza Vickers da resina composta. A redução relativa da 
ispositivos LED para polimerização de resinas compostas dentais: comparação com outras fontes de luz

Capítulo V - Variação de propriedades mecânicas das resinas compostas com a exposição a agentes químicos e análise em microscopia eletrônica de varredura

microdureza parece ser semelhante para todas as fontes, sendo discretamente maior para a resina composta polimerizada com o dispositivo LED em $40 \mathrm{~s}$ de irradiação. Desta mesma maneira, a microdureza obtida com o laser de argônio mostra-se discretamente superior.

Estes resultados mostram a estabilidade da estrutura físico-química das resinas compostas quando expostas a agentes químicos agressivos. O agente químico certamente está desestruturando a cadeia polimérica ou incorporando-se ao material, promovendo o afastamento relativo das cadeias e, conseqüentemente, enfraquecendo as ligações químicas. Estes fatores levam a perda de coesão das moléculas e conseqüente diminuição da dureza.

Dentre os variados meios expostos, o mais agressivo parece ser oálcool 50\%, no entanto, a variância dos dados é relativamente intensa para uma afirmação mais precisa.

É importante verificar que dentro dos vários meios de armazenagem, há uma aparente equivalência entre as fontes de luz usadas, de modo que mesmo o dispositivo à base de LEDs, operando em intensidades inferiores, apresenta-se apenas discretamente inferior ao laser de argônio e a lâmpada comum. 


\section{$\underline{\text { Análise da Tensão de Ruptura }}$}

Os valores de tensão obtidos no ensaio de tração diametral estão dispostos na tabela 5.9, e em forma de gráficos nas figuras 5.11 e 5.12 .

Tabela 5.9: Valores médios de tensão de ruptura

\begin{tabular}{|c|c|c|c|c|c|c|c|c|}
\hline \multicolumn{9}{|c|}{ MÉDIA DE TENSÃO DE RUPTURA } \\
\hline GRUPOS & $\begin{array}{l}\text { Lase } \\
\text { Arg }\end{array}$ & & $\begin{array}{l}\text { Lâm } \\
\text { Haló }\end{array}$ & & $\begin{array}{l}\text { LI } \\
60\end{array}$ & & $\overline{\mathbf{L I}}$ & \\
\hline & Média & D. P. & Média & D. P. & Média & D. P. & Média & D. P. \\
\hline Controle & 60,2 & 3,5 & 50,3 & 11,1 & 51,2 & 8,9 & 58,7 & 10,3 \\
\hline $\begin{array}{c}\text { Água } \\
\text { destilada }\end{array}$ & 48,7 & 6,4 & 41,7 & 6,1 & 45,4 & 5,4 & 48,7 & 6,7 \\
\hline $\begin{array}{l}\text { Álcool } \\
50 \%\end{array}$ & 39,1 & 8,3 & 32,2 & 4,8 & 35,2 & 3,2 & 34,7 & 2,9 \\
\hline $\begin{array}{l}\text { Ácido } \\
\text { Acético }\end{array}$ & 37,7 & 5,5 & 38,4 & 5,4 & 34,5 & 4,1 & 33,1 & 4,7 \\
\hline $\begin{array}{c}\text { Ácido } \\
\text { Propiônico }\end{array}$ & 38,3 & 10,1 & 37,2 & 10,1 & 38,0 & 7,5 & 41,6 & 4,9 \\
\hline
\end{tabular}


Dispositivos LED para polimerização de resinas compostas dentais: comparação com outras fontes de luz

Capítulo V - Variação de propriedades mecânicas das resinas compostas com a exposição a agentes químicos e análise em microscopia eletrônica de varredura

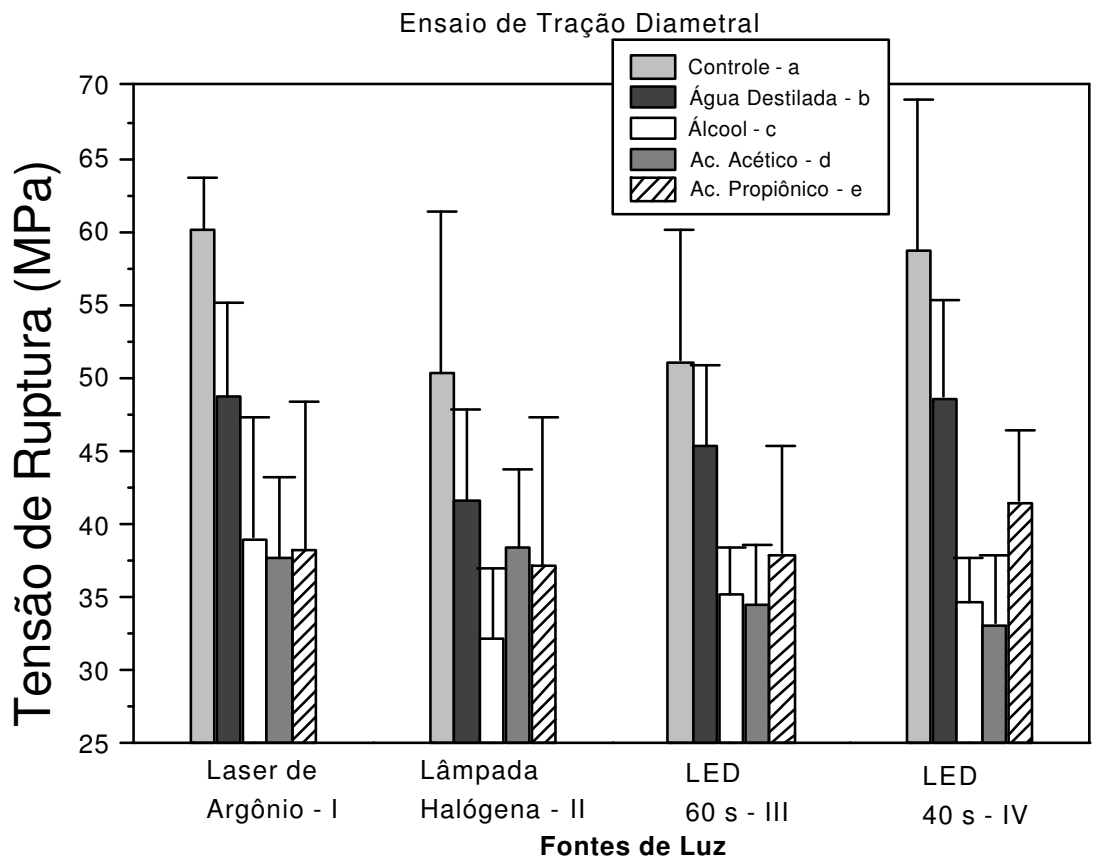

Figura 5.11 - Valores médios de tensão em função da fonte de luz.

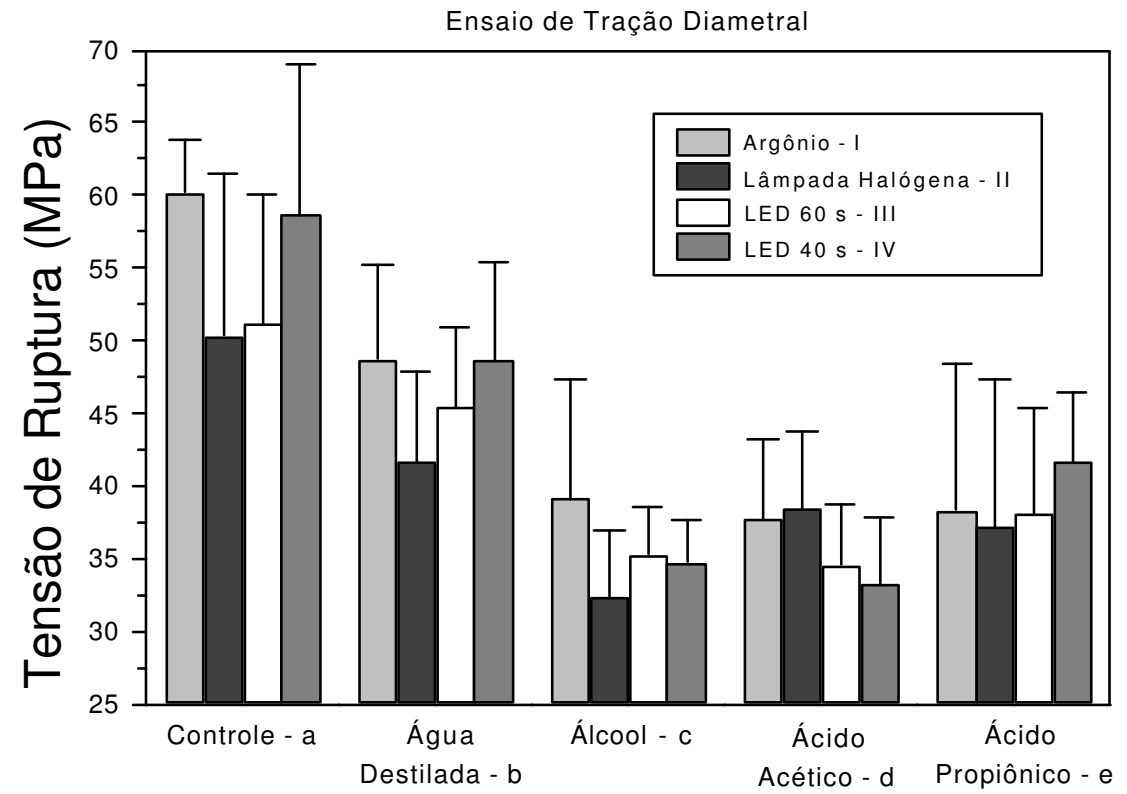

Figura 5.12 - Valores médios de tensão em função do meio de armazenagem. 
Dispositivos LED para polimerização de resinas compostas dentais: comparação com outras fontes de luz

Capítulo V - Variação de propriedades mecânicas das resinas compostas com a exposição a agentes químicos e análise em microscopia eletrônica de varredura

Os resultados foram analisados estatisticamente, e quando o fator de variação é a fonte de luz obtiveram-se as médias descritas na tabela 5.10, e o valor crítico calculado foi 3,9.

Tabela 5.10: Médias de tensão de ruptura para as fontes de luz

\begin{tabular}{|c|c|}
\hline \multicolumn{2}{|c|}{ Médias de tensão de ruptura (Mpa) } \\
\hline FATOR DE VARIAÇÃO & TENSÃO (Mpa) \\
\hline Argônio & 44,8 \\
\hline Lâmpada & 40 \\
\hline LED 60 & 40,9 \\
\hline LED 40 & 43,4 \\
\hline
\end{tabular}

Através destes dados, verificamos que os valores obtidos com a lâmpada convencional, com o dispositivo LED em exposição de $40 \mathrm{~s}$ e $60 \mathrm{~s}$ apresentaram valores equivalentes de tensão de ruptura. O laser de argônio apresentou um discret aumento na resistência à ruptura pelo ensaio de tração diametral.

Quando o fator de variação foi o meio de armazenagem os valores médios de tensão obtidos estão mostrados na tabela 5.11. O valor crítico calculado para estas interações foi de 4,6.

Tabela 5.11: Médias de tensão de ruptura em função do meio de armazenagem.

\begin{tabular}{|c|c|}
\hline \multicolumn{2}{|c|}{ Médias de tensão de ruptura (Mpa) } \\
\hline FATOR DE VARIAÇÃO & TENSÃO (Mpa) \\
\hline Controle & 55,1 \\
\hline Água & 46,1 \\
\hline Álcool 50\% & 35,3 \\
\hline Ácido Acético & 36,0 \\
\hline Ácido Propiônico & 38,8 \\
\hline
\end{tabular}


Dispositivos LED para polimerização de resinas compostas dentais: comparação com outras fontes de luz

Capítulo V - Variação de propriedades mecânicas das resinas compostas com a exposição a agentes químicos e análise em microscopia eletrônica de varredura

Os dados indicados na tabela mostraram que os meios químicos de imersão determinaram uma redução na resistência à tração diametral estatisticamente significante. Os meios mais agressivos a esta propriedade foram o álcool $50 \%$, o ácido acético e o ácido propiônico apresentando redução dos valores de tensão de ruptura, em torno de $30 \%$ com relação ao grupo controle.

Pode-se concluir que os meios de imersão afetam de forma notável a propriedade de resistência à ruptura. A razão disso advém, provavelmente, da incorporação química dos agentes, fragilizando a resina composta. No entanto, dentro de cada grupo de imersão, os resultados mostram-se muito próximos, indicando que, neste aspecto, as várias fontes de luz utilizadas são completamente equivalentes. A água destilada parece ser o meio que menos afeta a tensão diametral, mostrando que, além de incorporação de moléculas poderão estar ocorrendo outros fenômenos químicos. 


\section{Análise Micromorfológica por Microscopia Eletrônica de Varredura}

Os fragmentos resgatados no ensaio de tração diametral foram analisados com auxílio de microscópio eletrônico de varredura em magnificações de $15 \mathrm{X}$ e $2000 \mathrm{X}$ de todos os grupos submetidos ao ensaio de tração diametral.

Pelas morfologias macroscópicas (aumento de $15 \mathrm{X}$ ) das fraturas, podemos verificar que a característica comum encontrada na maioria dos fragmentos foi a possível propagação da trinca das bordas em direção ao centro, onde aparece uma saliência evidenciando a região de encontro das trincas e a ruptura completa do espécime (Figuras 5.13 e 5.14).

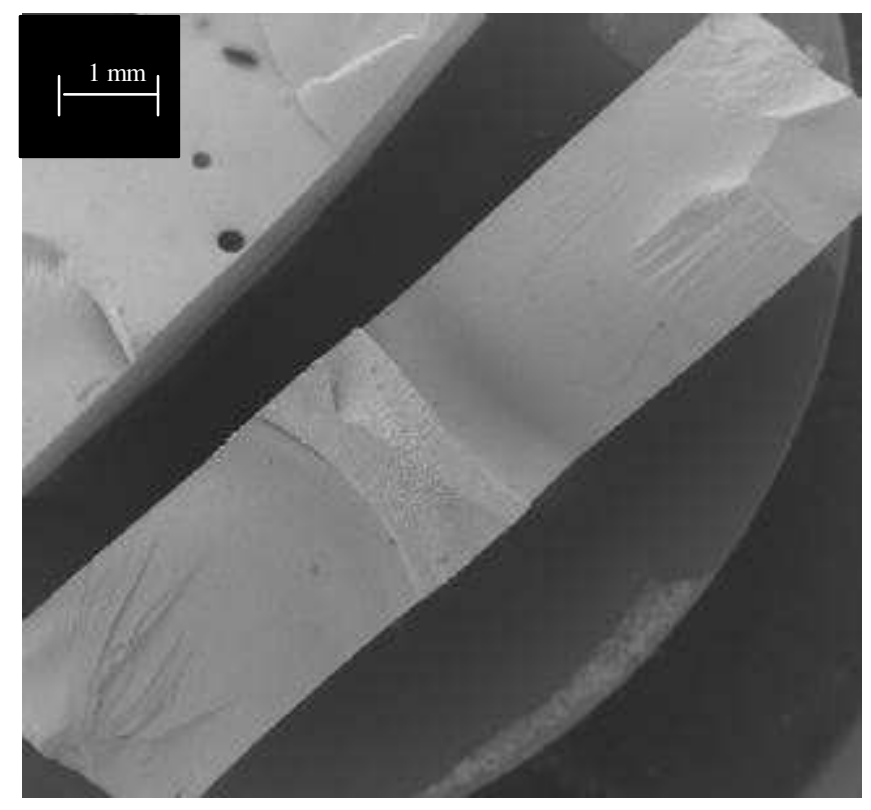

Figura 5.13 - Fotografia do fragmento polimerizado com o dispositivo LED em exposição de 60 segundos, em aumento de $15 \mathrm{x}$. 


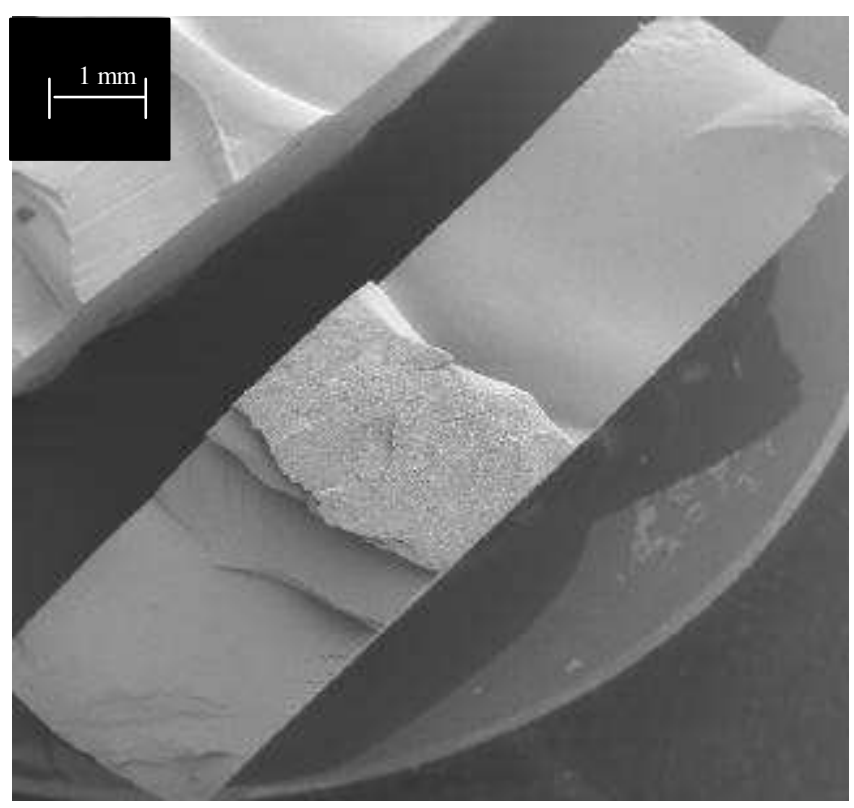

Figura 5.14 - Fotografia do fragmento polimerizado com o dispositivo LED em exposição de 60 segundos, armazenado em álcool $50 \%$, em aumento de 15 x.

Nas eletromicrografias de maior aumento, mostradas nas figuras 5.15, 5.16, 5.17 e 5.18, verificamos que a maioria das fraturas ocorreu de maneira semelhante independentemente da fonte de luz utilizada para polimerizar o espécime ou do meio de armazenagem a que foi submetido.

A principal característica encontrada é a presença de partículas cerâmicas expostas e locais que provavelmente as alojavam antes da fratura, em superfície relativamente plana. Estas evidências nos levam acreditar em uma fratura predominantemente frágil, em que a trinca se propaga pela região de menor resistência do material, neste caso, a própria matriz orgânica ou no agente silano que faz a união matriz polimérica - partícula cerâmica. 

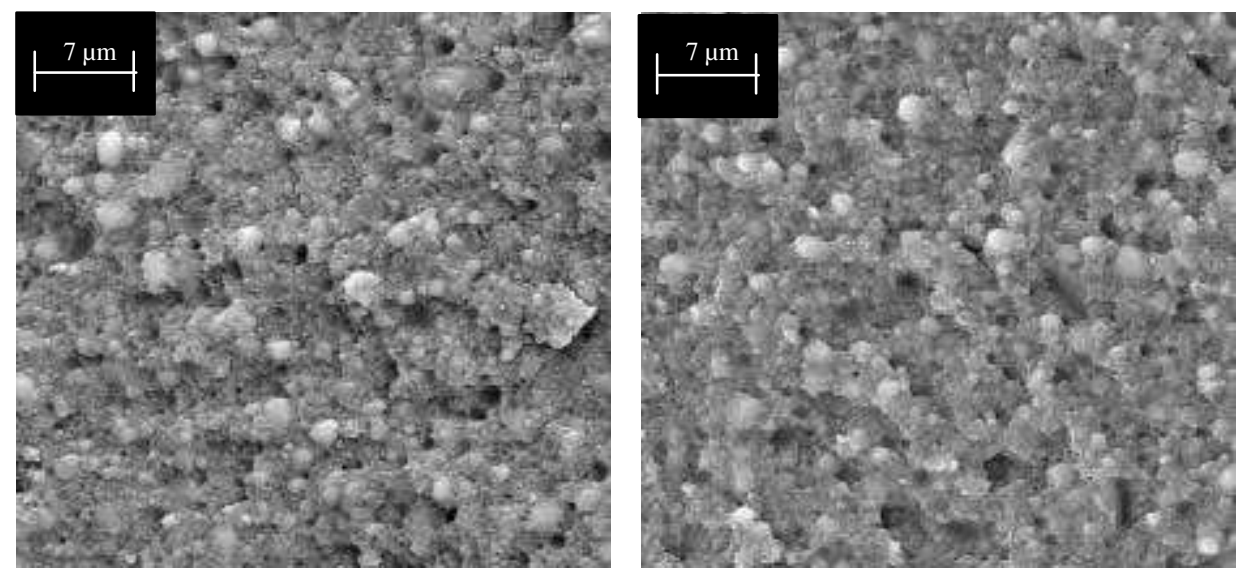

Figura 5.15 - Fotografia do fragmento polimerizado com o dispositivo LED em exposição de 60 segundos, grupo controle, em aumento de $2000 \mathrm{x}$.

Figura 5.16 - Fotografia do fragmento polimerizado com o dispositivo LED em exposição de 60 segundos, armazenado em álcool $50 \%$, em aumento de $2000 \mathrm{x}$.
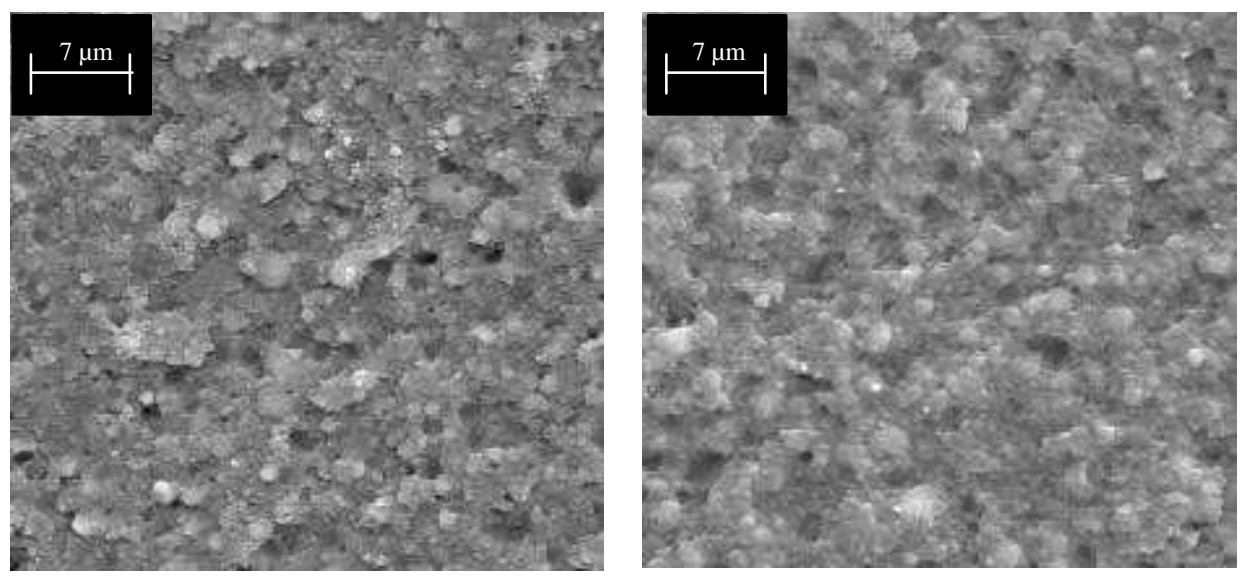

Figura 5.17 - Fotografia do fragmento polimerizado com o laser de argônio, grupo controle, em aumento de $2000 \mathrm{x}$.

Figura 5.18 - Fotografia do fragmento polimerizado com o aparelho convencional, armazenado em ácido acético, em aumento de $2000 \mathrm{x}$. 


\title{
Disposit ivos LED para polimerização de
}

\section{resinas compostas dent ais: comparação}

\author{
com out ras f ont es de luz.
}

Capítulo VII: Discussões, conclusões e sugestões para trabalhos futuros 


\section{DISCUSSÕES GERAIS}

Através dos experimentos relatados nesta dissertação, pudemos concluir que o dispositivo à base de LEDs azuis é capaz de polimerizar resinas compostas de diferentes espessuras, de forma equivalente ao aparelho convencional, se os tempos de exposição recomendados forem obedecidos.

$\mathrm{Na}$ análise térmica proposta para verificação da variação de temperatura pulpar durante a irradiação das fontes de luz para polimerização, constatamos que o dispositivo à base de LEDs pode ser utilizado por longos períodos de irradiação ininterruptamente, pois praticamente não altera a temperatura pulpar normal. Além disso, a variação térmica durante a irradiação com o aparelho convencional ou o laser de argônio pode ser mais um fator que contribui para a sensibilidade relatada pelos pacientes, após restaurações extensas de resinas compostas. As conseqüências do sobreaquecimento, ocorrido com o dispositivo convencional e o laser de argônio na restauração, coloca o dispositivo à base de LEDs em vantagem quando comparado às demais fontes. Além disso, as medidas de espectro de emissão e microdureza mostram que o aproveitamento energético dos LEDs para a polimerização de resinas compostas dentais é muito superior.

Os experimentos de determinação da variação das propriedades mecânicas após imersão em agentes químicos mostraram que a estabilidade físico- química da resina composta, adquirida com a polimerização através do dispositivo à base de LEDs, apresenta-se praticamente equivalente a lâmpada convencional. Com isto, podemos concluir que a fração polimerizada é adequada e não ocorrem grandes defeitos físico- químicos. De fato, a sutil superioridade de resistência das resinas 
compostas, curadas com a lâmpada ou o laser, pode advir do aquecimento causado, funcionando como ativador térmico do processo.

A análise das fraturas não mostra alterações consideráveis entre as várias fontes utilizadas, indicando que, estruturalmente, as resinas compostas polimerizadas com as fontes estudadas são bastante equivalentes. 


\section{CONCLUSÕES ESPECÍFICAS}

- Ensaio de Microdureza Vickers - o dispositivo LED é capaz de polimerizar a resina composta Z-100 (3M do Brasil), possibilitando uma microdureza Vickers semelhante ao dispositivo convencional, nas espessuras de $0,7 \mathrm{~mm}$ e $2,0 \mathrm{~mm}$, no entanto com aumento no tempo de irradiação da amostra;

- Análise Térmica - O dispositivo à base de LEDS apresenta a vantagem de não modificar a temperatura, no interior da polpa de terceiros molares humanos, evitando danos térmicos;

- Redução das Propriedades X Agentes Químicos - Os meios de imersão reduzem as propriedades de microdureza e resistência à tração diametral, independentemente da fonte de luz utilizada. Em cada meio de imersão houve uma compatbilidade entre o dispositivo à base de LEDs e o aparelho convencional e o laser de argônio apresentou-se ligeiramente superior. Na microscopia eletrônica de varredura, constatamos, na grande maioria dos espécimes, fraturas na matriz polimérica (região interpartículas) ou entre a matriz polimérica e as partículas cerâmicas. 
Dispositivos LED para polimerização de resinas compostas dentais: comparação com outras fontes de luz. Capítulo VI- Discussões, Conclusões e sugestões para trabalhos futuros

\section{CONCLUSÃO GERAL}

O dispositivo à base de LEDs azuis mostrou-se viável para a finalidade de polimerização de resinas compostas dentais. 


\section{SUGESTÕES PARA TRABALHOS FUTUROS}

Apresentamos como sugestão para trabalhos futuros:

- O estudo de outras propriedades químicas e mecânicas das resinas compostas polimerizadas com o dispositivo à base de LEDs;

- O estudo das propriedades químicas e mecânicas com variadas marcas de resina composta, variando o conteúdo de partículas cerâmicas, as cores e utilizando materiais com cura através da luz que apresentem diferentes fotoiniciadores;

- O estudo detalhado da degradação química e descoloração interna das resinas compostas em função do grau de polimerização;

- Estudo da penetração da luz em função da espessura de tecido dental e material cerâmico com o dispositivo de LED para a verificar a viabilidade do uso desta fonte de luz para polimerização em cimentações utilizando material de fotopolimerizável ou de dupla presa;

- O estudo in vivo da sensibilidade após restauração de resina composta comparando diversas fontes de luz. 


\section{BIBLIOGRAFIA}

1. ANIC, I et al "In vitro pulp chamber temperature rises associated with the argon laser polymerization of composite resin" Lasers in Surgery and Medicine 19:438444, 1996

2. ANUSAVICE K.J., SÖDERHOLM, K.J.M., GROSSMAN D.G.: "Implications of amalgam and ceramic degradation in the oral enviroment" MRS Bulletin. Pittsburgh: Mater Res Soc, 1993.

3. ARIKAWA et al. Deterioration of Mechanical properties of composites resins. Dent Mater, 1995; 14(1): 78-83.

4. ASMUSSEN, E.; PEUTZFELDT, A. Influence of UEDMA, BisGMA and TEGDMA on selected mechanical properties of experimental resin composite. Dent. Materials, 1998; 14: 51-6.

5. BARGHI, N., BERRY, T., HATTON, C. Evaluating intensity output of curing lights in private dental offices. JADA, 1994; Jul: 992-996.

6. BRAEM, M.; LAMBRECHTS, P.; VANHERLE, G. Clinical relevance of laboratory fadigue studies. J. Dent, 1994; 22: 97-102. 
7. BRENNEISE, CV and BLANKENAU, RJ "Response of associated oral soft tissue when exposed to argon laser during polymerization of dental resins" Lasers in Surgery and Medicine 20:467-472, 1997.

8. CALAIS J.G., SÖDERHOLM, K.J.: "Influence of filler type and water exposure on flexural strength of experimental composite resins" J. Dent. Res 67(5):836840, 1988.

9. CARVALHO, R.M. et al. A Review of polymerization contraction: the influence of stress development versus stress relief. Operative Dentistry, 1996; 21: 17-24.

10. CAUGHMAN W.F., RUEGGEBERG, F. A., CURTIR JR., J.W. "Clinical guidelines for photocuring restorative resins" - J. Am. Dent. Assoc., 1995; 126 : $1280-6$.

11. CAYLESS M.A., MARSDEN A.M. "Tungsten halogen lamps" In Lamps and lighting 3rd ed. 169-182 London Edwards Arnold Ltd, 1983.

12. COBB, D.S., VARGAS, M.A., RUNDLE, T. Physical properties of composite cured with conventional light or argon laser. Am J Dent, 1996; 9: 199-202.

13. COBB, DS; DEDERICH, DN; GARDNER, TV "In vitro temperature change at the dentin/pulpal interface by using conventional visible light versus argon laser" Lasers in Surgery and Medicine, 26: 386-397, 2000 
14. DAVIDSON, C. L. AND FEILZER, A. J. Polymerization shrinkage and polymerization shrinkage stress in polymer-based restorative. J. Dent. 1997; 25: 435-440.

15. DAVIDSON-KABAN, S. S. et al "The effect of curing light variation on bulk curing and wall-to-wall quality of two types and various shades of resin composites" Dent Mater, 1997; 13:344-352.

16. DRUMMOND, J.L. et al. Fracture properties of aged and post-processed dental composites. Eur. J. Oral Sci., 1998; 106: 661-6.

17. FEILZER, A. J. et al " Influence of light intensity on polymerization shrinkage and integrity of restorations" - Eur. J. Oral Sci., 1995; 103: 322-6.

18. FERRACANE, J.L., CODON J.R. Rate of elution of leachable components from composite. Dent Mater, 1992; 6(4):282-87.

19. FERRACANE, J. L. et al. In vitro aging dental composites in water - effect on degree of convertion, filler volume, and filler matrix coupling. Int. J. Biomed. Mater. Res., 1998; 42: 465-72.

20. FERRACANE, J.; MARKER, V.A. Solvent degradation and reduced fracture toughness in aged composites. J. Dent. Res, 1992; 71: 13-9. 
21. FUJIBAYASHI, K, et al. "Newly developed curing unit using blue light-emitting diodes.” Dentistry in Japan, 34:49-53, march, 1998.

22. HANSEN, E.K., ASMUSSEN, E. Correlation between depth of cure and temperature rise of a light-activated resin. Scand J. Dent. Res, 1993; 101: 176-9.

23. HARRINGTON, E. and WILSON, H.J. Determination of radiation energy emitted by light activation units. J. Oral Rehab, 1995: 22: 377-85.

24. IMAZATO S. et al. "Relationship between the degree of conversion and internal discoloration of light-activated composite" - Dent Mater J 14(1):23-30, 1995.

25. JANDT et al. Depth of cure and compressive strength of dental composites cured with blue light emitting diodes (LEDs). Dent Mater, 2000; 16: 41-47.

26. KORAN P. and KURSCHNER R. “ Effect of sequencial versus continuous irradiation of a light cured resin composite on shrinkage, viscosity, adhesion, and degree of polymerization" - Am J Dent 10: 17-22, 1998.

27. KURACHI, $\mathrm{C}$ et al "Human teeth exposed to argon laser irradiation: determination of power-time-temperature working conditions" J Clin Laser Medicine \& Surgery 17 (6):255-259, 1999. 
28. KURACHI, C. Estudo comparativo do laser, do LED azul e da lâmpada convencional no processo de polimerização da resina composta dental. São Carlos, 2000, 82p. Dissertação (mestrado) - Interunidades - Universidade de São Paulo.

29. KURACHI, $\mathrm{C}$ et al. Hardness evaluation of a dental composite polymerised with experimental LED-based devices. Dent Mater, 2000; 17:309-15.

30. LEE, S.Y. et al. "Leached components from dental composites in oral simulating fluids and the resultant composite strengths" - J Oral Rehabilitation 25: 575-588, 1998.

31. LOSCHE, G. M. " Marginal Adaptation of Class II Composite fillings: Guided Polymerization vs Reduced Light intensity. “J. Adhesive Dent,1999; 1: 31-9.

32. MCKINNEY J.E., WU W.: "Chemical softening and wear of dental composites." J Dent Res 64: 1326-1331, 1985.

33. MEHL et al. Physical properties and gap formation of light-cured composites with and without 'softstart-polymerization'. J. Dent. 1997; 25: 321-330.

34. MENINGA, A et al. Pulsed blue laser curing of hybrid composite resins. Biomaterials, 1997; 18: 1349-54. 
35. MILLS, R.W., JANDT, K.D., ASHWORTH, S.H. "Dental composite depth of cure with halogen and blue light emitting diode technology." Brit. Dent. J. 186:388-91, 1999.

36. NOMOTO, R. Effect of light wavelength on polymerization of light-cured resins. Dent Mater Journal, 1997; 16(1):60-73.

37. PEUTZFELDT, A. Resin composites in dentistry: the monomer systems. Eur J Oral Sci 1997; 105: 97-116

38. PIRES et. al. - "Effects of curing tip distance on light intensity and composite resin microhardness" Quintessence International, 1993; 24(7):517-521.

39. POWELL, GL; ANDERSON, JR; BLANKENAU, RJ “Laser and curing light induced in vitro pulpal temperature changes" J Clin Laser Medicine \& Surgery, 17(1):3-5, 1999.

40. RUEGGEBERG, F.A., JORDAN, D.M. "Effect of light tip distance on polymerization of resin composite.” - Int. J. Prosthodont , 1993; 6: 364-70.

41. SAKAGUSHI R.L., BERGE H.X. "Reduced light energy density decreases postgel contraction while maintaining degree of conversion in composites" - Journal of Dentistry, 1998; 26: 695-700. 
42. SHIN M.A. and DRUMMOND J.L.: "Evaluation of chemical and mechanical properties of dental composites" J. Biomed Mater Res (Appl Biomater) 48:540$545,1999$.

43. SKINNER, E.W. "Skinner materiais dentários" Guanabara Koogan, 1996, 9 a'. Ed., 334 p, Rio de Janeiro.

44. SÖDERHOLM, K.J.: "Degradation of glass fillers in experimental composites" J. Dent. Res 60(11):1867-1875, 1981

45. SÖDERHOLM, K.J.: "Leaking of fillers in dental composites" - J. Dent. Res 62(2):126-130, 1983.

46. STAHL, F., et al. Light-emitting diode (LED) polymerization of dental composites: flexural properties and polymerization potential. Biomaterials, 2000; 21: $1379-85$.

47. TAIRA, M. et al. "Analysis of photo-initiators in visible light cured dental composite resins”. J. Dent. Res, 1988; 67: 24-8.

48. TURBINO, M.L. et al. "Photopolymerized resins: surface hardness variation in relation to time of polymerization and setting." Braz. Dent. J., 1992: 87-94. 
49. VARGAS et al. "Polymerization of composites resins: Argon laser vs Conventional Light" Operative Dentistry, 23:87-93, 1998

50. WHITTERS, C.J., GIRKIN, J.M., CAREY, J.J. "Curing of dental composites by use of InGaN light-emitting diodes." Optics Letters 24(1):67-68, 1999.

51. YANAGISAWA, T. Estimation of degradation of InGaN / AlGaN blue lightemitting diodes. Microelectron. Reliab. 1997; 34 (8): 1239-41.

52. YEARN, J.A. Factor affecting cure of visible light activated composites. Int Dent Journal, 1985; 35:218-25.

53. ZACH, L and COHEN, G "Pulp response to externally applied heat." Oral Surg Oral Med Oral Pathol 19:515-530, 1965. 


\section{APÊNDICE A}

\section{$\underline{\text { Breve revisão da literatura sobre laser de argônio e dispositivos à base de }}$}

\section{LEDs}

VARGAS e colaboradores, em 1998, verificaram a microdureza de resina composta híbrida (TPH $<$ Dentsply $>$ ) e de micropartículas (Silux Plus $<3 \mathrm{M}>$ ) curadas com luz halógena convencional por 40 segundos e com laser de argônio em tempos de 10,20 e 30 segundos e não observaram diferença significante estatisticamente. Por outro lado, o alto custo do laser de argônio para cura de resinas compostas torna a relação custo-benefício economicamente inviável para a utilização em consultórios odontológicos. [49]

MENINGA e colaboladores, utilizaram um laser de excimer pulsado, operando na linha de $468 \mathrm{~nm}$, para a polimerização de resinas compostas híbridas, comparando com o dispositivo para polimerização convencional em relação a propriedade de microdureza na superfície irradiada e na superfície oposta à irradiação em espécimes de 3,0 mm de espessura. Os resultados demonstraram que os valores de microdureza praticamente não modificavam no topo e base de espécimes polimerizados com o laser, enquanto que, para o apareho convencional apresentou uma redução na microdureza estatisticamente significante. [34]

COBB e colaboradores estudaram, em 1996, as propriedades físicas de resistência à tração diametral, resistência à compressão e resistência flexural de resinas compostas híbridas e de micropartículas polimerizadas por laser de argônio por 10 segundos e 20 segundos e com um aparelho convencional por 40 segundos. Os resultados 
mostraram que as fontes de luz utilizadas nos diferentes tempos de exposição não afetaram significativamente nenhuma das propriedades físicas para a resina composta Herculite XRV (Kerr, MI, USA). Para a resina Durafill (Kulzer, German), a propriedade de resistência à tração diametral não foi afetada pela fonte de luz utilizada ou pelo período de exposição. Menores valores de resistência à flexão foram encontrados quando os corpos de prova da resina composta Durafill foram irradiados por 10 segundos com o laser de argônio em comparação com a irradiação por 20 segundos com o laser de argônio ou 40 segundos com o dispositivo convencional. Além disso, valores significantemente menores de resistência à compressão foram encontrados para a resina Durafill quando polimerizados com o laser de argônio por 10 segundos quando comparados com o aparelho de cura convencional. [12]

FUJIBAYASHI e colaboradores, em 1998, verificaram a possibilidade de uso de diodos emissores de luz (LED) azuis como alternativa para o aparelho de polimerização convencional. Os pesquisadores utilizaram dois arranjos de 61 LEDs, o primeiro conjunto apresentava pico de emissão em 444nm (LED1) e o segundo arranjo apresentava pico de emissão em 466nm (LED2). A profundidade de polimerização foi mensurada de acordo com a norma ISO4049 e observou-se uma maior profundidade de polimerização para o arranjo de LED-2. [21]

WHITTERS e colaboradores, em 1999, utilizaram um arranjo de seis LEDs azuis e compararam com o aparelho de polimerização convencional na polimerização de três diferentes resinas compostas comerciais: Tetric A3 e Compoglass A3 (Ivoclar, Vivadent, Lichtenstein) e Z100 A3.5 (3M dental Products, MI, USA). Os autores determinaram valores de microdureza Knoop para o dispositivo convencional 
e para o arranjo de LEDs alimentados com duas diferentes intensidades de corrente: 40 e $60 \mathrm{~mA}$. Ambos os dispositivos foram ajustados para um período de irradiação de 60 segundos. Os resultados demonstraram pequenas diferenças na dureza do material quando utilizados o aparelho convencional e o dispositivo LED de maior potência. Os autores verificaram também a contração linear de polimerização e verificaram que este fator independe da fonte de luz utilizada. [50]

JANDT e colaboradores, em 2000, verificaram a profundidade de polimerização e a resistência à compressão de espécimes de resina composta polimerizados com o dispositivo de polimerização convencional e um arranjo de 27 LEDs. O aparelho convencional apresentava intensidade de $755 \mathrm{~mW} / \mathrm{cm}^{2}$ e o arranjo de LEDs $350 \mathrm{~mW} / \mathrm{cm}^{2}$. Os resultados demonstraram que o dispositivo convencional apresentou uma profundidade de polimerização significantemente maior que o arranjo de LEDs, no entanto, ambos os aparelhos apresentaram profundidade de polimerização acima do exigido pelo fabricante e pela norma ISO 4049. A resistência à compressão dos espécimes apresentou-se igual, em condições laboratoriais, para ambos os dispositivos. [25]

STAHL e colaboradores, em 2000, verificaram as propriedades flexurais obtidas em três diferentes compósitos em três matizes diferentes, polimerizadas com a unidade de cura LED e com a unidade de cura halógena. O dispositivo LED deste estudo apresenta arranjo de 27 LEDs (Nichia Chemical Industries Ltd, Anan, Japan) com intensidade de $350 \mathrm{~mW} / \mathrm{cm}^{2}$ e a unidade halógena (Spectrum $201 \mathrm{R}$, Dentsply, DeTrey, German) apresentou intensidade de $755 \mathrm{~mW} / \mathrm{cm}^{2}$. Os autores determinaram uma igualdade estatística nos resultados da resistência e módulo flexural mesmo com o dispositivo à base de LED apresentando menos da metade da intensidade. [46] 


\section{APÊNDICE B}

Apresentamos a evolução dos dispositivos à base de LEDs, desde o dispositivo experimental utilizado neste trabalho (figura 1), passando por um protótipo à bateria (figura 2) e culminando em um dispositivo comercial (figura 3) que utilizou este trabalho de mestrado para a sua montagem e fundamentação científica.

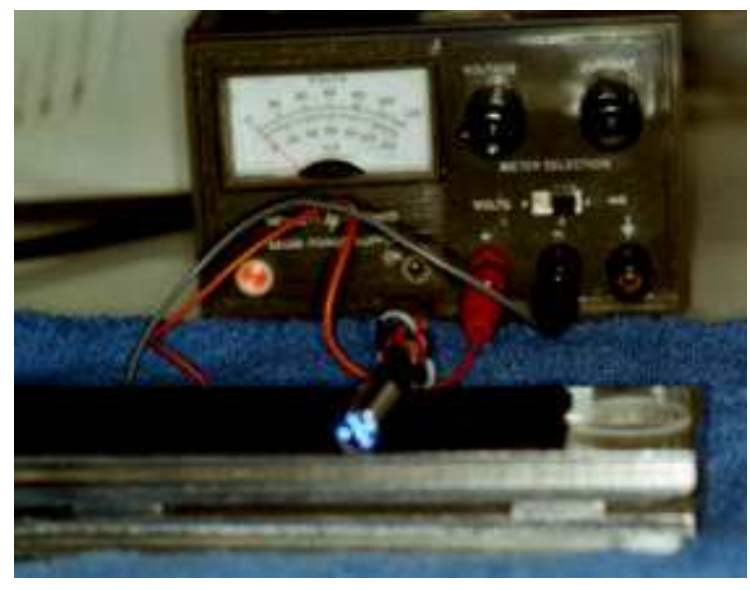

Figura 1 - Dispositivo experimental

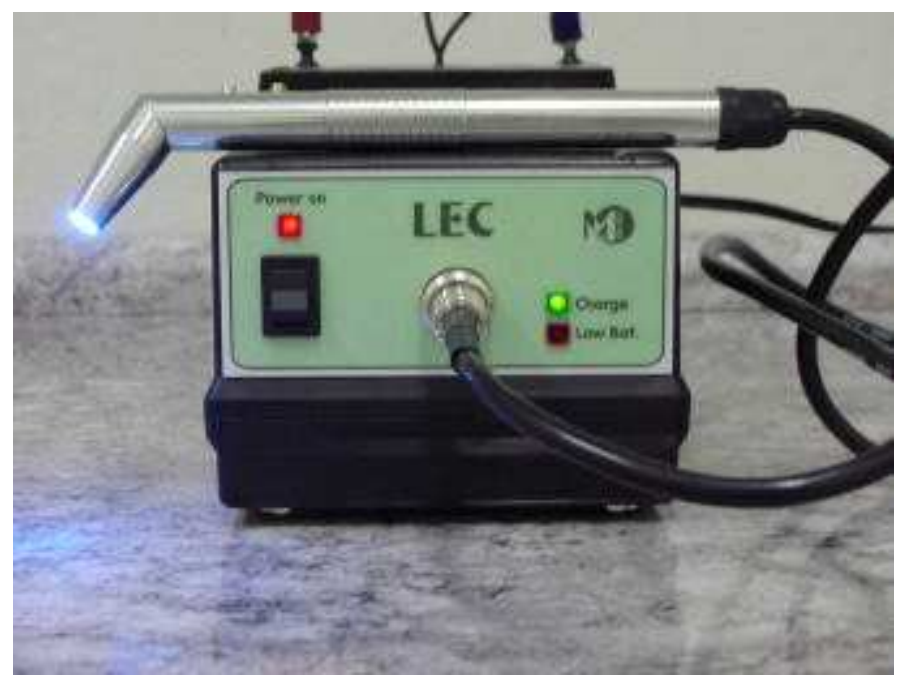

Figura 2 - Dispositivo à bateria 


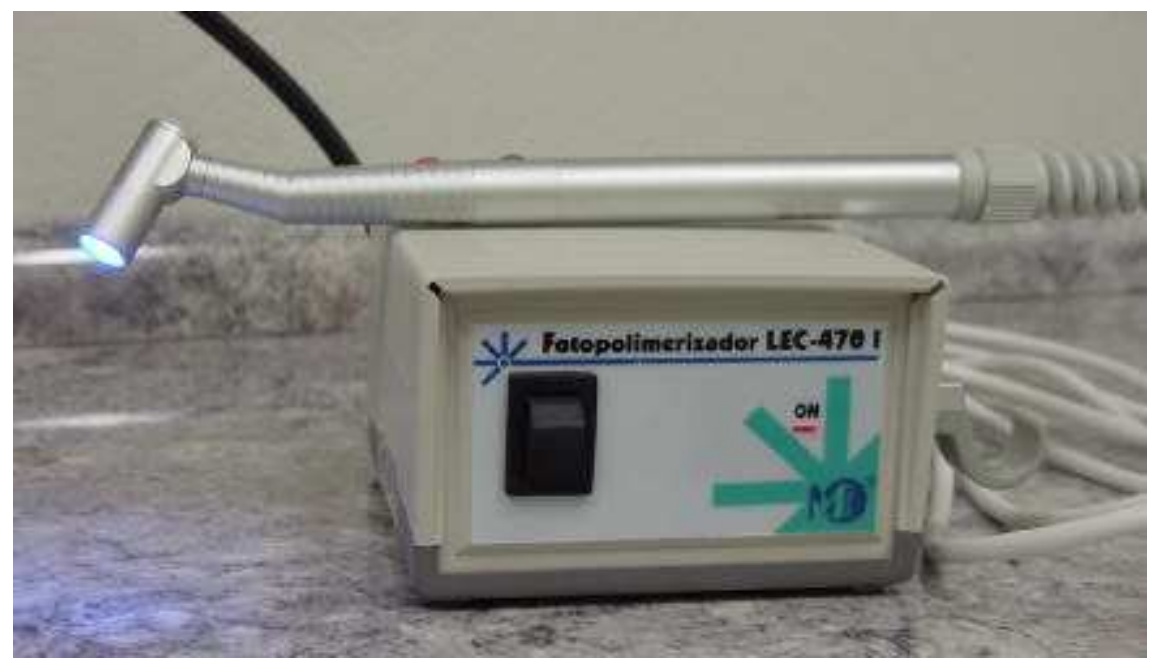

Figura 3 - Dispositivo comercial da empresa M\&M Optics

(São Carlos, Brasil). 